\title{
Radiocarbon
}

1984

\section{RADIOCARBON DATING IN THE SOUTHERN LEVANT}

\author{
JAMES M WEINSTEIN
}

Department of Classics, Cornell University, Ithaca, New York 14853

INTRODUCTION

Radiocarbon dating provides the principal chronometric data for the Middle and Upper Palaeolithic, Epipalaeolithic, and Chalcolithic periods in the southern Levant. It is a secondary source of dating evidence for the Early Bronze age, when archaeological correlations with Syria and especially Egypt become available. For the Middle and Late Bronze age, Iron age, Persian, Hellenistic, Roman, and Byzantine periods, ${ }^{14} \mathrm{C}$ dating has only limited value because the technique is less precise than the normally available archaeologic and historic materials.

In recent years, there has been a proliferation of publications containing ${ }^{14} \mathrm{C}$ date lists for the southern Levant. Almost invariably, these lists have focused on the Neolithic and earlier materials (eg, Henry \& Servello, 1974; Bar-Yosef, 1981a, p 405; 1981b, p 566-567; Henry, 1983, p 104-105). Only one list (Henry \& Servello, 1974) offers an evaluation of the individual dates. The Chalcolithic period is devoid of any published date lists, and the Early Bronze age has but a single comprehensive corpus and interpretive study (Callaway \& Weinstein, 1977; see also Mellaart, 1979). For the period from ca $2200 \mathrm{BC}$ to the present, there are no compendia of dates and no analytical studies beyond those for a few individual sites.

Because interest in the ${ }^{14} \mathrm{C}$ data has been focused on the earliest periods, general surveys of the role of ${ }^{14} \mathrm{C}$ in the archaeology and history of this region and systematic studies of the problems that Palestinian archaeologists encounter in utilizing this technique are lacking. As a basis for such future investigations, this paper will (1) present a corpus of ${ }^{14} \mathrm{C}$ dates from the southern Levant, and (2) furnish a brief examination of the chronologic and archaeologic import of the data.

\section{TABLE OF RADIOCARBON DATES}

The accompanying table contains 474 dates from Israel, Jordan, the West Bank, Golan Heights, Gaza Strip, and Sinai. Three hundred assays $(63.3 \%$ of the total) have appeared in the date lists of Science, Radiocarbon (through the final issue for 1984), and "Radiocarbon Measurements: Comprehensive Index, 1950-1965"; $150(31.6 \%)$ derive from other sources, and $24(5.1 \%)$ are unpublished. Absent from the table is a "modern" date furnished by a fake antiquity (Mendenhall, 1971, p 99; cf Naveh, 1982, p 53-54). 


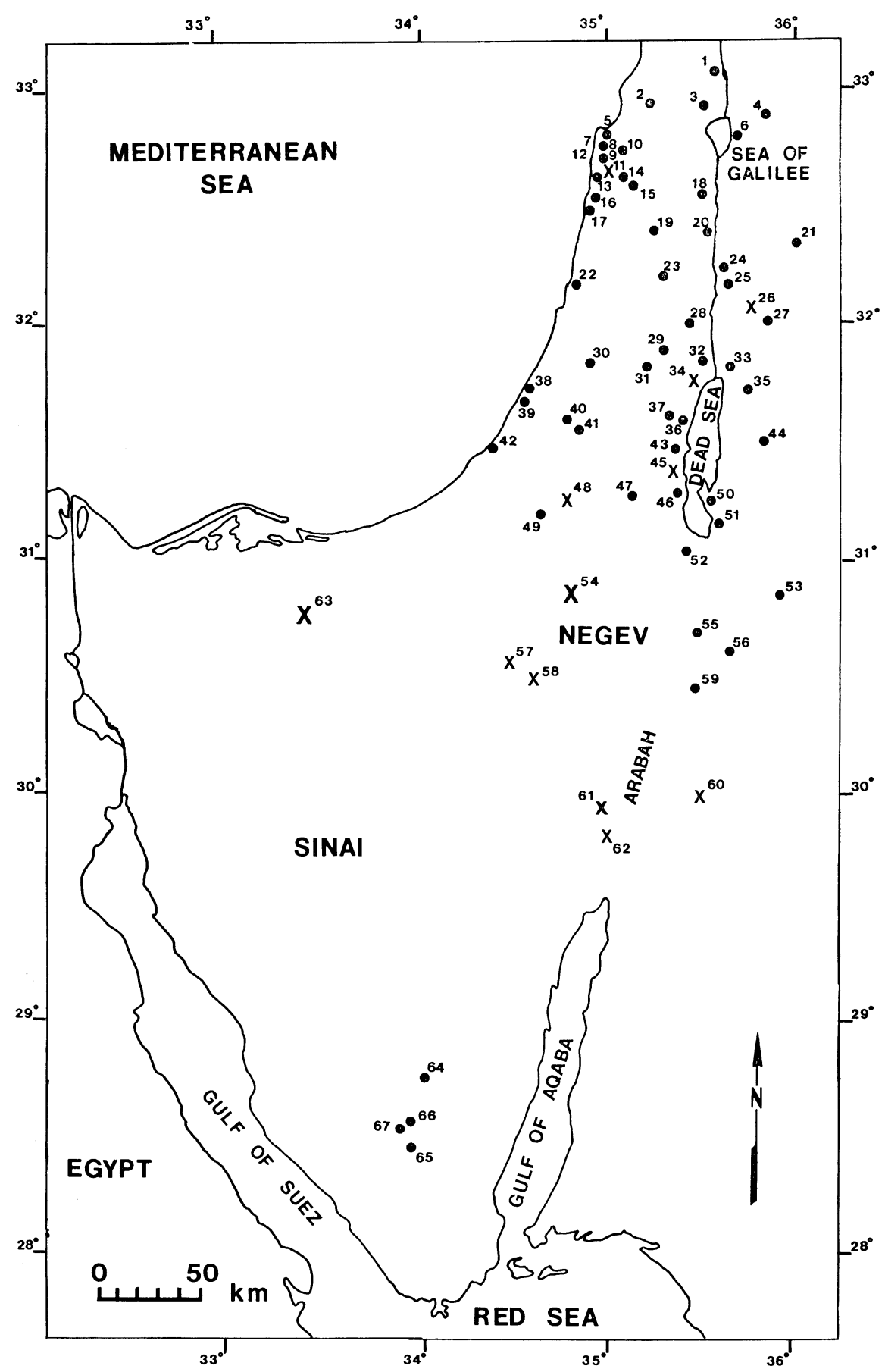


The dates are arranged by archaeologic period and, within each period, alphabetically by site. If a date could not be assigned to any period because of insufficient information or because the sample was misassociated, it has been relegated to a category entitled "Archaeological Period Unknown." For each entry, the corpus gives the provenience, material, 5568-year half-life BP and $\mathrm{BC} / \mathrm{AD}$ determinations, the $\delta^{13} \mathrm{C}$ measurement, calibrated date, laboratory number, and references. All of the sites are located on the map in figure 1.

Fig 1. Sites in the southern Levant represented by ${ }^{14} \mathrm{C}$ dates. A solid circle indicates an individual site. An " $x$ " indicates an area with two or more sites.

\begin{tabular}{|c|c|}
\hline 1. Eynan & 45. Nahal Mishmar: \\
\hline 2. Hayonim Cave and Terrace & Caves 1, 2 \\
\hline 3. Amud Cave & 46. Masada \\
\hline 4. Rasm Harbush & 47. Arad \\
\hline 5. Geula Cave & 48. Beersheba: \\
\hline 6. Fin Gev I & Bir es-Safadi \\
\hline 7. Sea bed near Kibbutz ha-Hotrim & Horvat Beter \\
\hline 8. Sefunim Cave and Terrace & 49. Shiqmim \\
\hline 9. Nahal Oren Terrace & 50. Bab edh-Dhra \\
\hline 10. Rakefet Cave & 51. Numeira \\
\hline 11. Carmel caves: & 52. Mazad Mazal \\
\hline El-Wad Cave and Terrace & 53. Wadi Hasa \\
\hline Tabun Cave & 54. Avdat/Aqev area: \\
\hline 12. Sea of Athlit & Boker A \\
\hline 13. Newe Yam & Boker BE \\
\hline 14. Tell Qiri & Boker Tachtit \\
\hline 15. Ein cl-Jarba & D5 \\
\hline 16. Kebara Cave & Dl01B \\
\hline 17. Caesarea & Ein Aqev (D31) \\
\hline 18. Munhata & Nahal Divshon \\
\hline 19. Dothan & Rosh Ein Mor (D15) \\
\hline 20. Tell Tsaf & 55. Jebel Khirbet en-Nahas \\
\hline 21. Tell er-Rumeith & 56. Wadi Feinan-Wadi Dana area \\
\hline 22. Tel Michal & 57. Kadesh Barnea: \\
\hline 23. Shechem & Kadesh Barnea 3 \\
\hline 24. Tell es-Sacidiyeh & Kadesh Barnea 8 \\
\hline 25. Deir ${ }^{c}$ Alla & Kadesh Barnea (no number) \\
\hline 26. Baq'ah Valley: & 58. Har Harif: \\
\hline Jebel al-Qesir & Abu Salem \\
\hline Khirbet Umm ad-Dananir & Rosh Horesha \\
\hline 27. Tell Siran & Har Harif G9 \\
\hline 28. Netiv Hagdud & 59. Beidha \\
\hline 29. $\mathrm{Ai}$ & 60. Wadi Judayid Basin: \\
\hline 30. Gezer & Wadi Judayid (J2) \\
\hline 31. Gibeon & Jebel Queisa (J24) \\
\hline 32. Jericho & 61. Uvda Valley: \\
\hline 33. 'Teleilat el-Ghassul & Nahal Issaron \\
\hline 34. Qumran: & Site 6 \\
\hline Qumran (settlement) & 62. Timna: \\
\hline Ain Feshka: Cave IQ & Sites 2, 30, 39, 200, 212, F2 \\
\hline 35. Rujm Mekhayyat & Wadi Amram \\
\hline 36. Wadi Murabba ${ }^{c}$ at & 63. Gebel Maghara: \\
\hline 37. El-Khiam & Ain Abu Rugum I \\
\hline 38. Nizzanim & Lagama IIID, VII, VIII \\
\hline 39. Ashkelon & Mushabi I, V, XIV, XVI, XVII, \\
\hline 40. Tell Areini & XVIII, 103 \\
\hline 41. Iachish & 64. Wadi Tbeik \\
\hline 42. Tell el-c Ajjul & 65. Monastery of St Catherine \\
\hline 43. Nahal Hever & 66. Abu Madi \\
\hline 44. Dibon & 67. Ujrat el-Mehed \\
\hline
\end{tabular}


The site and context of a sample follow the most recent archaeologic attribution, which frequently is not the one cited in a date list. On the other hand, the identification of the sample material (Column 2) follows the published or unpublished sources precisely. If a published date contains no notation as to the nature of the sample, but the material could be determined with some certainty, the identification is written within parentheses. Quotation marks in the "Material" column call attention to redated samples. The "Refs and Remarks" column also indicates redated samples as well as the application of different pretreatments to any of these samples.

In the third column, an adjustment has been made in computing the BC date whenever a primary publication has used a year other than AD 1950 as the datum year. In such cases, the author has disregarded the published BC date and retained the вP figure alone for subsequent calculations. This procedure is predicated on an assumption, which admittedly may not be justified in every case, that the published BP figure comes from the ${ }^{14} \mathrm{C}$ laboratory, while the $\mathrm{BC}$ date was computed by the excavator, who evidently used as the datum year either the year in which he made his calculations or the year in which the laboratory processed the sample. The following 19 entries have required adjustments:

I-616: AD 1961 used as datum year by Aharoni (1962, p 190).

I-285; I-353: AD 1961 used as datum year by Bar-Adon (1980, p 199).

I-1819: AD 1963 used as datum year by Bar-Adon (1980, p 199).

I-? (four dates): AD 1964 used as datum year by Aharoni (1967, p 238).

BONN-2356, -2357, $-2359,-2360$ to -2363 : AD 1975 used as datum year by

Conrad and Rothenberg (1980, p 179).

GX-1718: AD 1970 used as datum year by Seger $(1972, p$ 31).

MP-?: AD 1957 used as datum year by Reed (1957, p 8, n 8) and Winnett and Reed (1964, p 49).

L-365: AD 1956 used as datum year by Free (1957, p 37).

RT-? (Crusader period date): AD 1973 used as datum year by Kedar and Kaufman (1975, p 37-38).

The fourth column present the "CRD- $\sigma$ " corrections for the conventional ${ }^{14} \mathrm{C}$ dates with BP values between 7230 and 940 years. The unpublished CRD- $\sigma \sigma$ table employs the same data set and statistical methods as the CRD-2 $\sigma$ table (Klein et al, 1982). For the few samples with BP determinations less than 940 years, Stuiver's (1982) high-precision calibration curve has been used.

The laboratory code and sample number appear in Column 5. When a sample number was not available, the laboratory code is followed by a question mark. The last column in the table supplies publication references, information on the provider(s) of unpublished data, miscellaneous archaeologic comments, identification of undersized samples, notes on which samples were re-runs, and notations on any publication errors. References are cited according to a modified social science system: the author's name(s) comes first, then the date of publication and page reference $(\mathrm{s}) .{ }^{14} \mathrm{C}$ dates published in Radiocarbon are cited as " $\mathrm{R}$," followed 
by the year of publication, volume number, and page(s). The citation "RMCI" refers to "Radiocarbon Measurements: Comprehensive Index, 1950-1965."

The abbreviations listed in the Radiocarbon Style Guide (1984, v 26, p 157-158) are supplemented in the table as follows:

$$
\begin{array}{ll}
\text { ab_above } & \text { min-minimal } \\
\text { br_brick } & \text { n-note } \\
\text { bs_below surface } & \text { ph-phase } \\
\text { cent_-century } & \text { poss-possible, bly } \\
\text { ch-chamber } & \text { rm-room } \\
\text { col_column, s } & \text { sndg-sounding } \\
\text { conf-conflagration } & \text { st-stage } \\
\text { dest-destruction } & \text { str-stratum } \\
\text { fl-floor } & \text { tr-trench }
\end{array}
$$

\section{Palaeolithic period}

\section{THE RADIOCARBON DATA}

Radiocarbon dating has yielded mixed results in dating Palaeolithic remains in the southern Levant. The Lower Palaeolithic and much of the Middle Palaeolithic lie beyond the range of conventional ${ }^{14} \mathrm{C}$ dating systems, while many Middle and Upper Palaeolithic dates are either aberrant or only minimal values. Fortunately, there are several excellent groups of Upper Palaeolithic assays from southern Israel and northern Sinai.

Uranium series dates obtained from travertines in Zuttiyeh cave on the northwest side of the Sea of Galilee suggest that the Early Levantine Mousterian industry of the Middle Palaeolithic period stretches back to ca 90,000 to 100,000 years вP (Schwarcz et al, 1979; Schwarcz, Goldberg, \& Blackwell, 1980). The termination of the Middle Palaeolithic is dated by a combination of ${ }^{14} \mathrm{C}$ dates from Boker Tachtit in the central Negev highlands and uranium series dates from travertine deposits in nearby Nahal Mor. These indicate that the Middle Palaeolithic ended ca 47,000 to 45,000 years BP (Marks, 1981a, table I).

There are 49 Middle Palacolithic assays, associated either with caves in northern Israel (42 dates from Amud, Geula, Kebara, and Tabun caves) or open-air sites in the central Negev highlands (7 dates from Rosh Ein Mor and Boker Tachtit). Nearly all of the dates from Amud, Kebara, and Tabun caves are much too young, with those from the Amud and Kebara caves being extraordinarily low. These dates often show internal inconsistencies, eg, between LJ-2084 and -2090 from Tabun, or the inconsistent and stratigraphically inverted results from throughout the Kebara and Amud sequences. The small amount of carbon in the samples that were processed at the Hanover laboratory may have influenced the poor results obtained for the Middle and Upper Palaeolithic samples from Kebara cave (Schick \& Stekelis, 1977, p 135*). Other anomalous dates may be due to an unfavorable environment for ${ }^{14} \mathrm{C}$ samples in the deposits of these caves, eg, recent vegetal growth, groundwater as well as alternating layers of humus and calcium carbonate at Amud (cf Hamada, 1970), bat guano 
in El-Wad and Kebara caves, and the roof collapse and subsequent ingress of water at Tabun cave. Three ${ }^{14} \mathrm{C}$ assays from Tabun cave $(\mathrm{GrN}-7408$ to -7410) provide an approximate date of ca 50,000 years BP for a late stage of the Middle Palaeolithic period. Finally, GrN-4121 (40,050 \pm 1700 BC) from a Late Levantine Mousterian context at Geula cave looks somewhat too recent, based on the Boker Tachtit dates noted above.

In southern Israel, the 3 inconsistent dates from the Early Levantine Mousterian site of Rosh Ein Mor dates are only minimal values and, moreover, are much too recent based on the ${ }^{230} \mathrm{Th} /{ }^{234} \mathrm{U}$ dates from Nahal Aqev (Schwarcz et al, 1979; Marks, 1981a, p 288). On the other hand, 3 of the 4 Late Levantine Mousterian dates from Level 1 at Boker Tachtit and the uranium series dates from Nahal Mor are in good agreement (as noted above). Thus, the assays from Boker Tachtit and the 3 Tabun Cave dates are the only usable groups of Middle Palaeolithic dates in the southern Levant.

The Upper Palaeolithic period is represented by 29 dates. Although the sites of this period are now generally classified according to 1 of 2 industrial traditions, the Levantine Aurignacian or the Ahmarian (BelferCohen \& Bar-Yosef, 1981), the number of acceptable Upper Palaeolithic determinations is so small that it is wise to discuss them without regard for the industries they reflect.

The $7{ }^{14} \mathrm{C}$ dates from northern Israel are all aberrant. It has already been noted that the Kebara cave assays are inconsistent and much too young. The Hayonim and Sefunim cave dates are also too recent for the Upper Palaeolithic period, but here, the anomalous results may be due to misassociation of the samples (Belfer-Cohen \& Bar-Yosef, 1981, p 38).

The earliest Upper Palaeolithic assemblage in the south is represented by Level 4 at Boker Tachtit. It yielded a single date (SMU-579) that is too recent, probably because of contamination by humates (Marks, 1981b, p 345). The 3 dates from Area A at Boker include 2 with minimal values (SMU-187, -260), and 1 at 35,970 \pm 2810 BC (SMU-578). Levels I-III from the stratigraphically younger Area BE at Boker yielded a series of 7 dates, which (except for the outlier SMU-565) are nicely bracketed between ca 25,000 and 23,000 вс. In northern Sinai, Lagama VIII and VII have 3 dates between ca 32,000 to 29,000 вс, while Lagama IIID has a single date at ca 28,000 вс. Contemporary with the Lagama VIII and VII dates is Pta-2819 from an unpublished site at Kadesh Barnea in northeastern Sinai. Four of the 5 dates from the late Upper Palaeolithic site of Ein Aqev (D31) fit into the 16th millennium BC; only SMU-5 at $18,030 \pm 1200 \mathrm{BC}$ is evidently too early. Based on the overlapping of these 4 Ein Aqev determinations with Kebaran dates from Nahal Oren Terrace (Level IX) and Rakefet cave, the end of the Upper Palaeolithic period in the Negev may be contemporary with the early Epipalaeolithic period in the north (Marks, 1975, p 361).

\section{Epipalaeolithic period}

The principal industrial traditions of the Epipalaeolithic period are, in chronologic order, Kebaran, Geometric Kebaran A, and Natufian (Bar- 
Yosef, 1975; 1981a; Henry, 1983). At Nahal Oren Terrace, these industries occur in stratigraphic succession (Noy, Legge, \& Higgs, 1973).

The five Kebaran ${ }^{14} \mathrm{C}$ dates derive from three sites in northern Israel. These determinations range from $16,960 \pm 330 \mathrm{BC}(\mathrm{I}-6865)$ to $13,750 \pm$ 415 вс (GrN-5576). The small number and limited geographic distribution of the samples and the wide range of the dates give these assays an uncertain significance.

Geometric Kebaran A sites are more widely distributed than the Kebaran. However, the 13 assays for this industry all come from sites in the central and western Negev and northern Sinai. The 10 dates from Mushabi XIV (Level 2), XVI, XVII, and XVIII and Kadesh Barnea 8 fall within the 13 th and 12 th millennia $\mathrm{BC}$. The 3 remaining samples, from Site D5, were small and the measurements inconsistent. Based on the other Geometric Kebaran A assays, SMU-7 is too early at 16,890 \pm 680 вс. Tx-1121 may or may not be aberrant at 13,870 \pm 1730 BC, but the standard deviation is too large to inspire confidence in the midpoint.

A recently identified Epipalaeolithic industry in the Negev and northern Sinai is the Mushabian. Although the Mushabian has a lithic inventory distinct from that of the Geometric Kebaran A, the $9{ }^{14} \mathrm{C}$ dates belonging to the former complex show that it has significant temporal overlap with the latter. Indeed, the midpoints of 7 Geometric Kebaran $\mathrm{A}$ and 7 Mushabian dates fall within the 12th millennium, with the latter entity possibly continuing on into the early 11 th millennium BC. Another southern industry is the Negev Variant of the Kebaran, which on typological grounds appears to overlap both the Geometric Kebaran A and the succeeding Early Natufian. Unfortunately, there are no ${ }^{14} \mathrm{C}$ dates for the Negev Variant of the Kebaran.

The best known Epipalaeolithic industry is the Natufian, which develops out of the Geometric Kebaran A and appears widely over the southern Levant, especially in the Mediterranean hill zone. Nine of the 15 Early Natufian dates cluster within the 10th millennium BC. GL-69, -72 , and possibly -70 , which derive from the same stage and phase at Jericho as P-376 and BM-1407, are too early. These three samples were measured in 1958, and their 9th and early 8th millennia results may be due to inadequate laboratory pretreatment (Waterbolk, 1971, fig 3, legend). The three Wadi Judayid (J2) dates with midpoints falling in the 11th millennium BC, may be correct, but their uncertainties $( \pm 800, \pm$ 1000 , and \pm 659 years) are uncomfortably large.

The 5 Late Natufian dates are scattered. The oldest determination, I-5496 from Rosh Horesha, is clearly an outlier at 11,140 \pm 200 BC. The two remaining dates from this site fall in the early-mid 9th millennium, while the Nahal Oren and El-Wad $B_{1}$ dates are late 9th to early 8th millennium. Overall, the Natufian appears to date ca 10,000 to $8500 / 8000$ BC, but the end of this industry will remain uncertainly dated until more assays become available.

Two typologically late Epipalaeolithic industries are the Harifian in the Negev and northern Sinai, and the Khiamian, which has been identified at several widely scattered sites in Sinai and elsewhere in the 
southern Levant. The absolute chronology of the Harifian is largely dependent on three remarkably homogeneous ${ }^{14} \mathrm{C}$ dates from a single site in the central Negev, Abu Salem. These assays (I-5498 to -5500) suggest that there may be a slight overlapping of the Harifian and the beginning of the Early Neolithic I period in the late 9th millennium BC, a conclusion not surprising considering the occurrence at Harifian sites of both Epipalaeolithic and Early Neolithic elements (Scott, 1977). As for the Khiamian, it has a single radiometric date (Pta-2699) from Abu Madi, an unpublished site in southern Sinai. The result is similar to the Harifian and earliest Early Neolithic I dates and corresponds nicely with the transitional late Epipalaeolithic-Early Neolithic character of the Khiamian (Bar-Yosef 1981a, p 402; 1981b, p 561-562).

\section{Neolithic period}

The Neolithic period is divided into four phases. Many archaeologists follow Kenyon (1979) in referring to these stages as Pre-Pottery Neolithic (PPN) A and B and Pottery Neolithic (PN) A and B. Moore (1982) has recently proposed Neolithic 1, 2, 3, and 4 for these divisions, while the author prefers Early Neolithic I and II and Late Neolithic I and II. Calibration of ${ }^{14} \mathrm{C}$ dates first becomes possible with the Late Neolithic period.

All but 2 of the 22 EN I dates (23 if the "Proto-Neolithic" assay is included) come from Jericho. Most of these dates came out in five series: 1 from the Geochronological Laboratory, London (measured in 1956), 3 from the British Museum, and 1 from Pennsylvania. The GL series is too young, probably because of inadequate sample pretreatment, and BM-105, -110 , and -250 may be too old (Burleigh, 1984, p 760, fig 352, legend). 'The remaining Jericho dates range from ca 7800 to 7200 Bc. One of the 2 Netiv Hagdud dates (RT-502A) comes at the upper end of this range, while the second assay (RT-502B) has a late 9th millennium measurement.

Early Neolithic II is represented by no less than 56 dates, 3 of which (Lv-358, M-1792, and Pta-3486) are clearly too young, and 1 (Pta-2700) is too old. The 17 Beidha assays, which run from ca 7100 to $6600 \mathrm{BC}$, present some internal inconsistencies. For example, GrN-5062 and P-1382 from late Level II are considerably earlier than K-1085, which comes from the same charcoal sample. In fact, these two dates are contemporary with K-1086 and -1410, which were collected from the stratigraphically later Level VI. Also, the four dates obtained from the carbonized trunk of a pistacia tree in Level IV cover the entire chronologic range of the site (though one of these samples, K-1083, may have been mislabeled). The 21 Jericho dates (except for 3 of the GL entries) cover roughly a 600 -year period, from ca 7200 to 6600 вс.

Although it was long thought that the Early Neolithic period ended with a general abandonment of the settlements in the southern Levant, perhaps as the result of climatic dessication (Blake, 1969), new ${ }^{14} \mathrm{C}$ dates emanating from the southern Negev, the Arabah valley, and south Sinai suggest a somewhat different picture. Ten of the 11 dates from Mazad Mazal, Nahal Issaron, and Ujrat el-Mehed fall in the 2nd half of the 7th 
millennium BC. If these determinations accurately reflect the age of these sites, then EN II had a life-span considerably longer than that of EN I, and the EN II period at Beidha and Jericho came to a close 400 to 500 years earlier than it did in some of the small desertic sites in the south.

There was evidently a gap in occupation at major Palestinian sites between the Early and Late Neolithic periods, but the extent of this discontinuity cannot be estimated with any confidence because of a paucity of LN I dates. The calibrated values of two isolated LN I dates (Hv-8509, Pta-2999) are in the 2nd and 3rd quarters of the 6th millennium BC. There is also a Late Neolithic date from Kadesh Barnea 3 (SMU-662), which, if it could be calibrated, would fall somewhere in the late 7 th millennium BC. Such a figure seems much too early for a Late Neolithic site. Although it is not possible to correct the late EN II dates to get a true estimate of the time differential between EN II and LN I, one might hazard a guess that the break lasted for 500-700 years. Needless to say, further excavations and additional ${ }^{14} \mathrm{C}$ dates may show this "gap" to be much shorter than it now appears or to be of unequal duration in different parts of the southern Levant.

The three LN II dates from Newe Yam and Ein el-Jarba, and the single Late Neolithic/Early Chalcolithic determination from Tell Tsaf, have a wide scatter. The amount of collagen in GX-786 from Ein el-Jarba was small, so the result for this sample was understandably anomalous. The 5 Teleilat el-Ghassul samples listed under "Late Neolithic/Early Chalcolithic" come from levels considered early Chalcolithic by the excavator. However, considering the close links between the pottery and flaked stone tools found in these levels and in Late Neolithic contexts elsewhere in the Levant (Hennessy, 1982), it would not be surprising to see these dates, which cover the period from ca 5600 to $4900 \mathrm{BC}$, eventually classified as LN II assays.

\section{Chalcolithic period}

A dearth of well-stratified and fully published sites, difficulties in correlating the archaeologic assemblages between different areas in the southern Levant, an absence of closely datable foreign correlations, and the lack of a distinct stratigraphic or typologic boundary between Late Neolithic and early Chalcolithic has made Chalcolithic chronology a particularly vexing subject. Of 18 Chalcolithic ${ }^{14} \mathrm{C}$ dates, 3 (C-919, P-2572, and BM-1116) are clearly anomalous (the latter perhaps due to misassociation of the sample), and while many of the rest show no obvious deficiencies, cumulatively, they leave a disturbing gap between the end of the Chalcolithic period and beginning of the Early Bronze age.

There are 7 late Chalcolithic dates from the northern Negev. C-919 (a solid-carbon date) from Horvat Beter is much too old and the $9 \mathrm{Bir}$ es-Safadi clates (M-864A to $\mathrm{C}$ ) have uncomfortably large uncertainties, as does $\mathrm{RT}-554 \mathrm{~B}$ from a small sample found at Shiqmim. The 2 remaining dates, W-245, from Horvat Beter, and RT-554A, from Shiqmim, have no apparent technical problems, but their calibrated results, like those from 
Bir es-Safadi, leave a gap of several hundred years between the Chalcolithic and the beginning of the Early Bronze age.

Six late Chalcolithic dates also come from caves in the Judean desert. The 4 from Cave 1 at Nahal Mishmar are associated with that grotto's famous copper treasure. Except for BM-140, the assays cluster in the 2nd quarter of the 4th millennium BC, which is somewhat earlier than the date given the treasure on archaeologic grounds (Bar-Adon, 1980, p 199). I-1819, which comes from a piece of cloth found in a burial in nearby Cave 2, is slightly younger, but another short-lived sample, I-616 from the Cave of Horror at Nahal Hever, gave a result in the late 5th millennium.

RT-390A comes from a piece of wood found in a classic "Ghassulian" (ie, late Chalcolithic) level at Teleilat el-Ghassul. Since the sample was part of a larger piece of wood left in storage since the original 1928-1939 excavations at this site, too much significance should probably not be attached to the date (4445-4320 BC). SMU-804, a mid-5th millennium BC assay from the lower of two Chalcolithic layers at Jebel Queisa (J24), is reported to lie close to the mean of 21 dates from sites in Sinai associated with the Timnian industry of the late Chalcolithic period (Henry, 1982, p 443). RT-525 from late Chalcolithic Rasm Harbush in the Golan gave a slightly later date (4380-3880 вс).

Altogether, these dates are a mixed lot. They, together with the Late Neolithic/Early Chalcolithic dates, suggest that the Chalcolithic period is fairly long, beginning no later than perhaps the mid-5th millennium. However, many of the assays are simply too early for the late Chalcolithic era. That the period ends in about the 34th century BC can be deduced from the ${ }^{14} \mathrm{C}$ dates available from the following Early Bronze age IA. Little will be gained by further debate on the present assays: what is really needed are several series of dates from well-stratified Chalcolithic sites.

\section{Early Bronze age}

The Early Bronze age has four major divisions, designated Early Bronze (EB) I (with Phases A, B, and C), II (A and B), III (A and B), and IV (A, B, and $\mathrm{C}$ ). (In this paper, the designations EB IVA, B, and $\mathrm{C}$ and Middle Bronze I, II, and III follow Dever, 1973, fig 1 and p 60, n 56.) There are 96 Early Bronze age dates, the largest of any period in Palestinian archaeology. Most come from 1 of 6 sites: Ai, Arad, Tell Areini, Bab edh-Dhra, Jericho, or Numeira.

The EB IA and IB periods are roughly synchronous with the late Predynastic period in Egypt and, as such, can be dated ca 3400 to 3200 ! 3100 BC. Four of the 5 EB IA dates from Tomb A 94 at Jericho overlap and support this chronologic scheme. GL-24, which was measured in 1953, is an outlier. The mini-series SI-3310A, $-3310 \mathrm{~B}$, and -3311 from Bab edhDhra is incongruous. The first and second samples came from a transitional EB IA/B tomb and produced an acceptable date (SI-3310A) of 3545-3345 BC and a date that is ca 2000 years too early (SI-3310B). The third sample came from an EB IA tomb and gave a "modern" reading. 
The EB IC period is contemporary with the very end of the Predynastic period in Egypt and the first several reigns of Dynasty I, while EB II is contemporaneous with the remainder of Dynasty I, II, and part if not all of Dynasty III. Based on this correlation, EB IC dates ca 3200/ 3150 to $3000 \mathrm{BC}$, and EB II ca 3000 to $2750 / 2700$ BC.

The two groups of EB IC and EB II dates from Arad are problematic. The Isotopes date from Stratum I is anomalous, perhaps because of contamination by surface vegetation, while the 3 other carbonized wood samples yielded ${ }^{14} \mathrm{C}$ ages that are virtually identical, despite the fact that they derive from 3 different strata (IV, III, and II). The problems are quite different with the Pennsylvania assays. Six of the 7 Pennsylvania dates come from short-lived samples. Two samples (P-2054 and -2055) were redated because their results were too early; the new determinations (P-2054A and -2109) were considerably lower. Another curious phenomenon is that the calibrated results for the 4 acceptable Stratum II dates $(\mathrm{P}-1742,-2054 \mathrm{~A},-2109$, and -2110$)$ cover a range of 530 years (3065 to 2535 $\mathrm{BC}$ ), despite the fact that the samples belong near the end of the stratum.

Tell Areini has yielded $8{ }^{14} \mathrm{C}$ dates, including 7 from a British Museum series. Interestingly, the BP measurements for the 4 Stratum IV samples (BM-388, -389, 391, and W-916) average ca 200 years earlier than the 4 Arad Stratum II bP values. Since both groups derive from short-lived samples, and since Stratum IV at Tell Areini probably belongs early in EB II, while Stratum II apparently relates to the end of this period, the ${ }^{14} \mathrm{C}$ dates suggest a fairly long EB II period in Palestine. An extended EB II period has also been postulated by Dever (1982) on the basis of the archaeologic evidence from Arad.

The 23 EB IC, EB II, and EB III dates from Ai are a curious lot. Initially, 14 samples, both short-lived and long-lived, were sent to the Texas and Gakushuin laboratories. One of the resulting dates (GaK-2380) was acceptable; the other 13 (Tx-1026 to -1035, GaK-2379, -2381, and -2382) were too early by anywhere from 300 to 700 years. Subsequently, 9 more samples, all but 2 utilizing additional quantities of the same sample material taken out of the original collection containers, were run at Pennsylvania and Texas. This time the dates (P-2298 to -2304, Tx-2371 to -2372) agreed consistently with what was generally expected on archaeologic and historic grounds (Callaway \& Weinstein, 1977, p 5-10). Since the same erroneous results would have shown up in the second batch of dates if the sample material used for both dating runs had originally been exposed to on-site contamination or sampling error, an explanation for the initial group of deviant dates is presumably to be sought in the handling or processing of the samples.

The longest phase of the Early Bronze age is the EB III period, which, on the basis of Egyptian and Syrian connections, can be dated from ca $2750 / 2700$ to perhaps the late 24th century BC. Most of the assays relating to this period come from Bab edh-Dhra, Jericho, and Numeira.

The 2 Jericho series (BM-548 to -554 , BM-1778 to $-1781,-1783$ ) corroborate the archaeologic evidence that EB III is the longest period of the 
Early Bronze age. The first series ranges from 2925 to 2305 вс, while the second series extends from 2920 to 2310 вс. The one notable inconsistency is between BM-552 (2885-2635 BC) and BM-1780 (2430-2305 BC), which come from the same stage and phase, but this discrepancy may simply reflect the dating of wood of different ages.

The Bab edh-Dhra and Numeira dates present some interesting problems. For example, the entire series, SI-4134 to -4138, is anomalous. SI-4134 and -4135 from Bab edh-Dhra are more than 1000 years off. SI-4136 and -4138, which come from late EB III destruction debris at Numeira (Rast, $1981, \mathrm{p} 37,41)$, are several hundred years too early to pertain to the end of EB III, though they could certainly reflect the dating of early growth rings of older wood. As for SI-4137, the date, which is 500 to 600 years too old, comes from grapes which were collected in a water flotation device. Whether contaminants in the water could have affected the result so significantly must be left to others more qualified than the author to judge.

Six ${ }^{14} \mathrm{C}$ dates (M-2036 to -2037, SI-2497, -2499, -2501, and -2874) come from short-lived and long-lived samples deriving from several of the large charnel houses at Bab edh-Dhra. These assays cover a wide range, but there is nothing intrinsically wrong with them. Charnel houses A 8 and A 51 were first used in EB II and continued on through EB III (R T Schaub, pers commun), while A 55 began in EB II and was not finally abandoned until early EB IV (Rast \& Schaub, 1978, p 24). Since the point in time when each of the samples got into the charnel houses cannot be determined, the chronologic range of all of the material in each tomb must be considered. Thus, 2 of the A 55 dates, SI-2501, at 3365-2925 вс, and SI-2497, at 2305-1905 BC, are equally likely to be correct. This situation illustrates an important problem in Near Eastern ${ }^{14} \mathrm{C}$ dating. Many contexts (especially constructional fills, pits, and multiple-burial tombs) contain jumbled materials of several different periods. In such situations it is difficult if not impossible to relate any organic substances not found in a datable container within the context to a specific archaeologic period. As a result, ${ }^{14} \mathrm{C}$ dates from these contexts often have little or no chronologic value, even though such sources normally yield much of the organic material (especially of the short-lived variety) found on Near Eastern sites.

The EB IV period lasts from ca $2350 / 2300$ to $2000 / 1900$ BC. Olive pits from an EB IVA context at Bab edh-Dhra yielded an excellent date (P-2573: 2335-2135 BC), while SI-2869 from the same period at this site is ca 1600 years too early. The pit in which the latter sample was found was partially cut out of the marl-limestone bedrock, but whether water running into the pit or some other contaminant may have influenced the date is a moot question. As for the EB IVB-C assays, the 2 from unpublished sites in the northern Sinai (RT-447B and -447A) have uncertainties that are too large to give the dates real chronologic value, while the 2 assays from EB IVC contexts at Jericho are in good accord with an archaeologic dating of this period to about the 21 st or 20 th century вс.

\section{Middle and Late Bronze age}

There are relatively few Middle Bronze age (ca 2000/1900 to 1550 
BC) and Late Bronze age (ca 1550 to $1200 \mathrm{BC}$ ) ${ }^{14} \mathrm{C}$ dates. As explained above, after ca $2000 \mathrm{BC}$, historic and archaeologic data generally provide more precise dating evidence for most cultural remains and stratigraphic phases then can be obtained through ${ }^{14} \mathrm{C}$ dating.

The Middle Bronze (MB) I period (ca 1900 to $1750 \mathrm{BC}$ ) has no ${ }^{14} \mathrm{C}$ dates. Seven of the $8 \mathrm{MB}$ II ${ }^{14} \mathrm{C}$ dates (ca 1750 to $1650 \mathrm{BC}$ ) come from tombs at Jericho. The samples were dated in the 1950's, and except for GL-6, the assays are quite satisfactory considering when they were produced. The eighth date, P-842 from Gibeon, is too young.

Late MB III (ca 1550 BC) contexts at Jericho, Lachish, and Shechem have each provided a single ${ }^{14} \mathrm{C}$ date. The Jericho assay (BM-1790) is too recent. The Lachish (Hel-809) and Shechem (GX-1718) samples derive from destruction debris associated with the end of the Middle Bronze age. The dates, though acceptable from a ${ }^{14} \mathrm{C}$ standpoint if the samples are from re-used wood or from the inner rings of older trees, are too early, at 1945-1675 BC and 2000-1700 BC, respectively, to have much archaeologic value. Unfortunately, although destruction debris in Palestinian Bronze and Iron age strata yields more wood and charcoal samples than any other contexts, the ${ }^{14} \mathrm{C}$ measurements from these types of samples rarely produce results of any significance for dating the destruction.

Only $6{ }^{14} \mathrm{C}$ dates can be assigned to the Late Bronze (LB) age alone: 2 from burial cave B3 at Jebel al-Qesir and 1 from the nearby settlement at Khirbet Umm ad-Dananir in Jordan's Baq'ah valley, 2 from Lachish, and 1 from Deir cAlla. The first 2 dates (P-3209 and -3210) are too early for the LB II (ca 1400 to $1200 \mathrm{BC}$ ) tomb in which they were discovered, but not nearly as early as the date of 2120-1865 BC (P-3219) from the settlement. The Lachish dates evidently come from cedar-wood architectural elements in a LB IIB (13th century) sanctuary, and though 1 of the 2 assays is more than 400 years too early, this is not unexpected in view of the nature of the sample. Cedrus libani, which was used extensively in the Levant during the Bronze age and Iron age for its excellent building properties, is extremely long-lived, with a potential life span of perhaps a millennium or more (Bryant Bannister, pers commun). Many supposedly anomalous dates derived from charcoal and wood of unidentified species are probably the result of the sample material being cedar or other long-lived wood. Unfortunately, few wood samples submitted for ${ }^{14} \mathrm{C}$ dating have been analyzed botanically. Moreover, the author has been able to find only one instance (BM-1222 from the Monastery of St Catherine) where the specific location in a section of a beam or trunk sampled for ${ }^{14} \mathrm{C}$ dating has been noted.

\section{Iron age}

Numerouts dates derive from the copper-mining installations at Timna on the western side of the southern Arabah. Nineteen are associated with Egyptian mining activity at Sites 2, 30, and 212 in the 13 th and first half of the 12th centuries BC, $i e$, LB IIB and Iron age IA. BM1368 from Site F2, entered in the corpus under "Chalcolithic Period (?)," also appears to belong to this time. The Hamburg series shows a peculiar 
phenomenon. HAM-207 to -212 (except HAM-211) are consistent with archaeologic expectations, while HAM-213 to -215 are ca $1000-1200$ years too early, and HAM-216 is perhaps several hundred years too old. Possibly some of the Site 212 samples were mislabeled, and they actually come from one of the EB II shaft-and-gallery systems at this site; if not, then a processing error must be considered as a possible explanation for these extraordinarily early dates. Incidentally, $3{ }^{14} \mathrm{C}$ dates $(\mathrm{W}-4051,-4054$, and -4456) come from slag heaps found on the eastern side of the Arabah. These have had to be listed under "Archaeological Period Unknown" because the slag cannot be dated independently.

The Iron age proper (ca 1200 to $586 \mathrm{BC}$ ) consists of the Iron IA (ca 1200 to $1150 \mathrm{BC}$ ), IB (ca 1150 to $1000 \mathrm{BC}$ ), Iron IIA (ca 1000 to $900 \mathrm{BC}$ ), IIB (900 to $800 \mathrm{BC})$, and IIC ( 800 to $586 \mathrm{BC}$ ) periods. In terms of Biblical history, Iron age $I$ is the time of the purported Israelite conquest, the Philistines, and the Judges, while Iron IIA witnesses the United Monarchy of David and Solomon, and Iron IIB-C is the time of the Divided Monarchy, which terminates with the Babylonian destruction of Jerusalem in 586 вс.

The Iron age has yielded more than 3 dozen ${ }^{14} \mathrm{C}$ dates, mostly from wood and charcoal samples, but few are of archaeologic or historic interest since they come from contexts already more closely dated than ${ }^{14} \mathrm{C}$ analysis can achieve. For example, no less than 12 assays are associated with Stratum 5 at Tell es-Sacidiyeh. According to the ceramic evidence, this stratum belongs in the 8 th century BC, but while 9 of the 12 assays overlap this century, the remaining 3 are younger. Similarly, only 1 of the 3 Lachish dates is consonant with the archaeologic evidence, and even this determination (Hel-1027) has too wide a range to be chronologically useful. The other 2 dates, which include 1 (Hel-1026) from the mid- to late 8th century BC level destroyed by the Assyrians in 701 BC, are too early for their contexts, but this is not unexpected, since both samples were wood (Hel-1025 being identified specifically as cedar).

The Tell er-Rumeith dates include several anomalous determinations, all on the young side. On ceramic grounds (Lapp, 1963; 1968) Stratum VIII at this site may be dated to the Solomonic age, so M-2031 is at least a century too young. The succeeding Stratum VII was destroyed at the beginning of the 9 th century, so M-2029 and -2030 are too recent. The two Stratum VI assays are acceptable for a late 9 th century archaeologic date, but M-2035 is much too young at 400 BC-AD 15 for Stratum V, the destruction of which has been related to the Assyrian invasion of 733 BC under Tiglath-pileser III.

Grain found inside a bronze bottle at Tell Siran in Amman furnished a ${ }^{14} \mathrm{C}$ date (P-2207: 440-395 $\mathrm{BC}$ ) that is more recent than the date of 600 BC attributed to the Ammonite inscription on the bottle itself. Since the vessel was found in a context that also contained post-Iron age remains, the grain was possibly put in the bottle later on during the Persian period. An alternative explanation is that moisture and corrosion products inside the bottle contaminated the sample material (Thompson, 1983; cf Helback, 1974). 


\section{Persian period to the Modern era}

Less than 50 dates relate to the long time span from $586 \mathrm{BC}$ to the present day, and few of these have chronologic value either for archaeologists or ${ }^{14} \mathrm{C}$ specialists. For example, the Late Hellenistic/Early Roman and Roman period dates were produced mostly during the 1950's and early 1960's. The samples originated from important excavations on the west side of the Dead Sea, such as the settlement at Qumran, Qumran Cave I, the Cave of Horror at Nahal Hever, and the caves in the Wadi Murabba ${ }^{c}$ at. These assays vary widely in their accuracy and reliability, and are generally considered curiosities today rather than sources of useful chronologic information.

Ten dates are associated with buildings of the Persian (525-332 BC) and Hellenistic (332-37 BC) periods on the acropolis at Tell es-Sa ${ }^{c}$ idiyeh. Four of the dates are from grain and charcoal samples found beneath the floor of a large Persian period administrative building. P-1445 is an outlier; the other 3 dates are acceptable. A single date from within the building itself (P-1446: 405-180 BC) has too wide a range to be of much use. A Hellenistic building, probably of the 2nd century BC, yielded 5 dates, of which 4 derive from wood beams. It may be entirely fortuitous that the lower limits for 3 of the 5 dates are 180, 170, and 165 BC. The early result for P-1098 (410-370 BC) probably signifies nothing more than the dating of inner rings from an older tree.

A unique find made in 1980 off the coast of northern Israel is the bronze battering ram from a ship. The archaeologic date of this piece of naval architecture is uncertain and could in theory be almost anywhere within the period of the 4 th to 1 st centuries BC. Wood evidently taken from the covering of the ram gave a corrected reading of 625-370 BC, which may lend support to an earlier archaeologic date.

Two samples (Hv-2675, Hv-?) of unspecified material from hearths found at the top of the Natufian Stratum $B$ at Hayonim cave yielded considerably later dates (AD 610-780, AD 35-230). These determinations show that the hearths are not connected with Stratum B, but should be connected with Late Roman-Early Byzantine Stratum A, above (BelferCohen \& Bar-Yosef, 1981, p 19-20).

St Catherine's Monastery in south Sinai was founded ca AD 530 by the Byzantine ruler, Justinian I. Within the monastery is the Church of the Transfiguration, from which 13 dates, derived from various architectural elements, have been published. The majority belong with the original construction of the church; the few that do not are evidently either aberrant (M-1677, as shown by the result for BM-1222) or possibly the result of restoration work carried out in the Church in more recent times (M-1812 and -1814).

Finally, there are 2 dates from organic inclusions in the mortar of city walls. The first (RT-?) relates to a known-age structure, the impressive Crusader wall at Caesarea, which has been dated on architectural grounds to the 13th century, possibly the 4-year period immediately following the Seventh Crusade (AD 1248-1250), when Louis IX of France was actively engaged in fortifying the Christian cities of Syria-Palestine. The assay, 
AD 890-1235, indicates the usefulness of ${ }^{14} \mathrm{C}$ for dating walls bonded with mortar, but is not sufficiently accurate to place the Caesarea wall more precisely within the Crusader period. The foundations of the city wall at Ashkelon have been attributed to Late Roman or Byzantine times, the upper section to the Crusader period. A sample taken from 50 to $120 \mathrm{~cm}$ above ground level yielded a date of AD 245-465 (GrN-7987). This suggests that at least part of the upper section of the wall may be earlier than previously supposed.

\section{CONCLUSION}

It seems appropriate to conclude this paper with a list of the principal problems and needs of ${ }^{14} \mathrm{C}$ dating as it applies to the southern Levant. The items noted below are those that the author, as an archaeologist, feels are most critical at this point. It is not unlikely that ${ }^{14} \mathrm{C}$ specialists will wish to delete some entries and substitute others.

1. More care is needed regarding the identification of natural contaminants on archaeologic sites and their effects on ${ }^{14} \mathrm{C}$ samples. This is especially necessary if samples collected from Palaeolithic caves are ever to yield useful chronologic results.

2. Additional series of dates are needed for most of the earliest periods, notably the Middle and Upper Palaeolithic, Epipalaeolithic (especially the Kebaran industry), Late Neolithic, and Chalcolithic. Accelerator dating systems would be especially appropriate for the Palaeolithic samples. 3. Archaeologists should publish more information in Radiocarbon on the stratigraphic position and archaeologic relationships of ${ }^{14} \mathrm{C}$ samples. Close to 150 dates from the southern Levant have appeared only in Radiocarbon, and the absence of detailed archaeologic data for many of these samples seriously limits their use for chronologic purposes.

4. More concern must be given for eliminating the systematic misdating of entire series of samples. Whether these errors arise through on-site contamination, mishandling and improper storage, or laboratory equipment failure, the fact is that large numbers of dates (from the Amud, Kebara, and Tabun caves, $\mathrm{Ai}, \mathrm{Bab}$ edh-Dhra and Numeira, Timna, and Tell er-Rumeith) have genuine problems. Difficulties with the Palaeolithic assays may well be attributable to special conditions existing within the caves, and archaeologic misattribution or mislabeling may be responsible for problems with a few other dates, but such explanations will not suffice for the majority of the anomalous dates.

5. Botanical analysis of all wood and charcoal samples is essential, as is identification by the archaeologist of the precise location of the sample in the section of a beam or tree trunk.

6. ${ }^{14} \mathrm{C}$ samples should not be collected from Middle Bronze age or later contexts unless the archaeologic dating evidence is inadequate (eg, in the case of a furnace or slag heap unaccompanied by any pottery or inscriptions).

7. Archaeologists should limit their collection of samples to deposits possessing chronologically homogeneous remains; by-and-large, organic ma- 
terials from pits, levelling and glacis fills, multi-period tombs, and even many destruction deposits should be ignored.

Radiocarbon dating has made major contributions to the archaeology of the southern Levant in dating isolated contexts, strata, whole sites, and even entire periods. With more help from scientists in the areas of natural and artificial contaminants and laboratory processing problems, and with more care on the part of archaeologists in collecting and submitting better samples and interpreting the resulting dates, this technique will become an even more valuable chronometric tool in the archaeology of the southern Levant.

\section{ACKNOWLEDGMENTS}

The author is indebted to many people for the writing of this paper. John Basil Hennessy, University of Sydney, Walter E Rast, Valpariso University, and R Thomas Schaub, Indiana University of Pennsylvania generously contributed unpublished ${ }^{14} \mathrm{C}$ dates. Patrick McGovern, MASCA, University Museum, University of Pennsylvania, supplied advance information on the ${ }^{14} \mathrm{C}$ dates from the Baqcah valley, Jordan, which have now been published in Radiocarbon, v 26, no. 2. Bryant Bannister, Laboratory for Tree-Ring Research, University of Arizona, Amnon Ben-Tor, Institute of Archaeology, The Hebrew University of Jerusalem, Barbara Lawn, Department of Physics, University of Pennsylvania, Andrew Moore, Department of Anthropology, Yale University, James A Sauer, University Museum, University of Pennsylvania, and Joe D Seger, Cobb Institute of Archaeology, Mississippi State University kindly answered my questions on various archaeologic and laboratory matters. Richard Burleigh, Research Laboratory, The British Museum, has to be thanked for furnishing a preprint of his paper on the Jericho ${ }^{14} \mathrm{C}$ dates that has just appeared in the final volume of the Jericho publication series. Special thanks are due Jeffrey Klein of the Department of Physics, University of Pennsylvania for giving the author an advance copy of the CRD-1 $\sigma$ calibration table. Finally, Renee Kra, Managing Editor of this journal, must be thanked for allowing the author to check the various laboratory date lists scheduled to appear in Radiocarbon, v 26, and for her assistance and patience in the production of this article. 


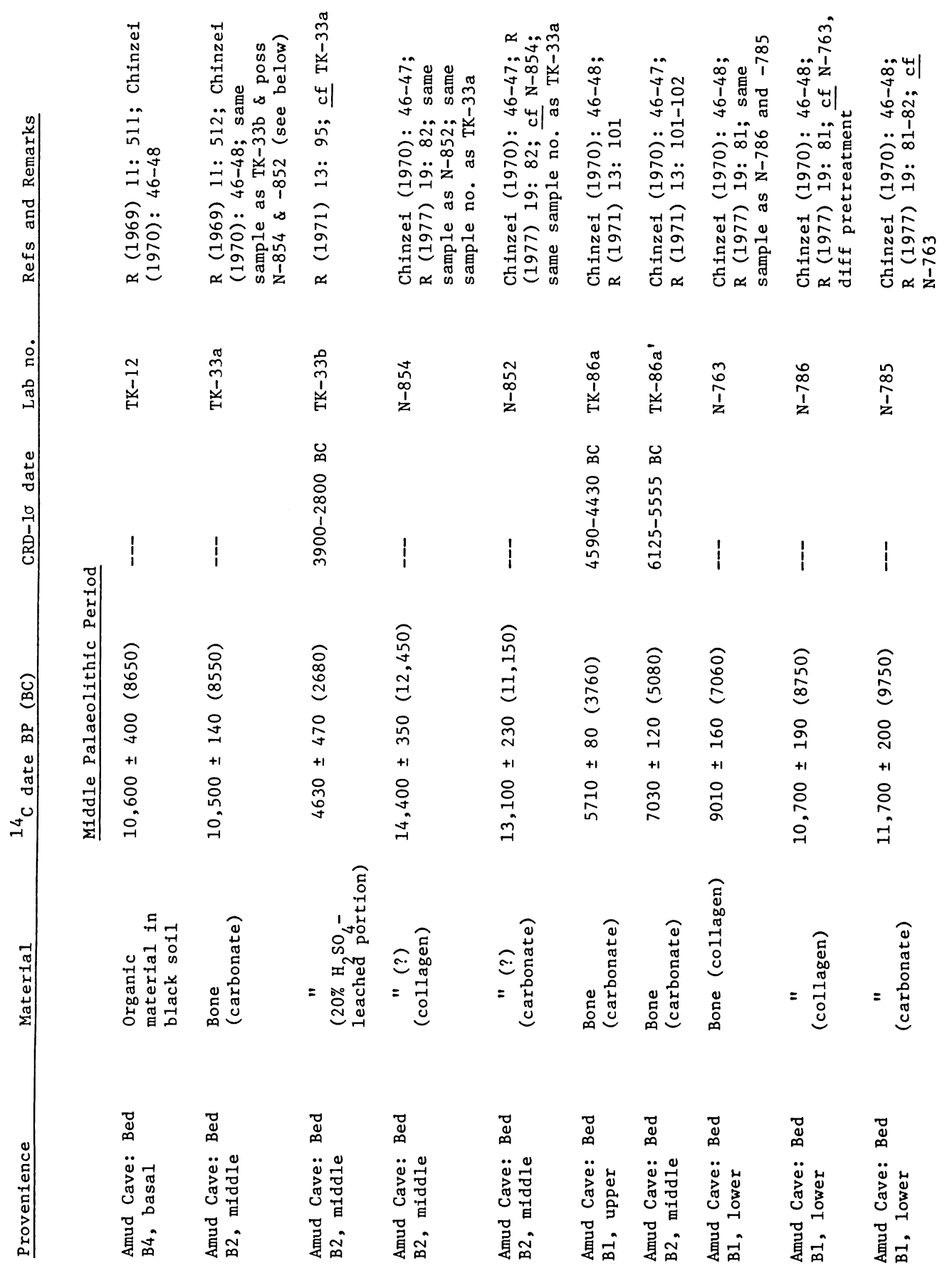




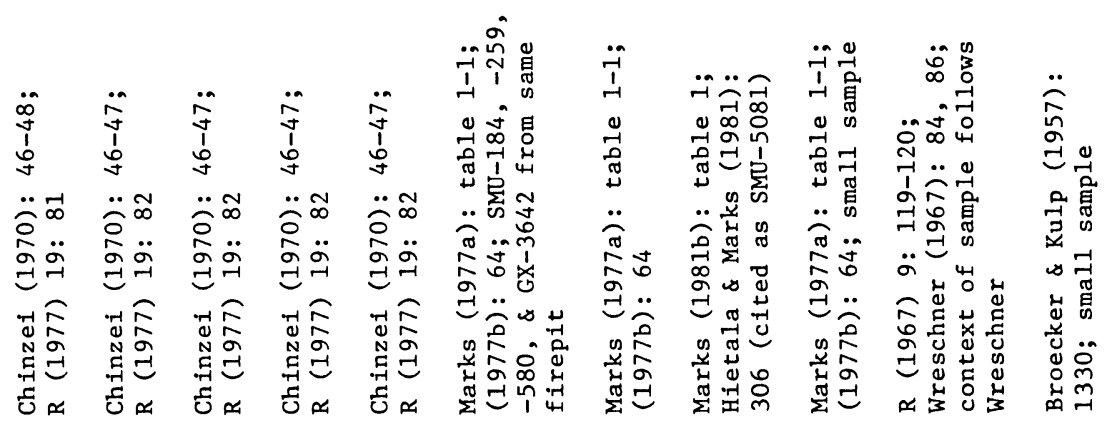

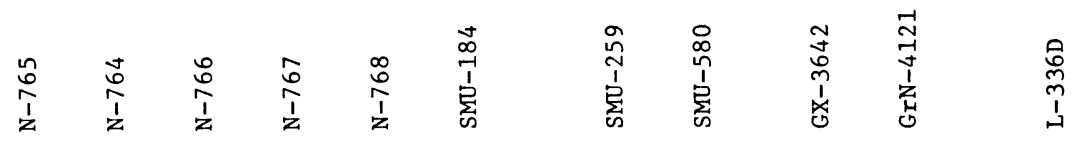
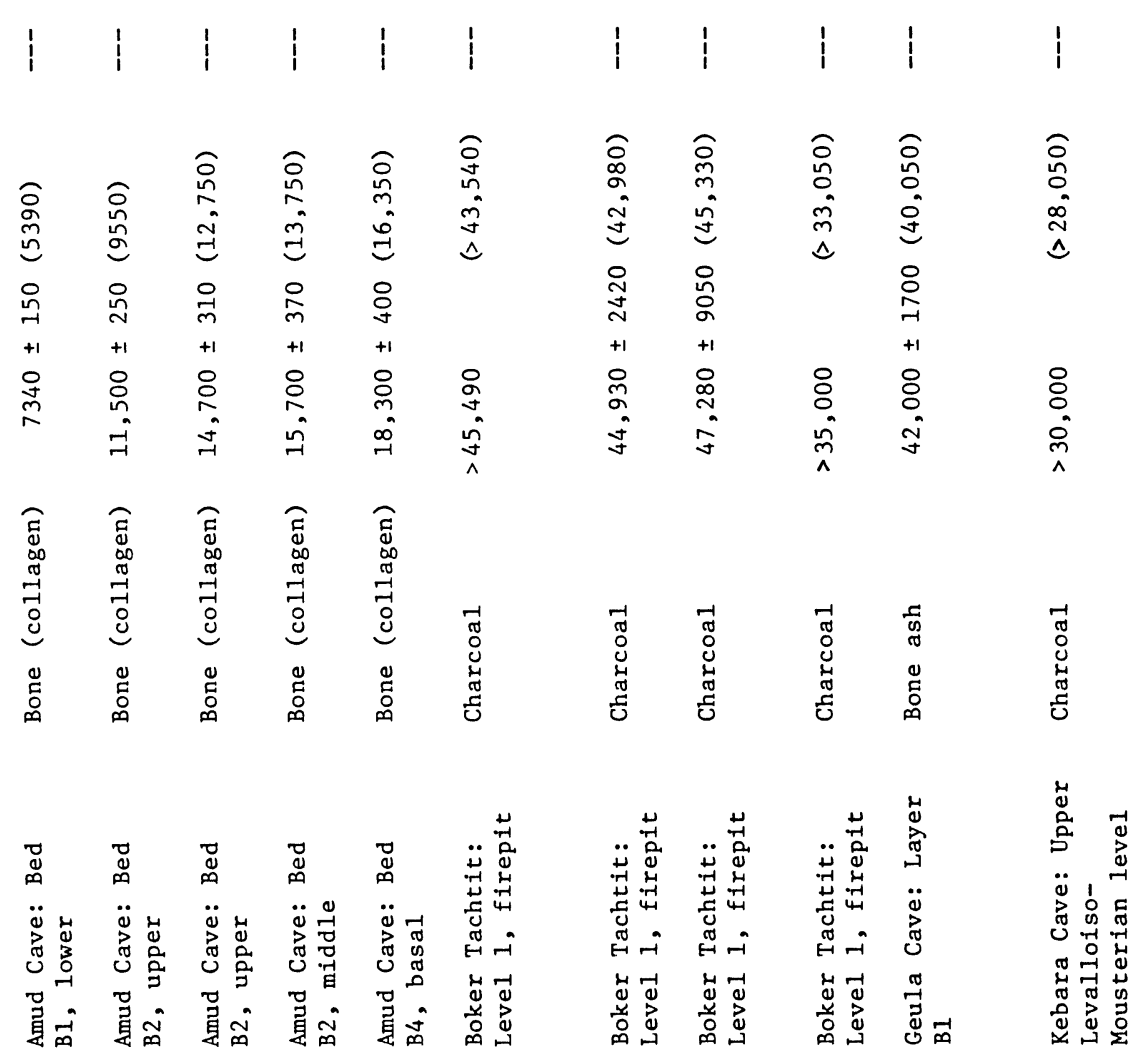


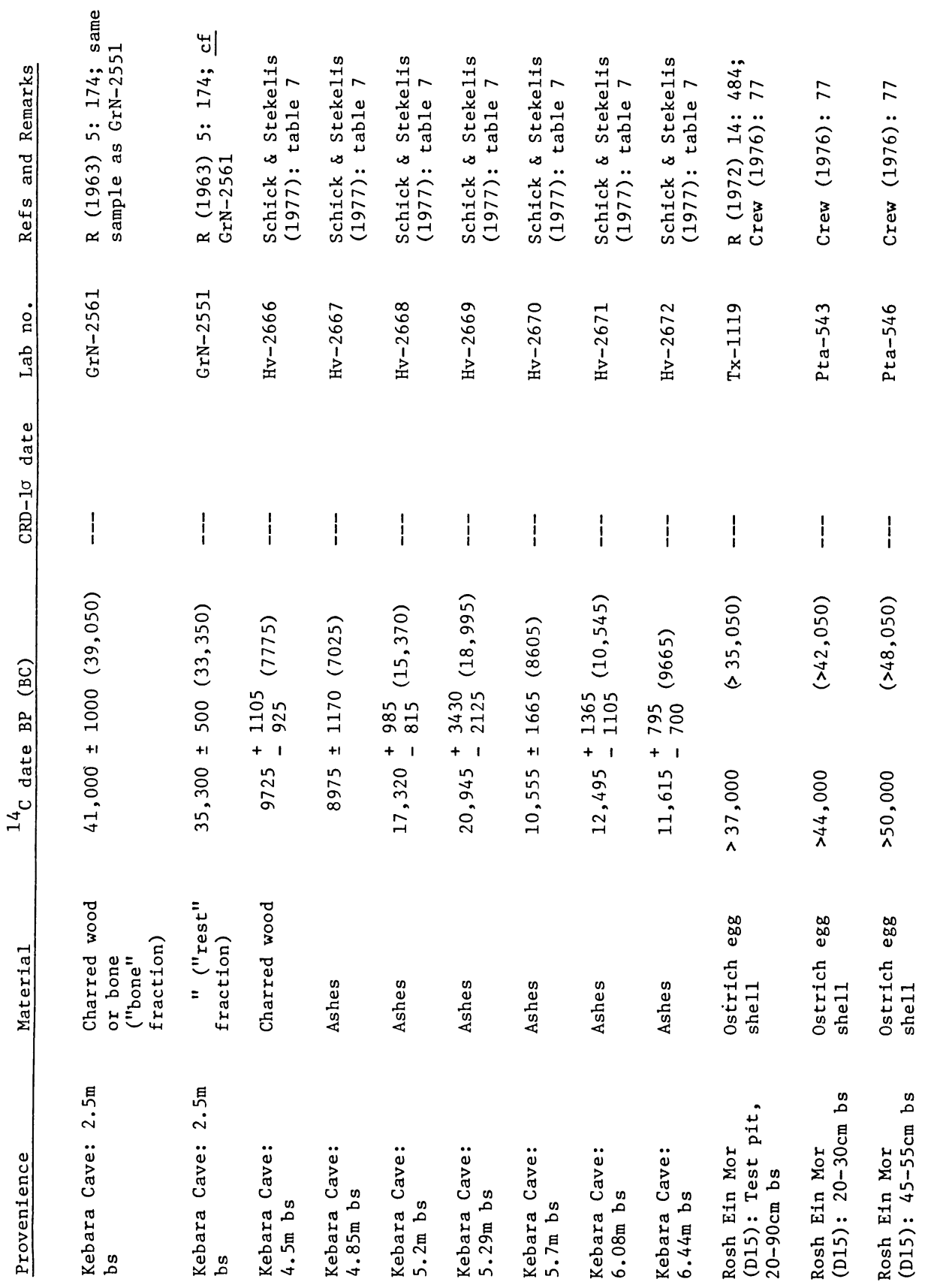




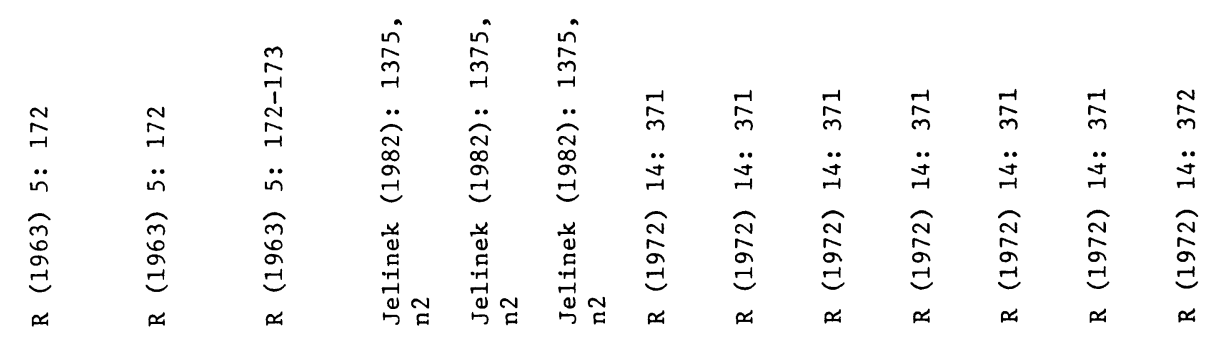

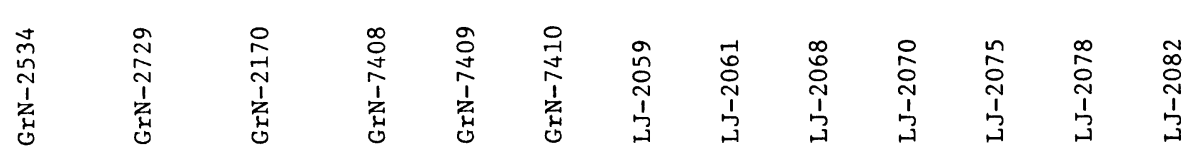

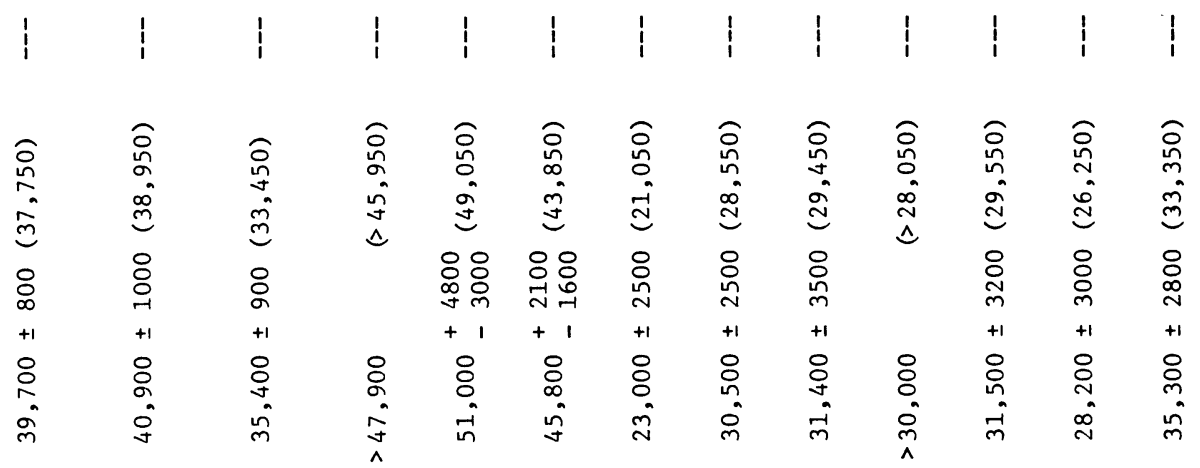

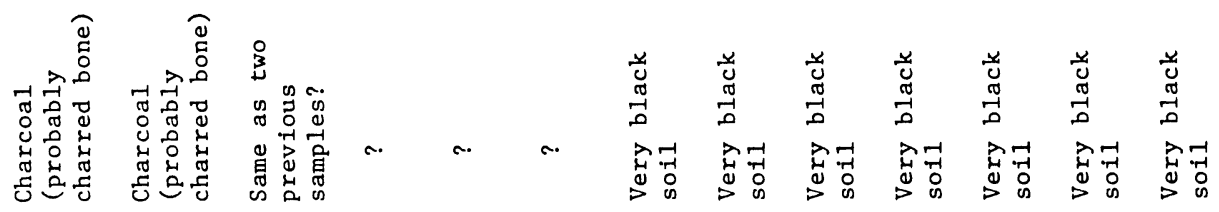

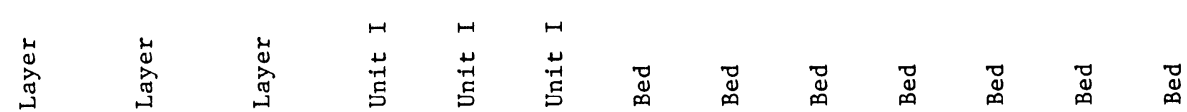

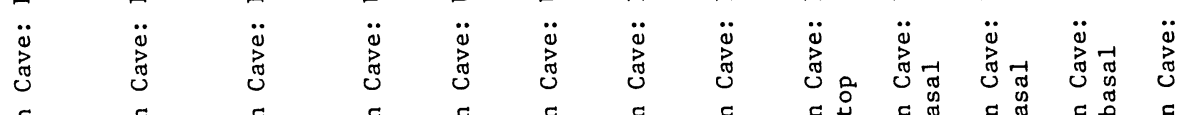

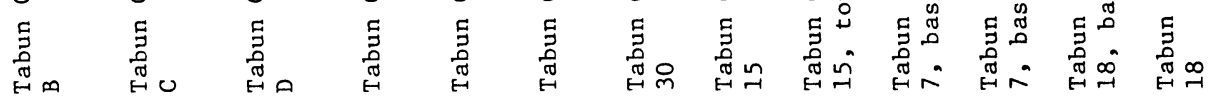




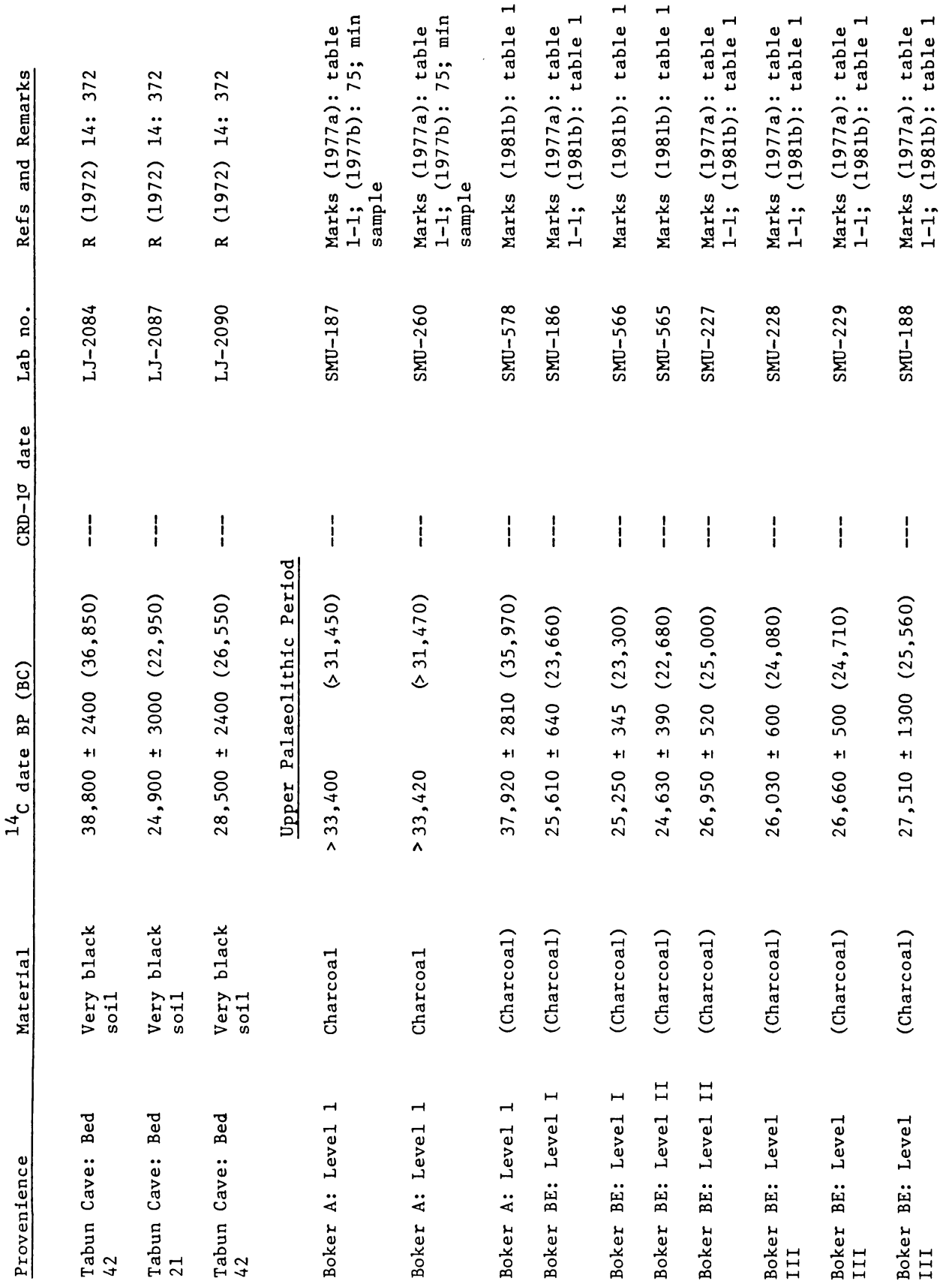




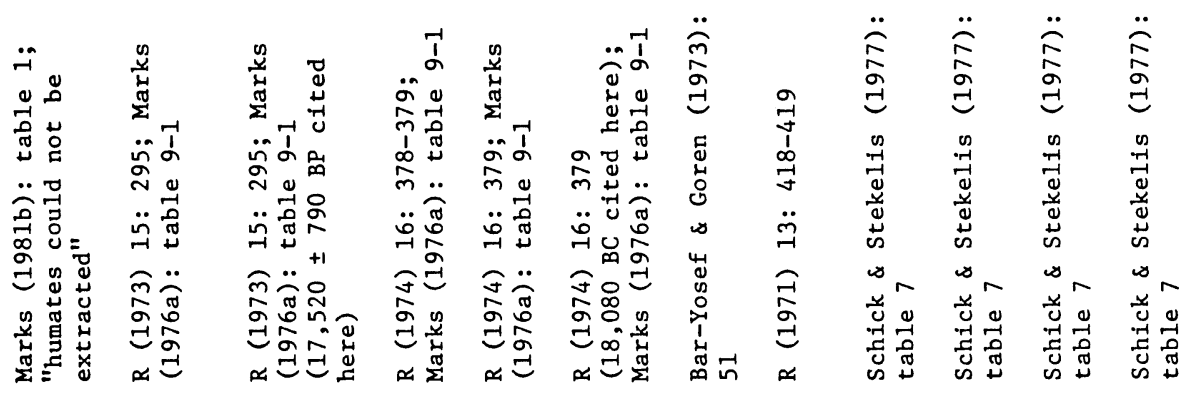

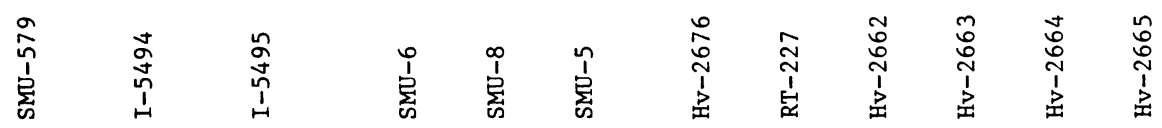

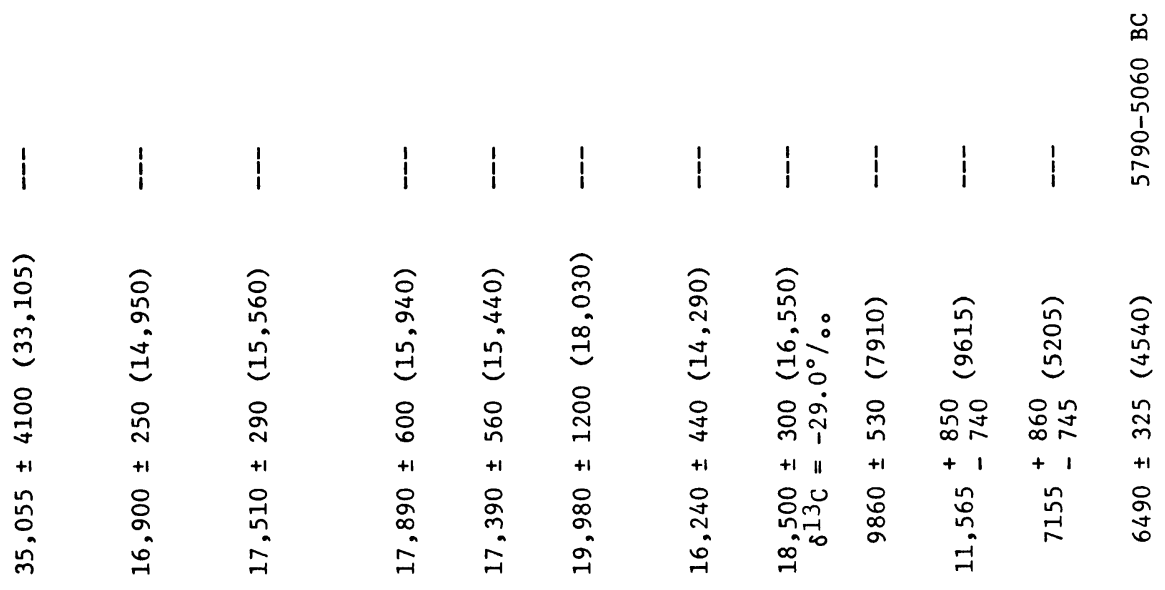

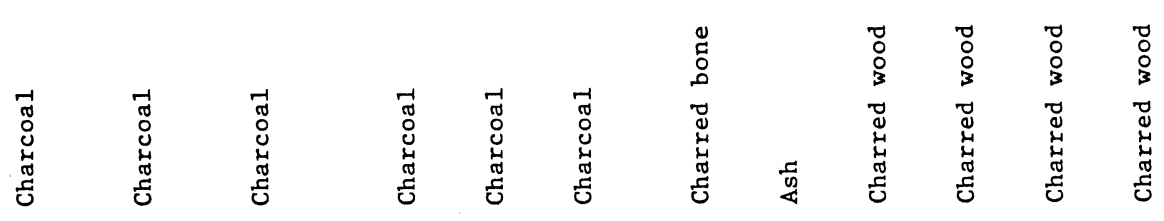

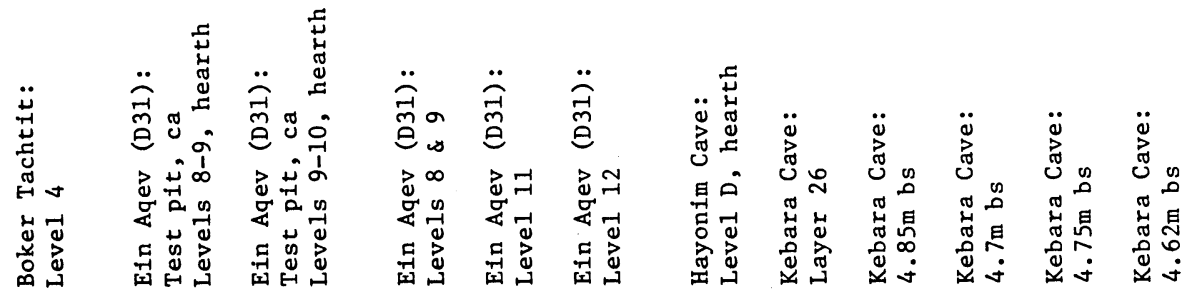




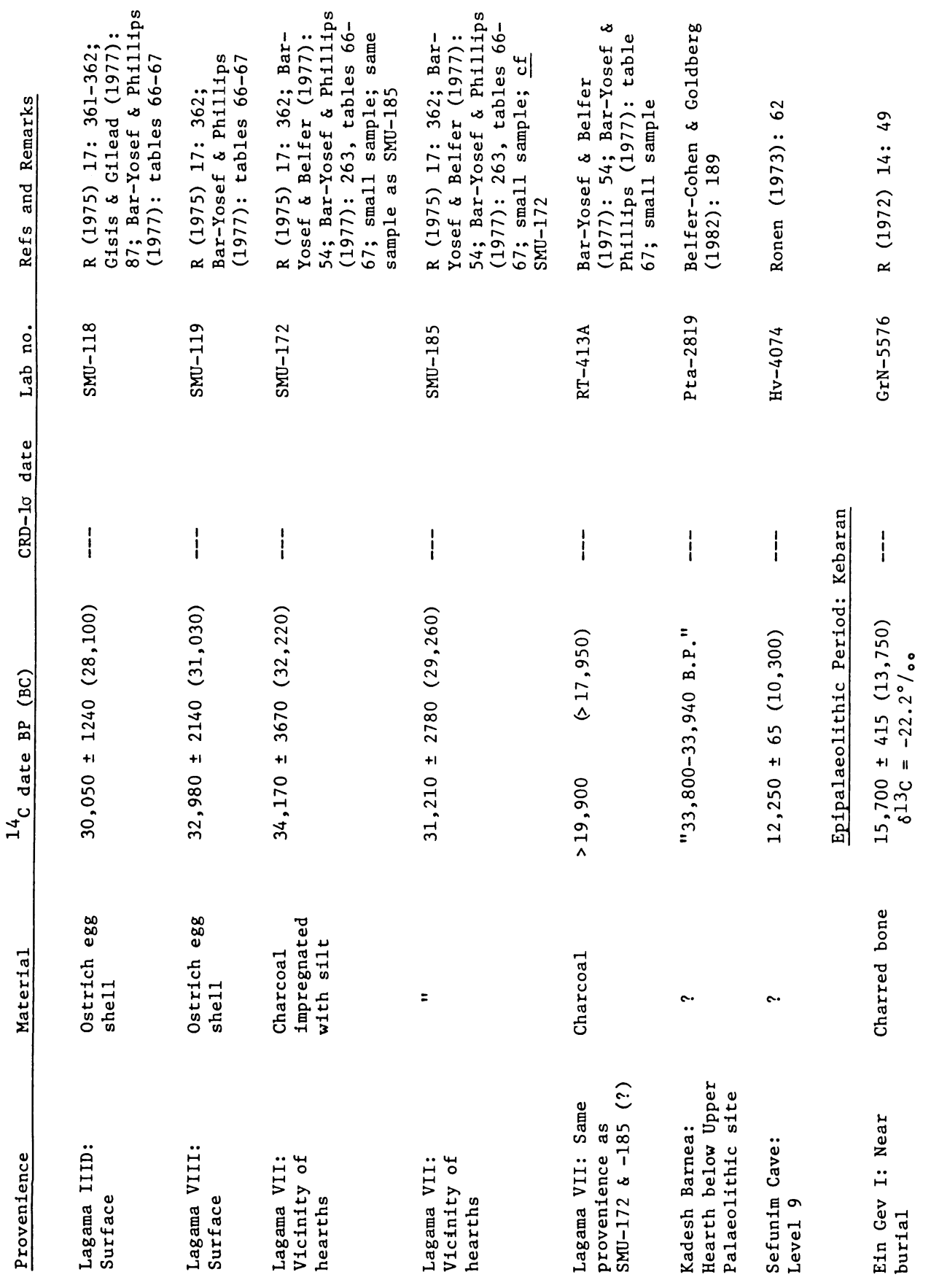




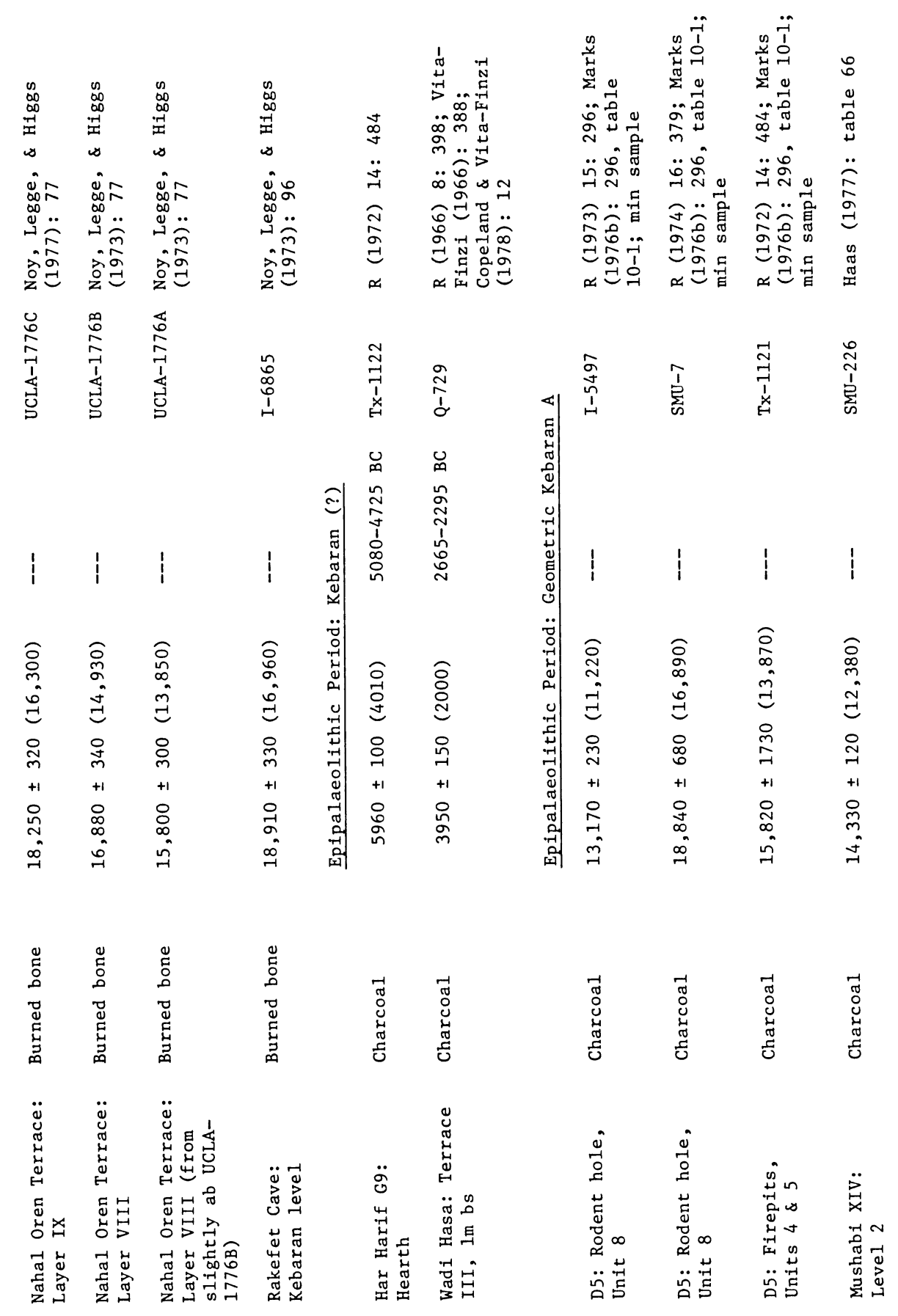




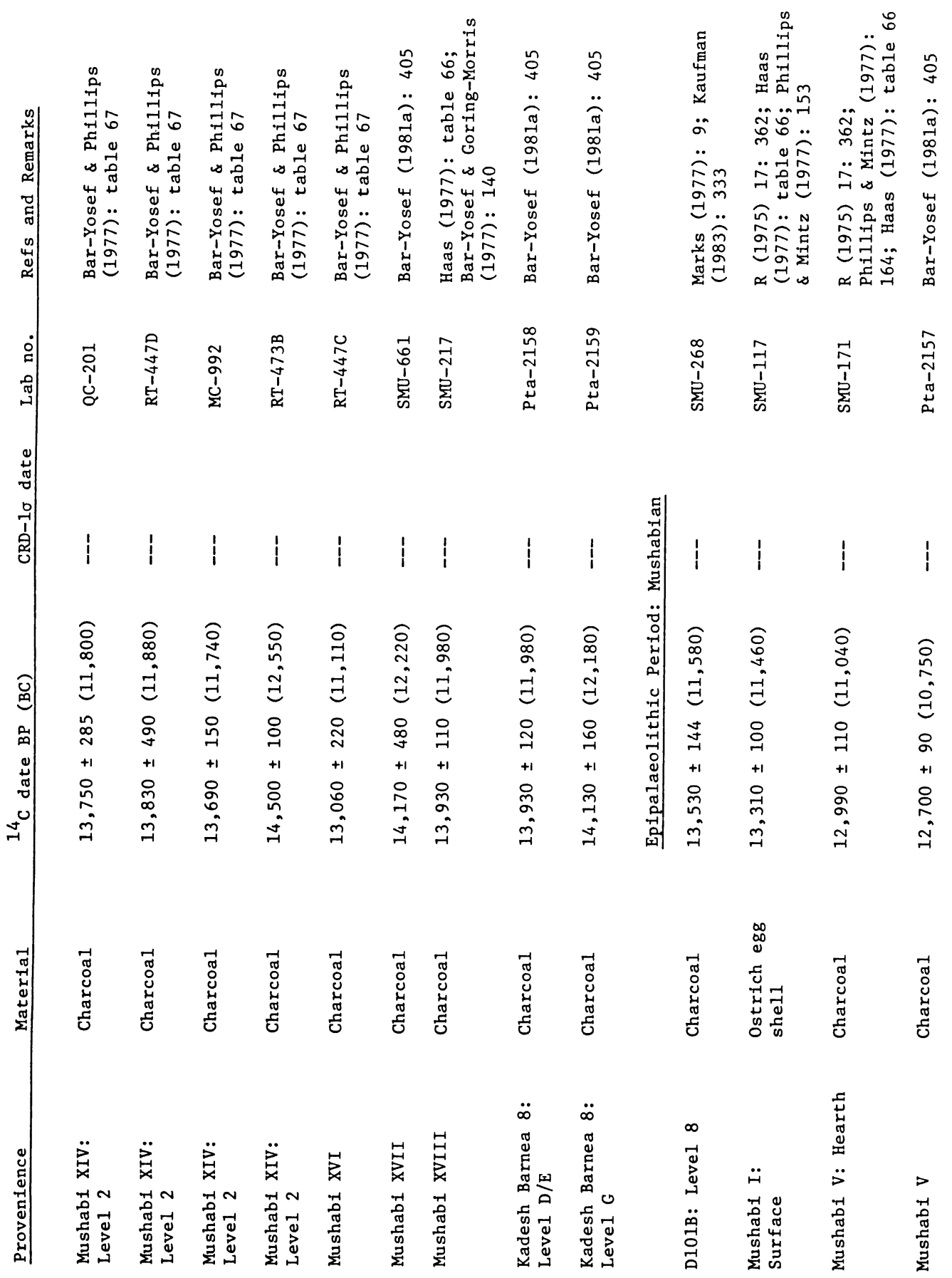




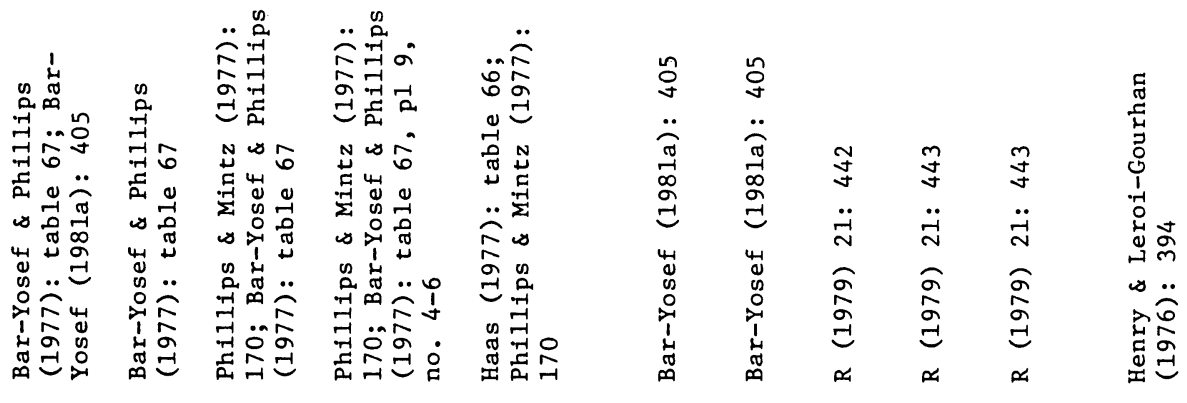

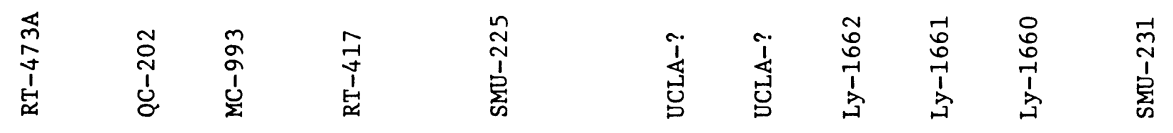

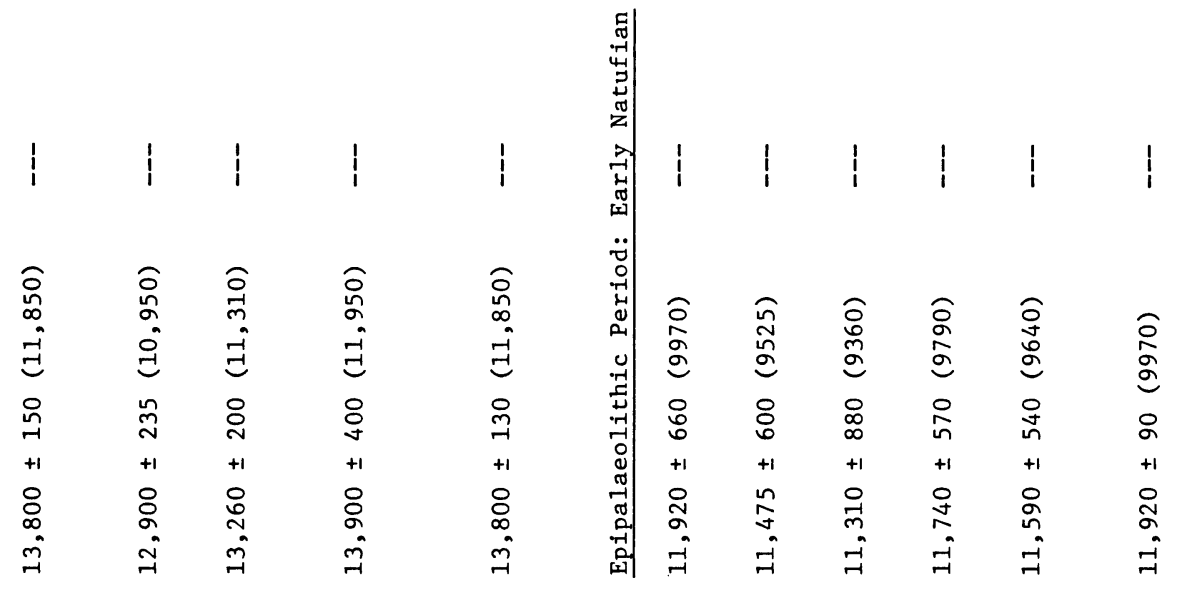

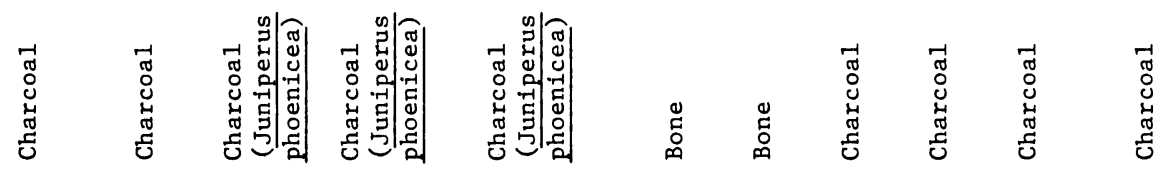

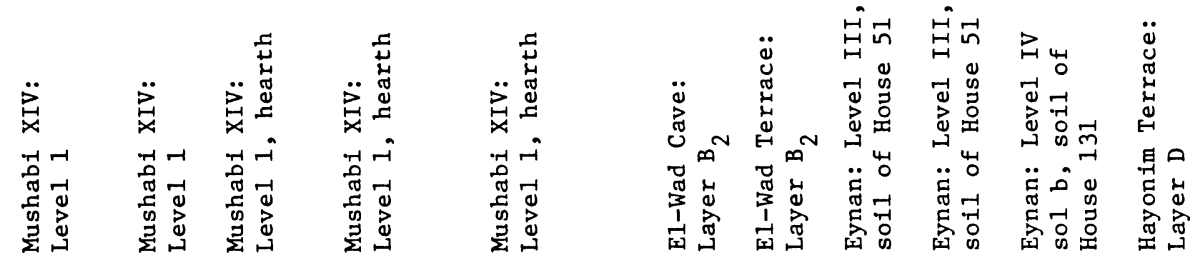




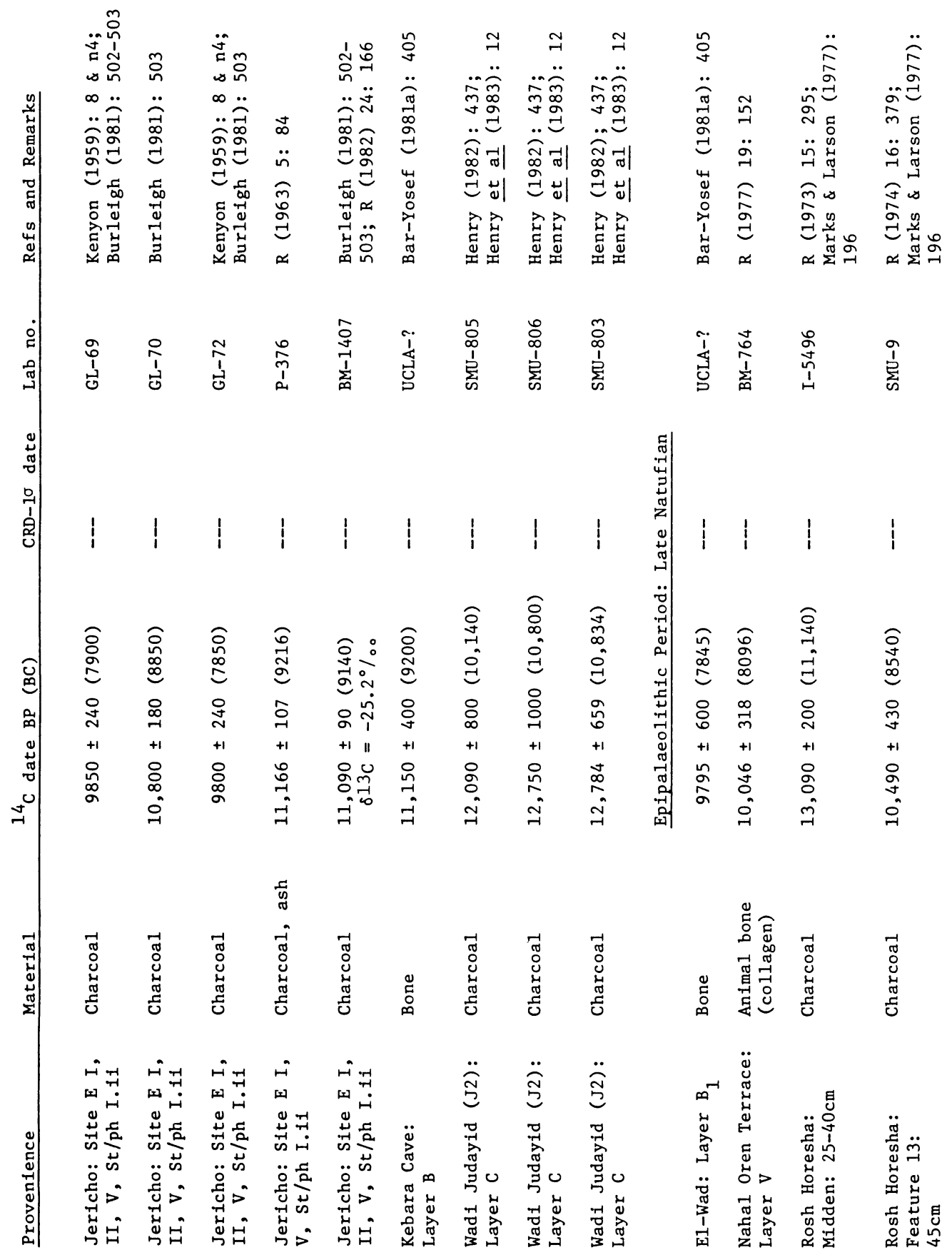



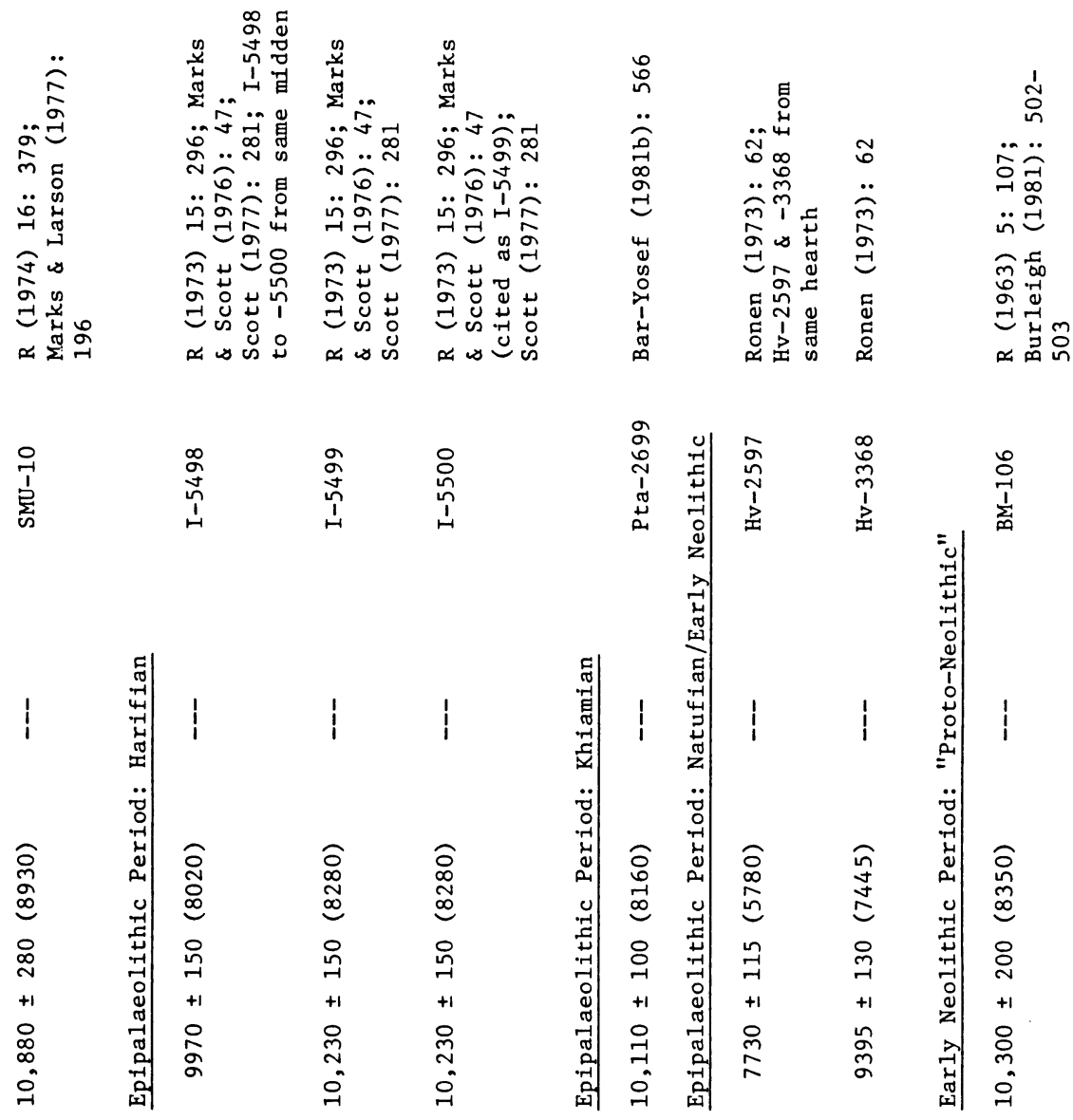

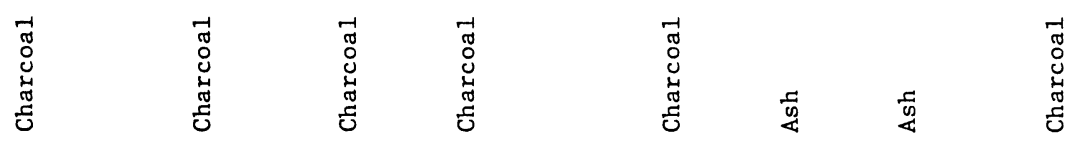

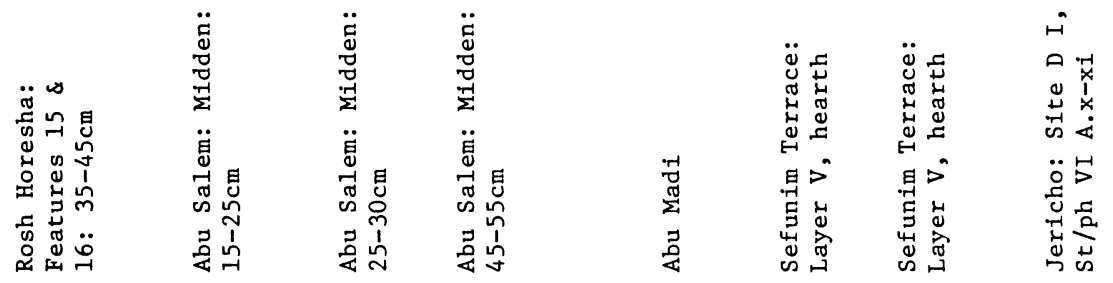




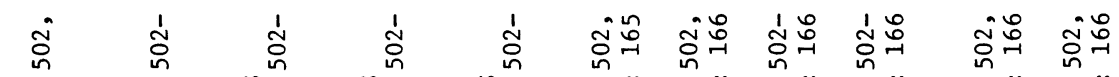

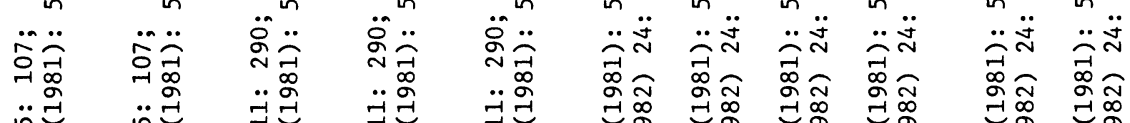

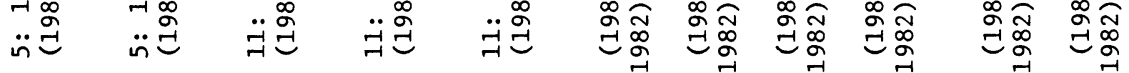

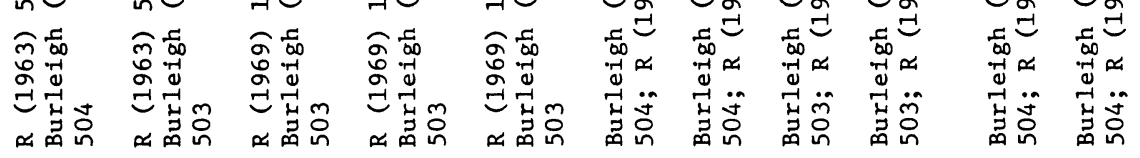

I $\begin{array}{lllllllllll} & & & & & \\ 0\end{array}$

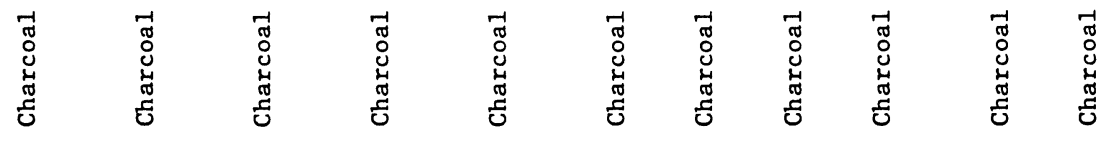

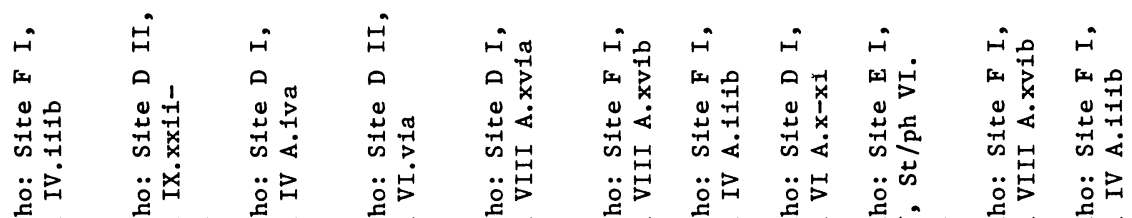

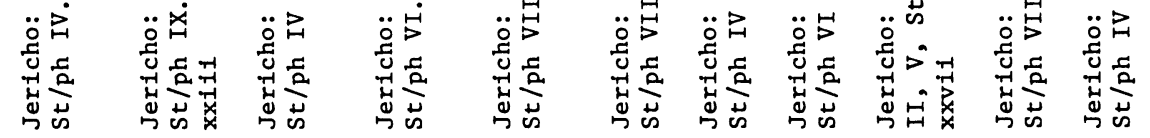




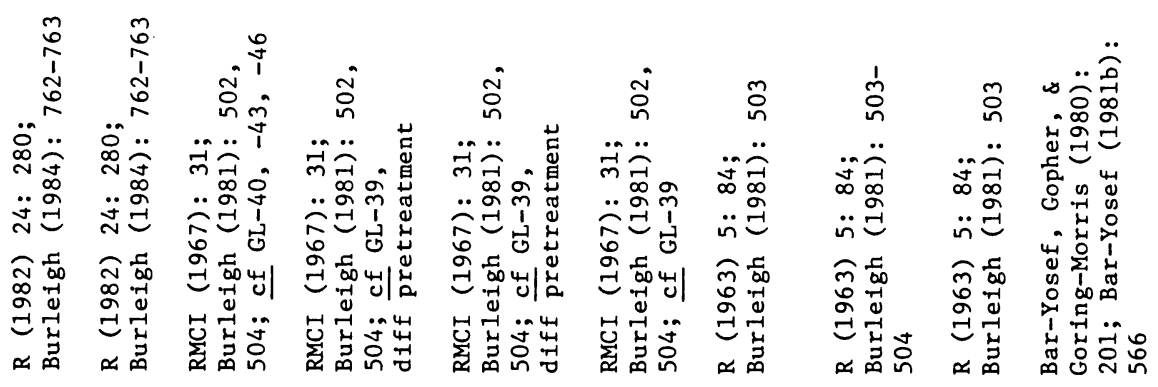

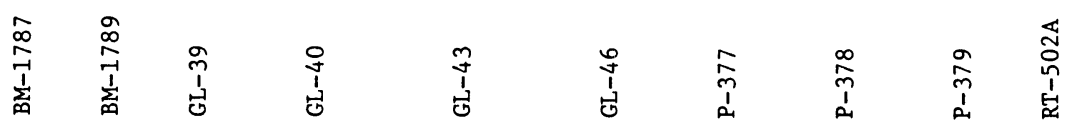

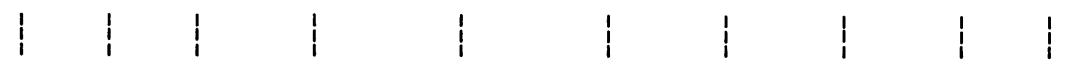

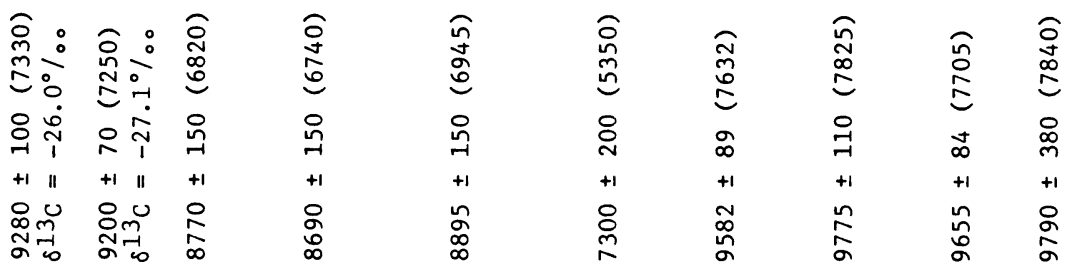

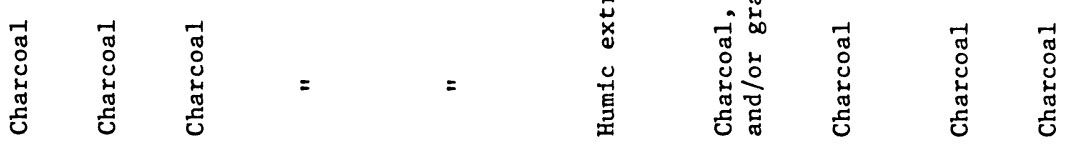

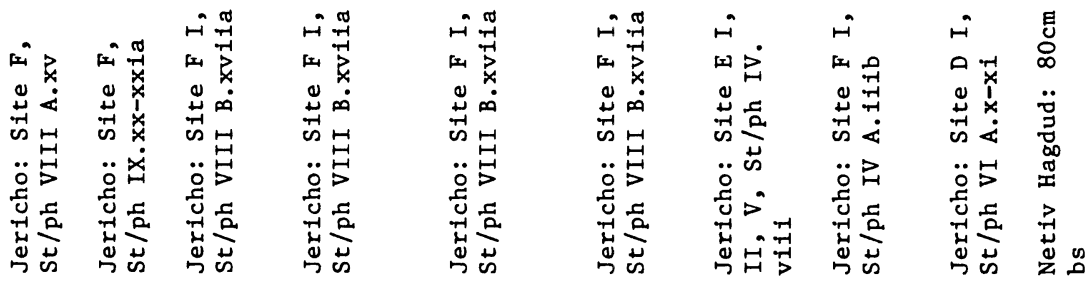




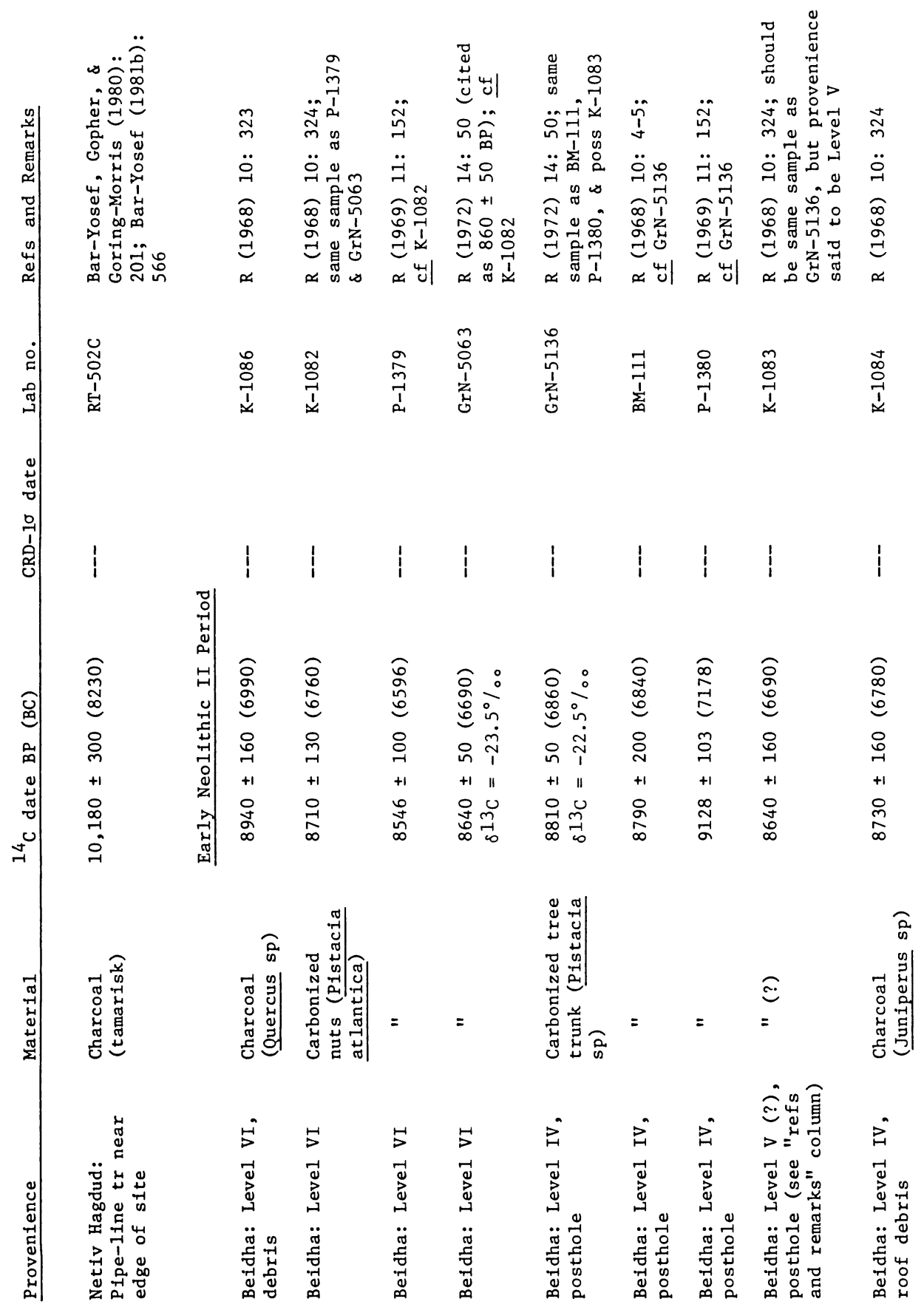




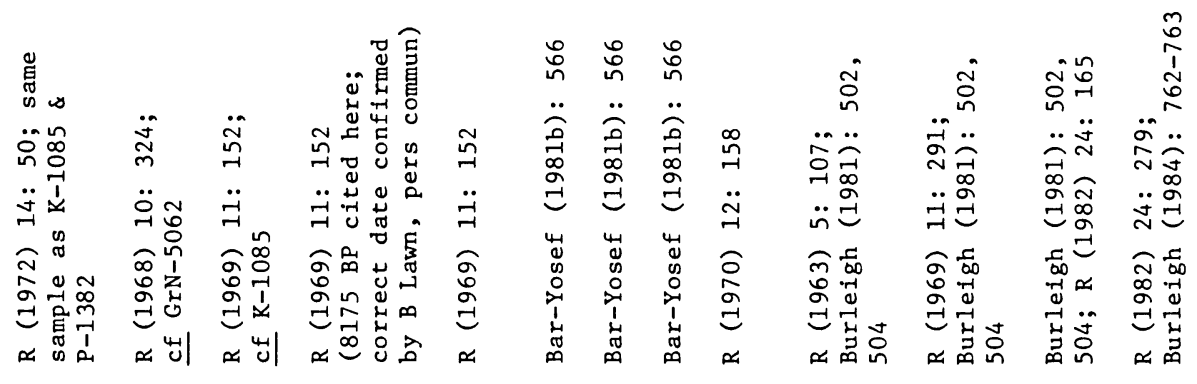

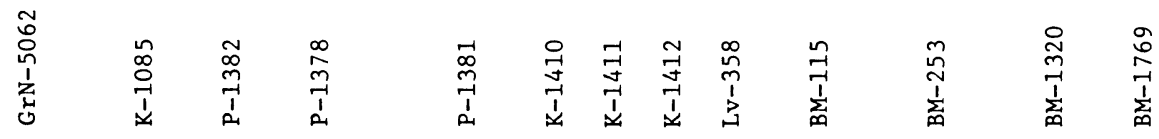

O

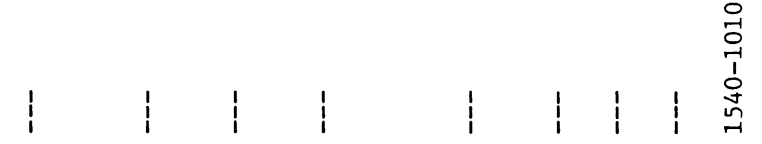

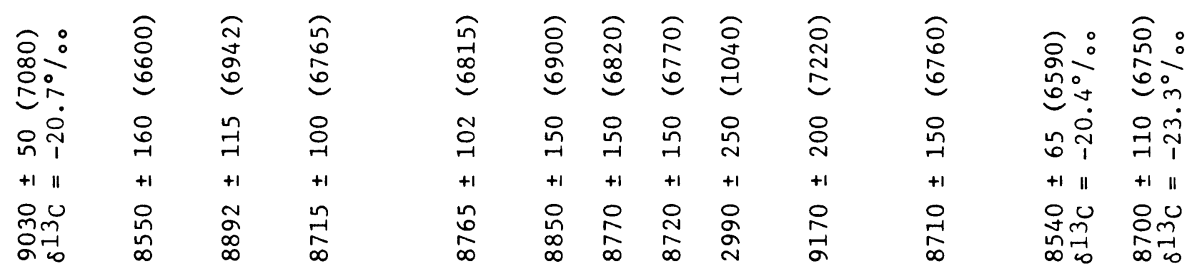

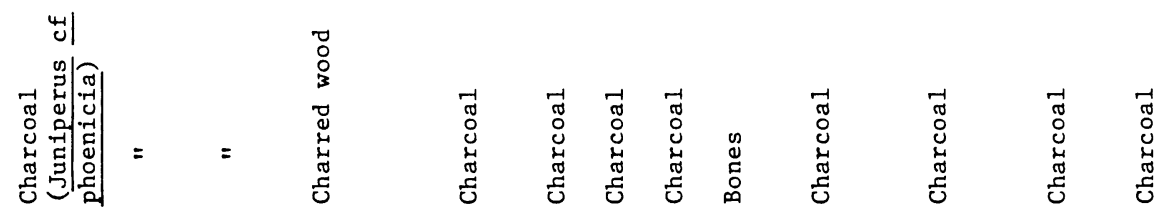

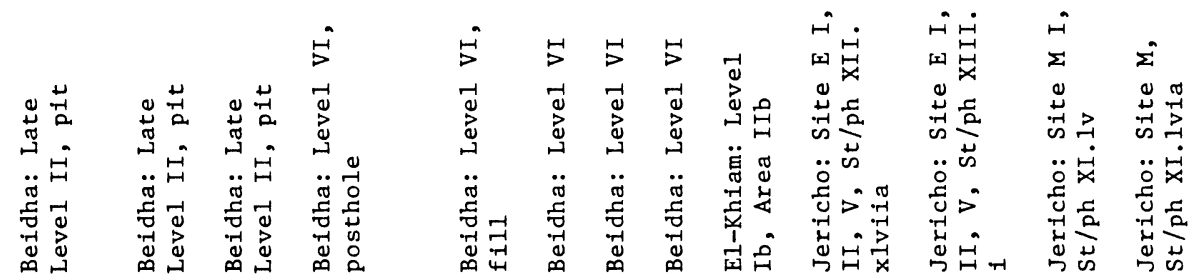




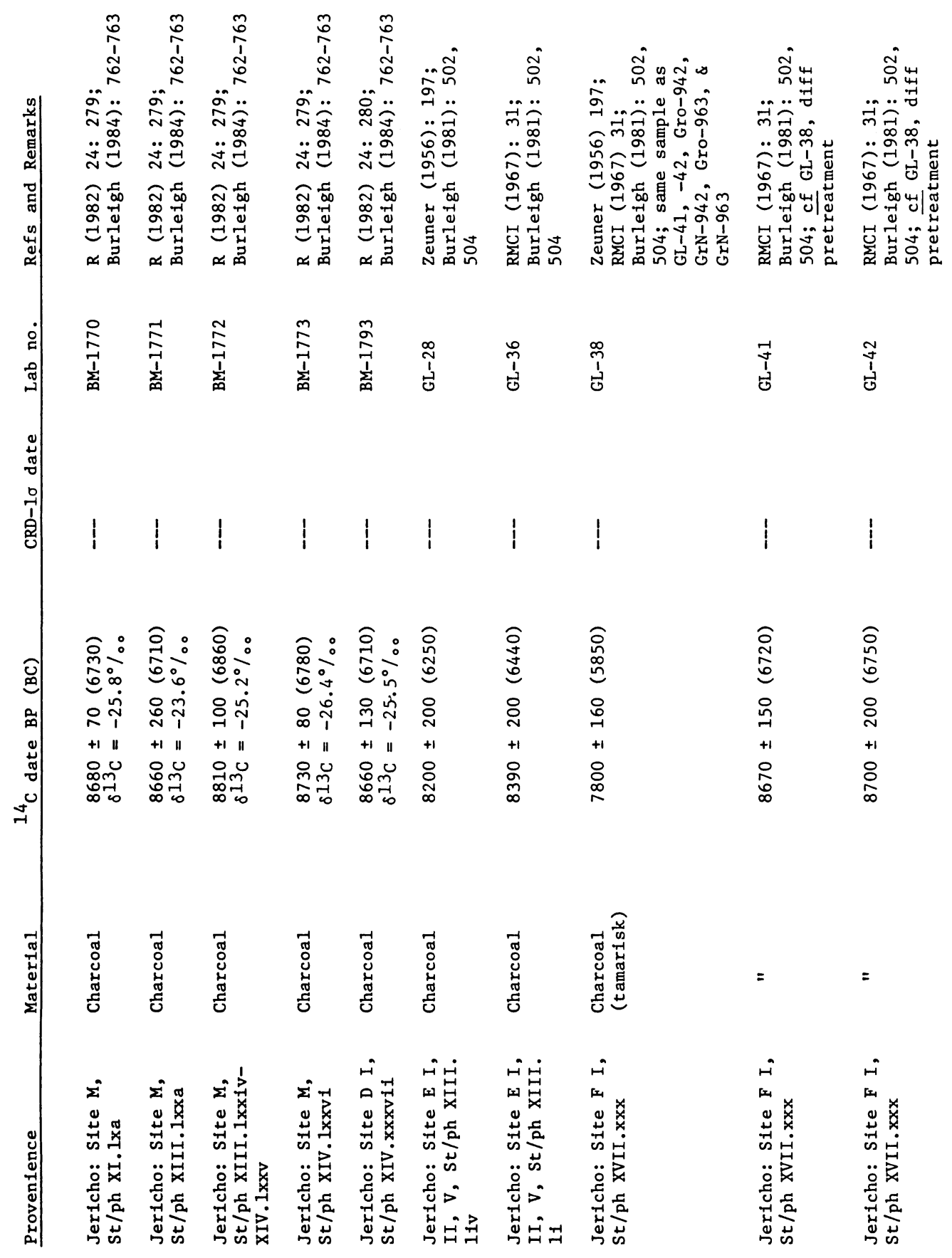




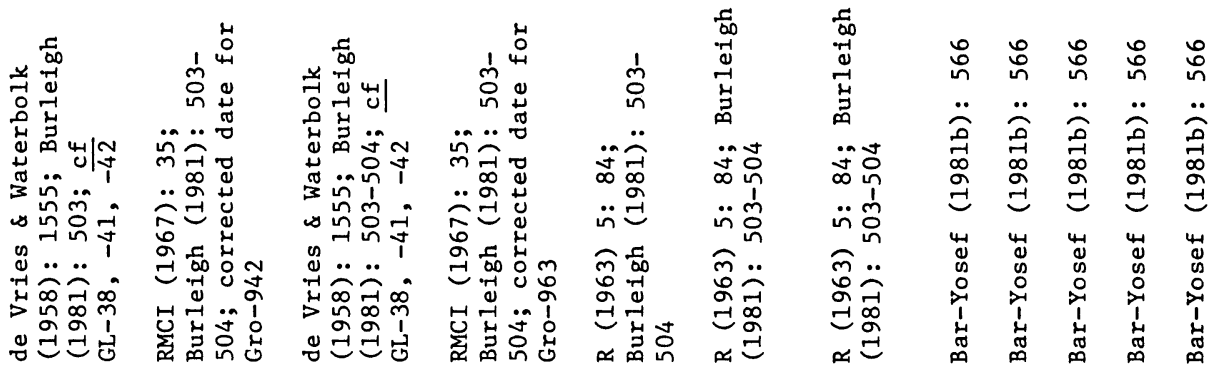

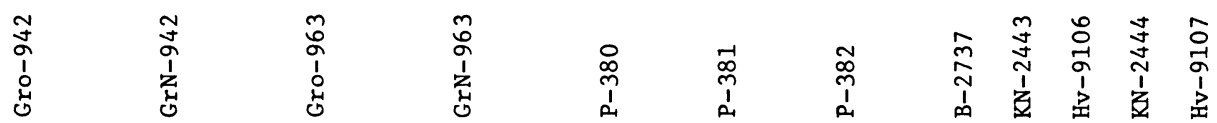

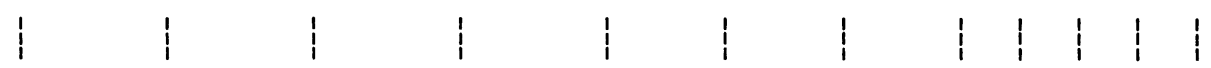

\begin{tabular}{|c|c|c|c|c|c|c|c|c|c|c|}
\hline $\begin{array}{l}\text { ô } \\
\text { مू } \\
\text { ర్ర }\end{array}$ & 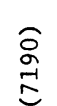 & 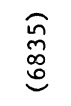 & 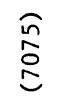 & $\begin{array}{l}\hat{o} \\
\text { \& } \\
\text { o }\end{array}$ & 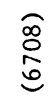 & ڤ్̊ & 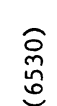 & $\begin{array}{l}\text { స్ } \\
\text { త్ర }\end{array}$ & $\begin{array}{l}\text { ᄋ్ } \\
\text { O্ర }\end{array}$ & $\begin{array}{l}0 \\
0 \\
0 \\
0 \\
0\end{array}$ \\
\hline 0 & 웅 & $\underset{-1}{\stackrel{1}{0}}$ & $\stackrel{-}{\circ}$ & n & $\overrightarrow{0}$ & ח̊요 & হ̌ & $\stackrel{n}{n}$ & n & \\
\hline & +1 & +1 & +1 & +1 & +1 & +1 & +1 & +1 & +1 & \\
\hline & 号 & $\stackrel{\infty}{\infty}$ & $\stackrel{\tilde{N}}{0}$ & $\rightarrow$ & $\stackrel{\infty}{n}$ & ڤั & $\infty$ & 웅 & 京 & $\underset{\infty}{\stackrel{0}{D_{\infty}}}$ \\
\hline
\end{tabular}

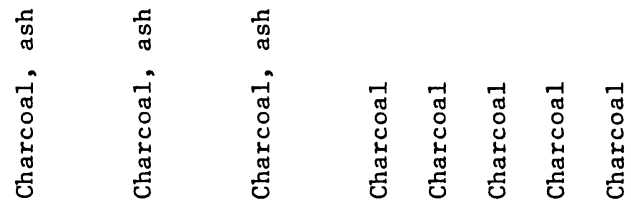

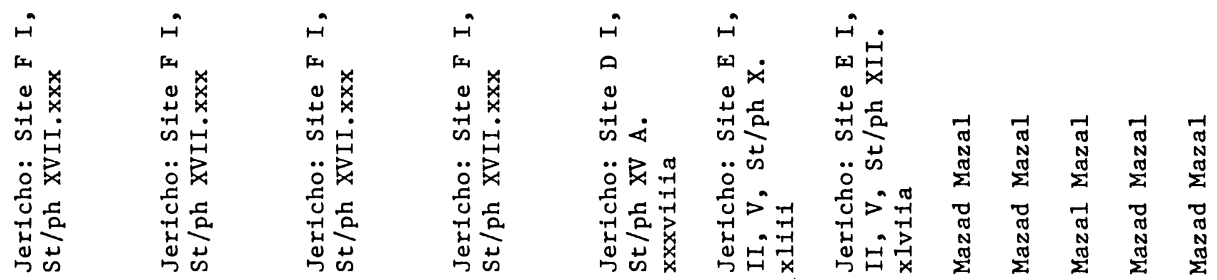




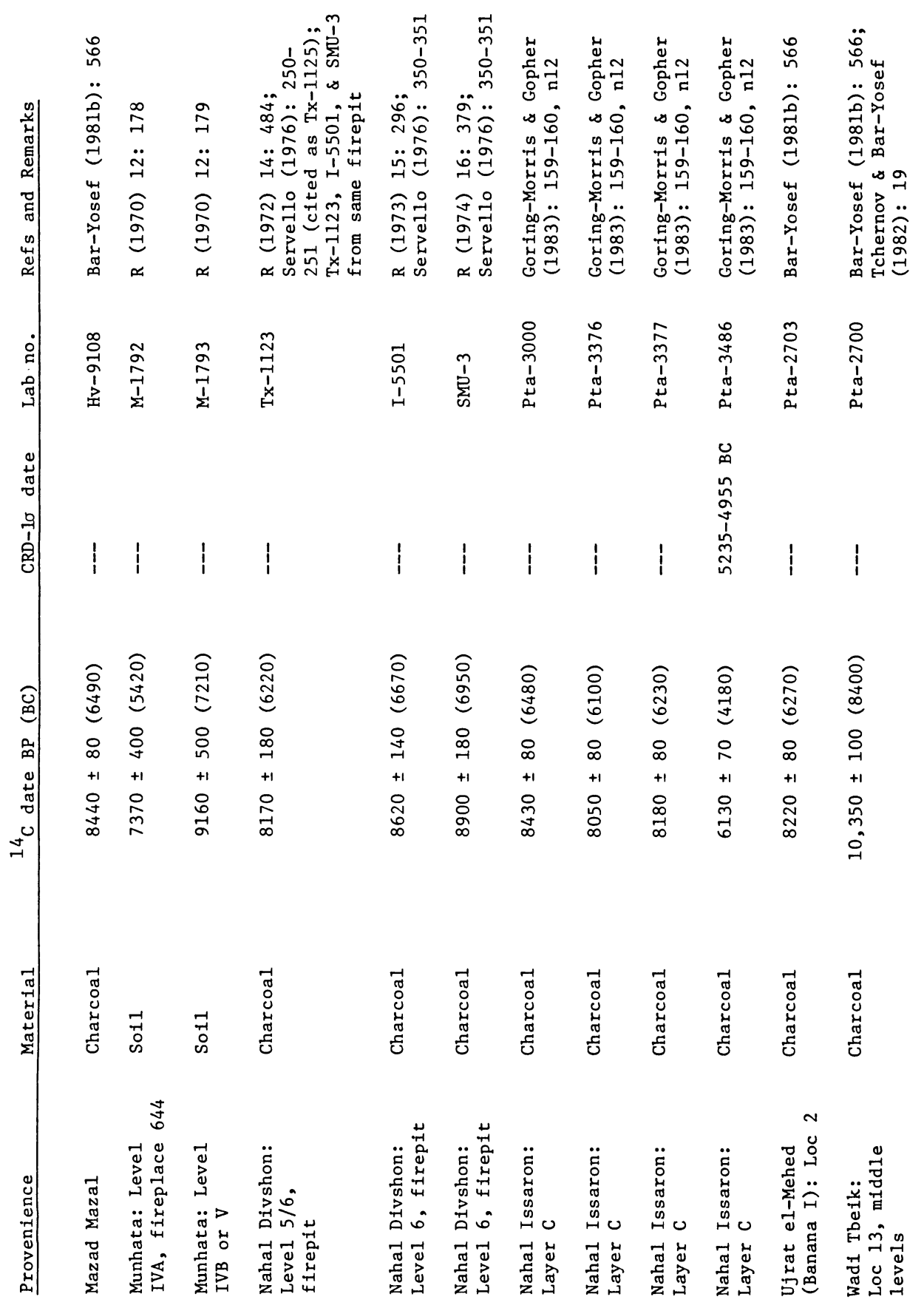




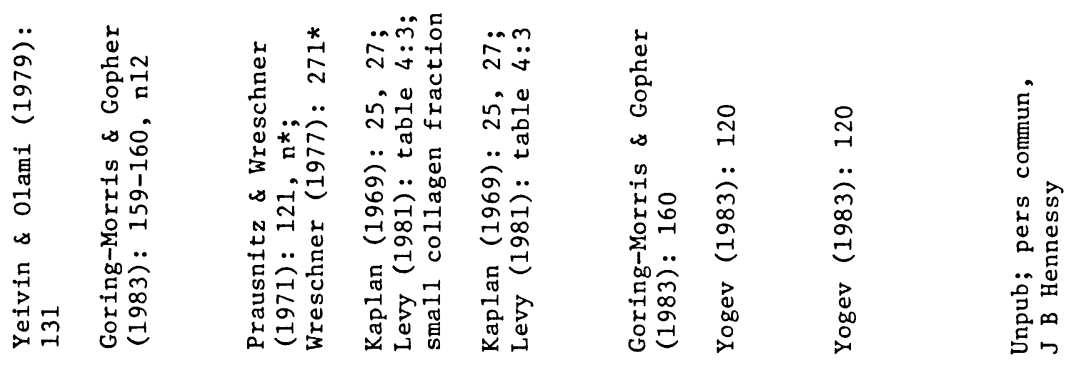

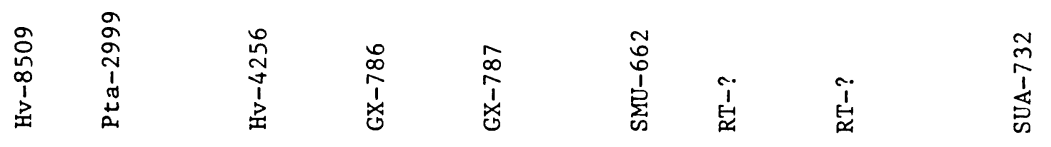

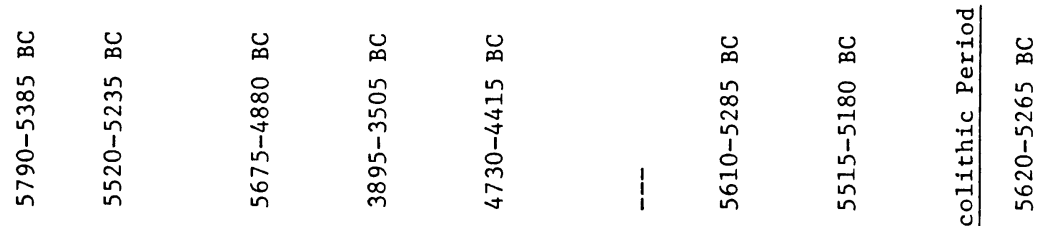

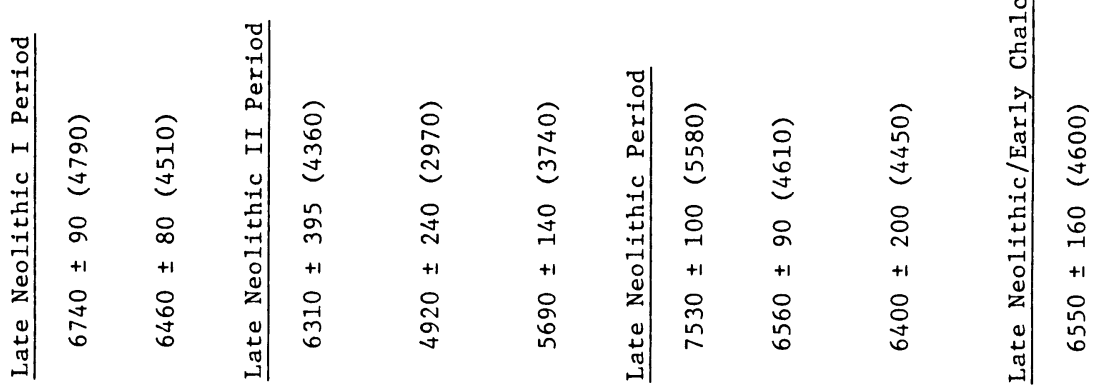

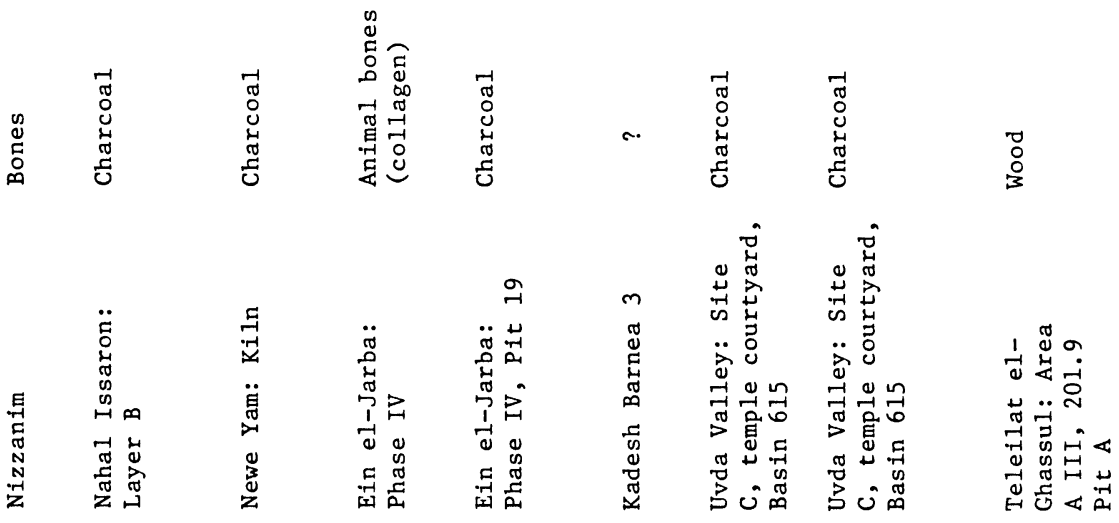




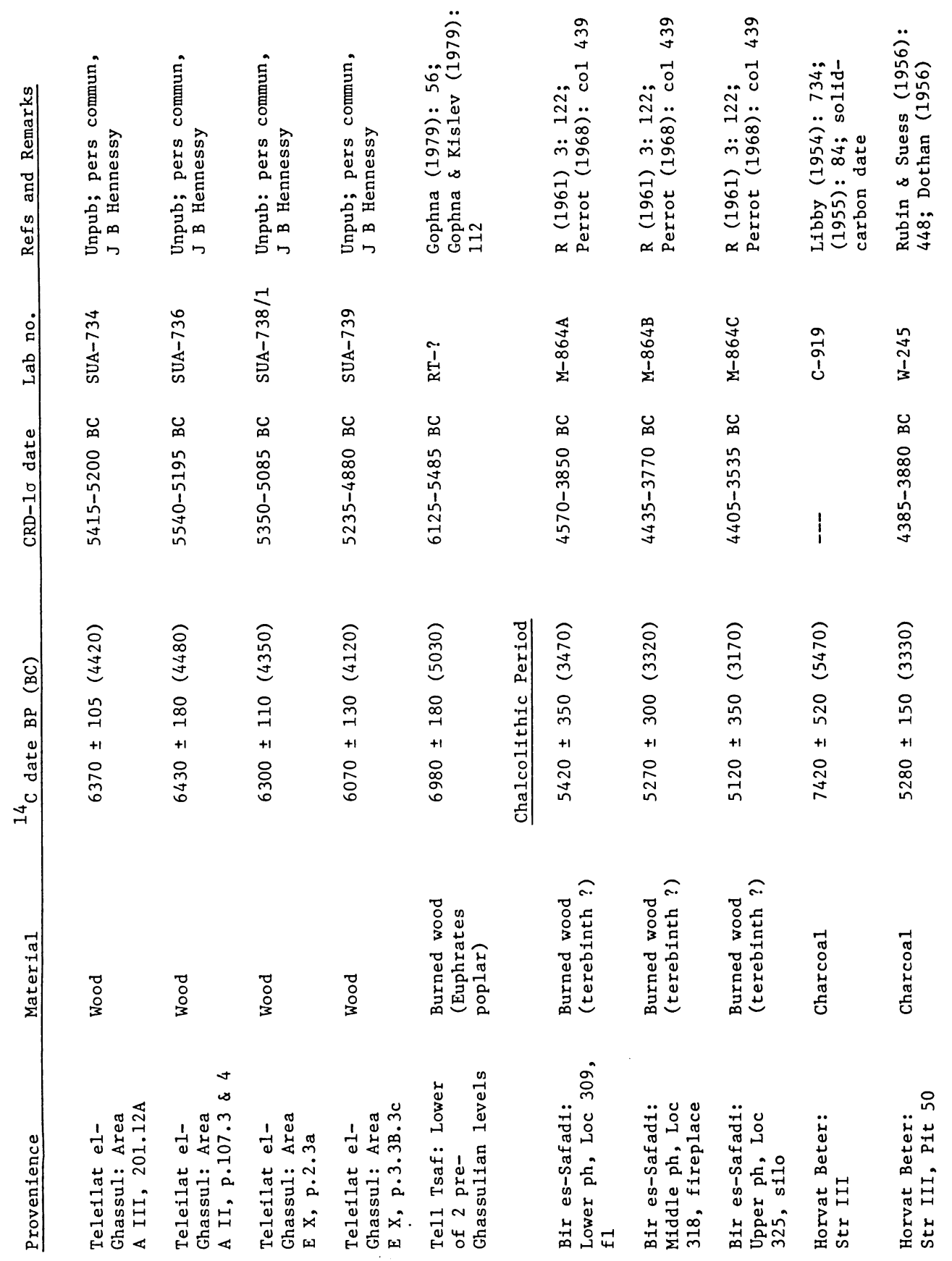




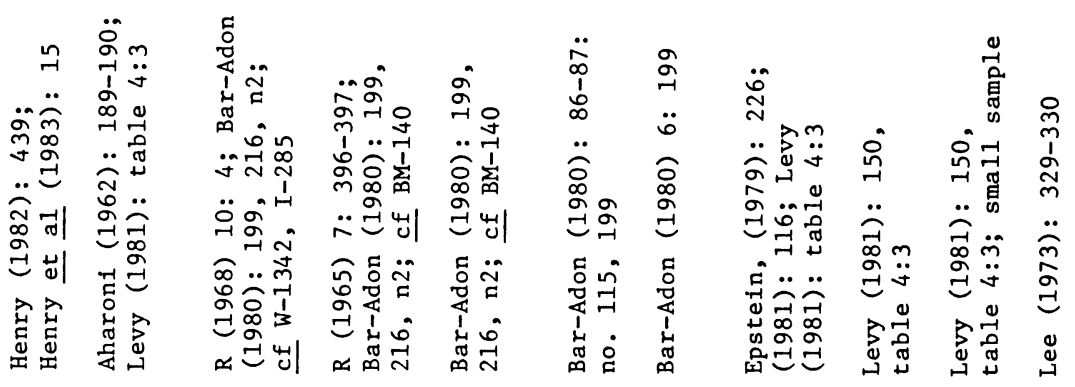

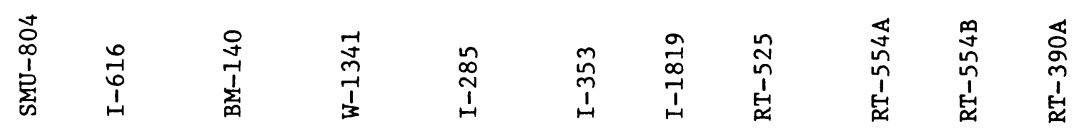

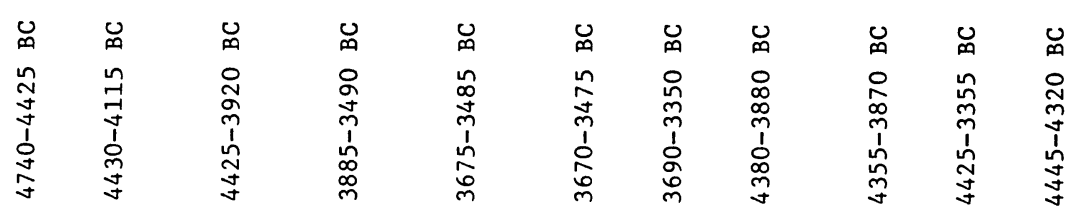

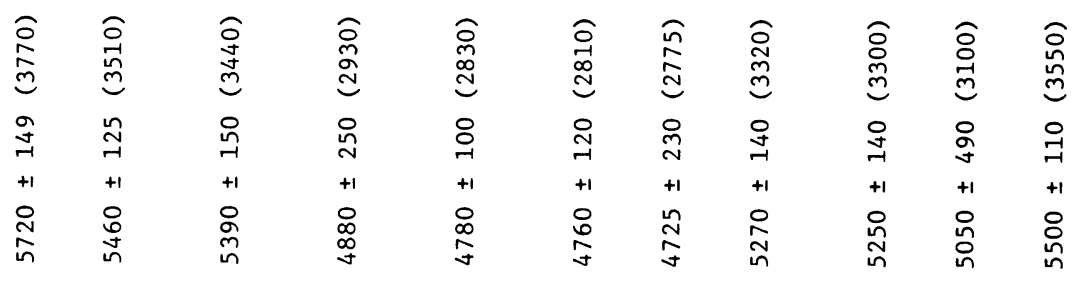

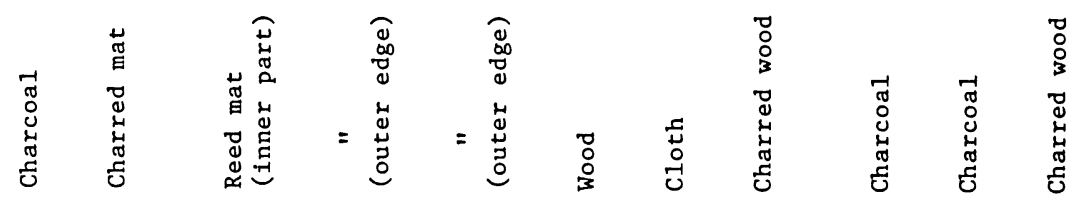

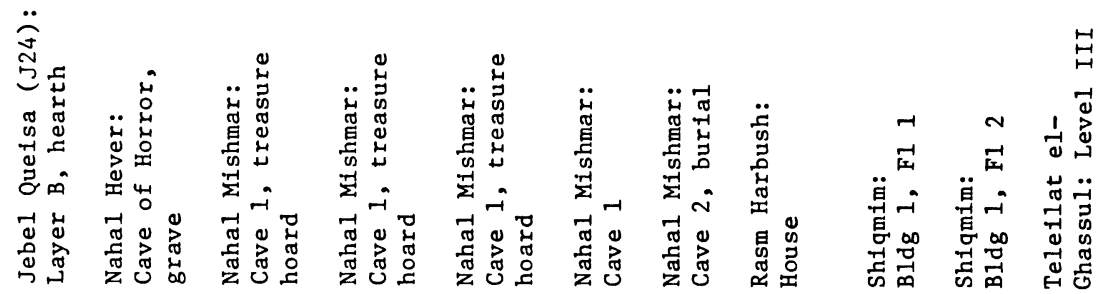




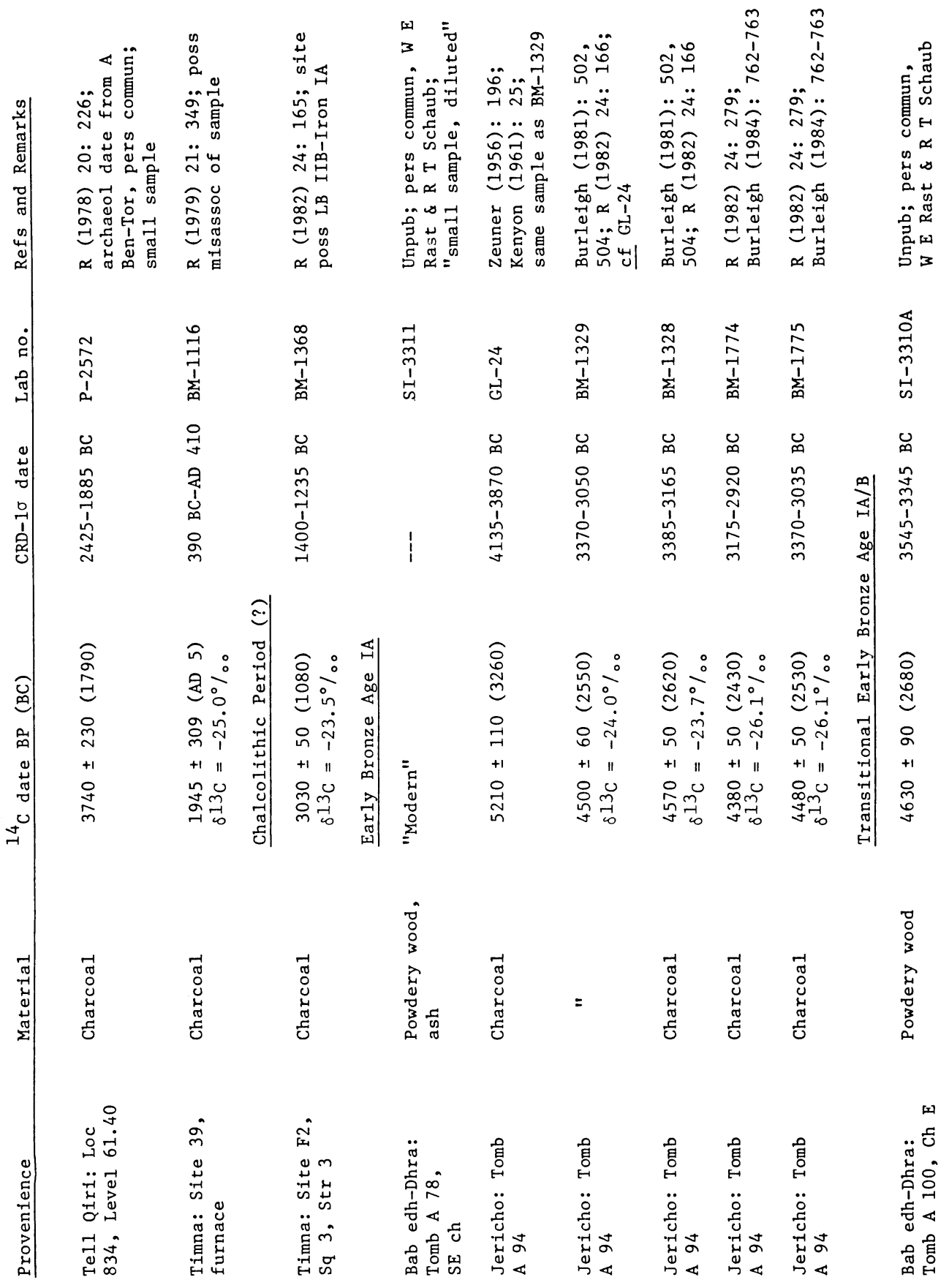




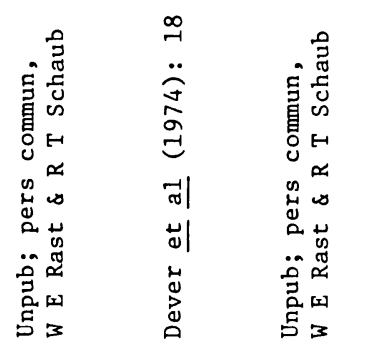

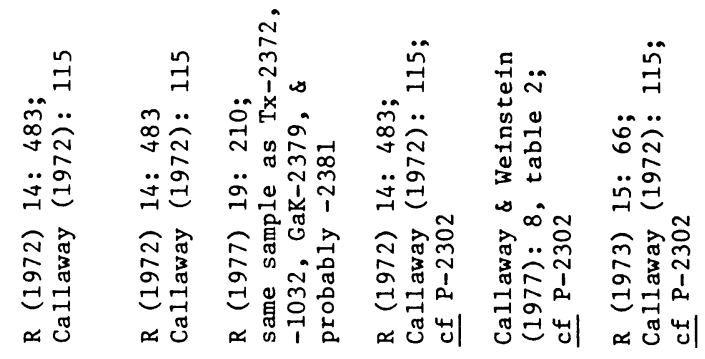

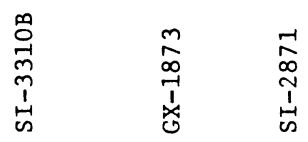

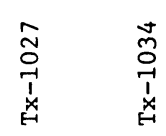

ָे

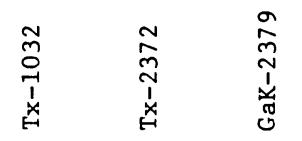

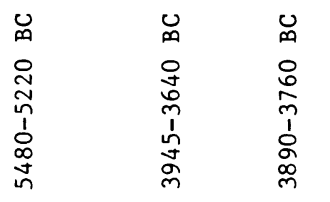

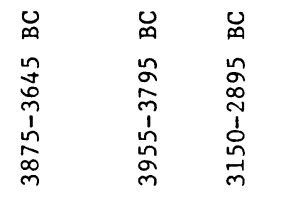

邑

$\begin{array}{ccc} & & \\ 0 & 0 & 0 \\ 0 & 0 & 0 \\ m & \infty & 0 \\ i & \vdots & \vdots \\ 0 & \vdots & 0 \\ \infty & m & \infty \\ m & m & m\end{array}$

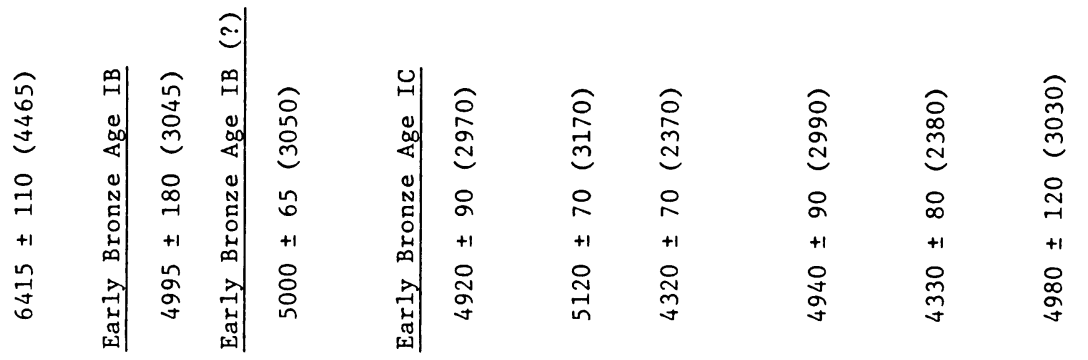

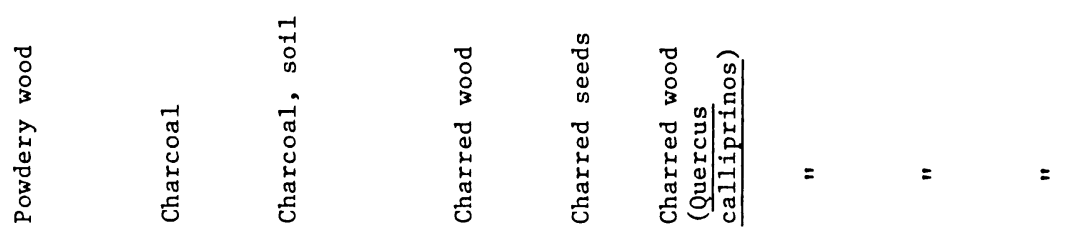

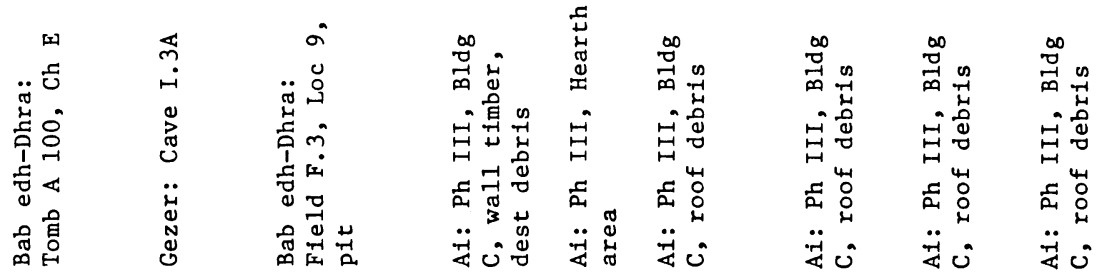




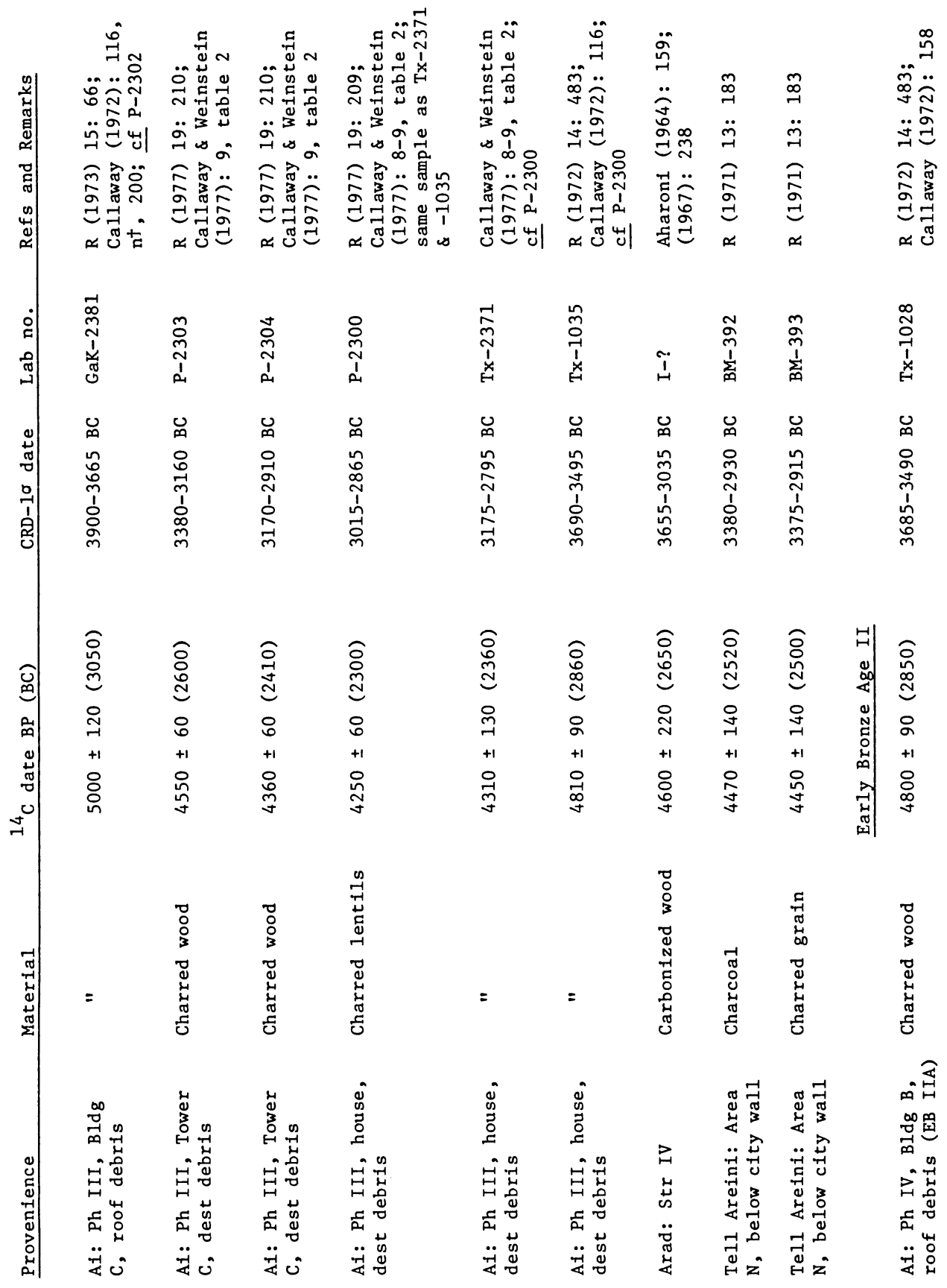




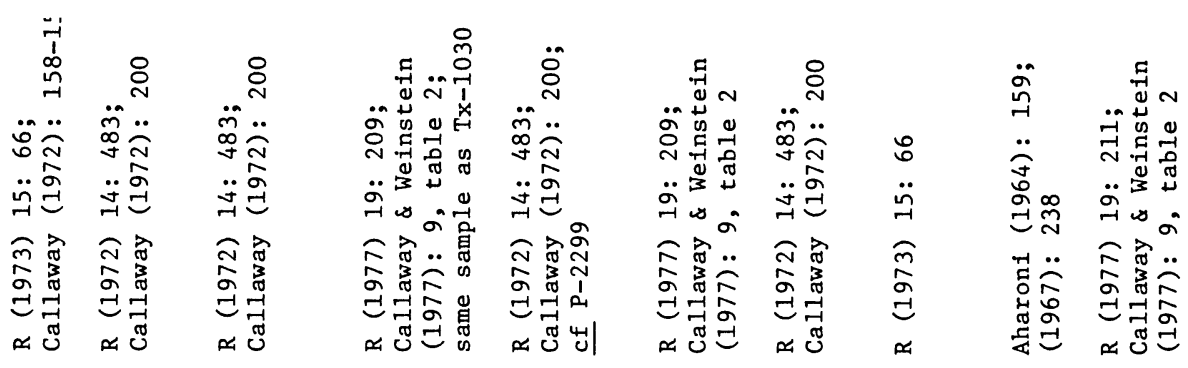

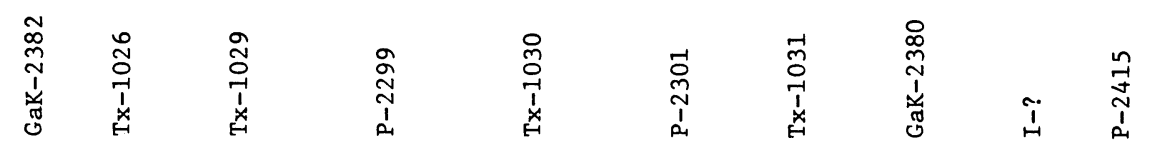

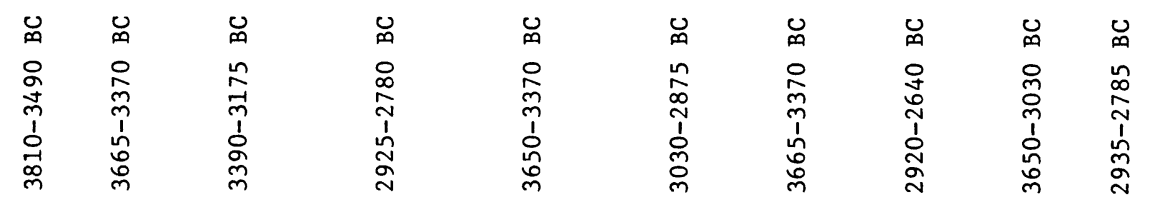

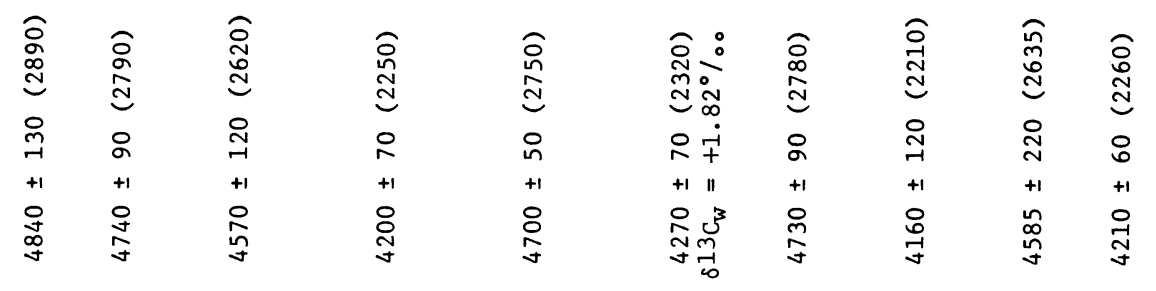

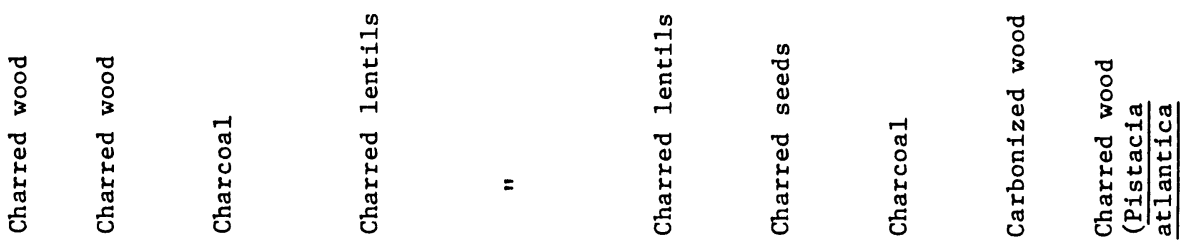

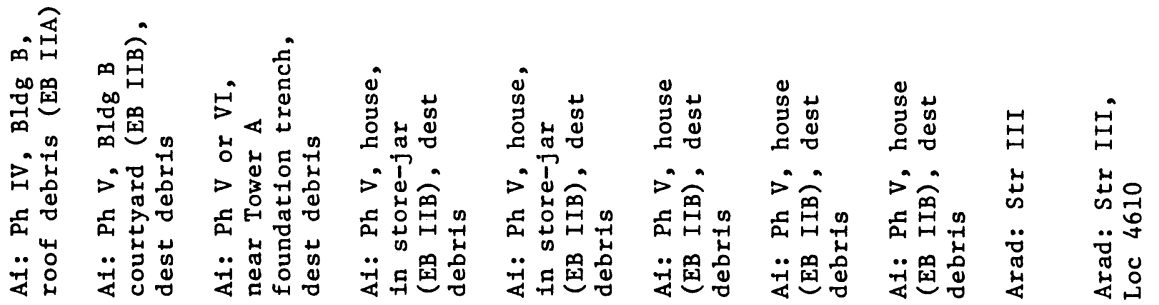




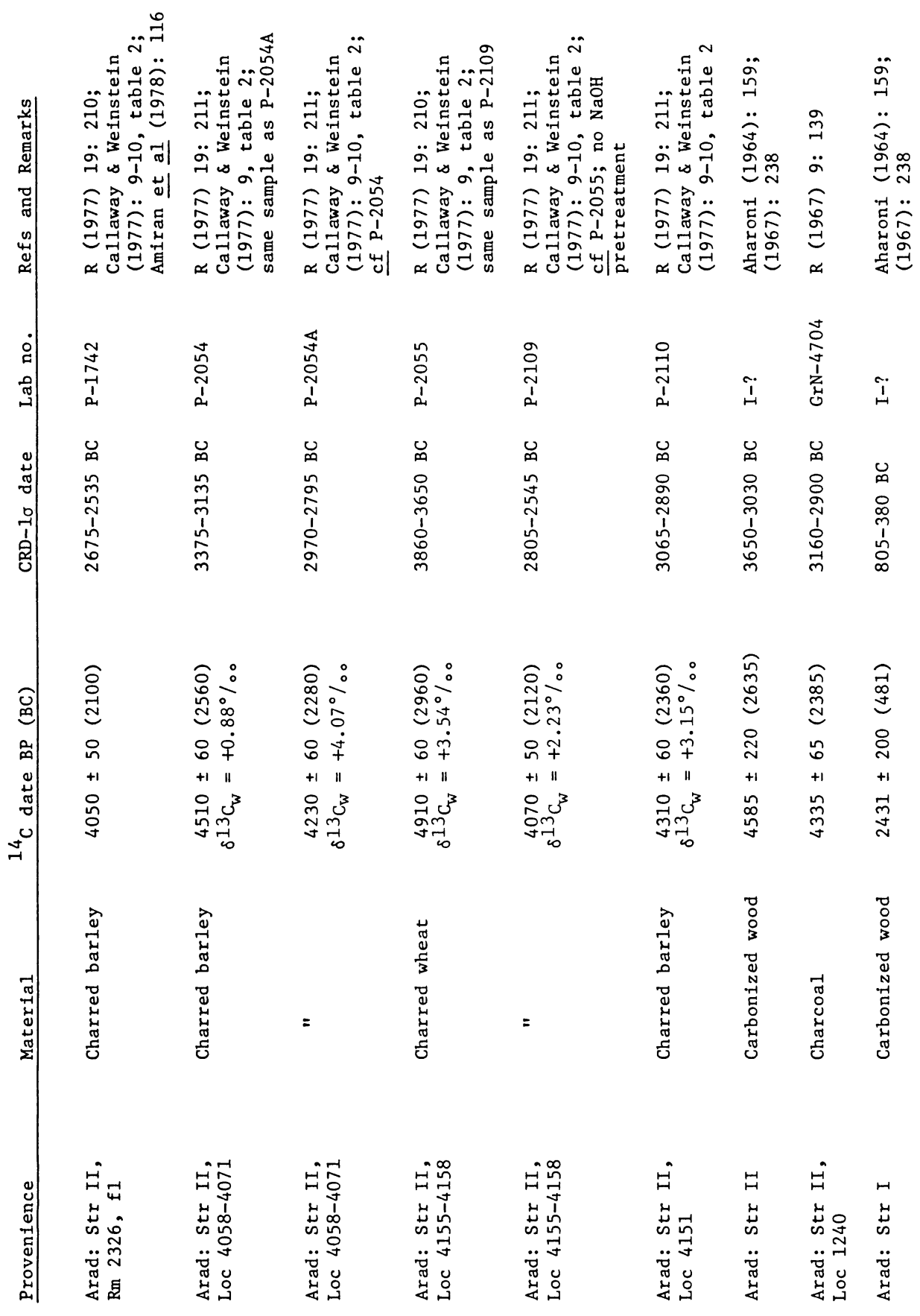




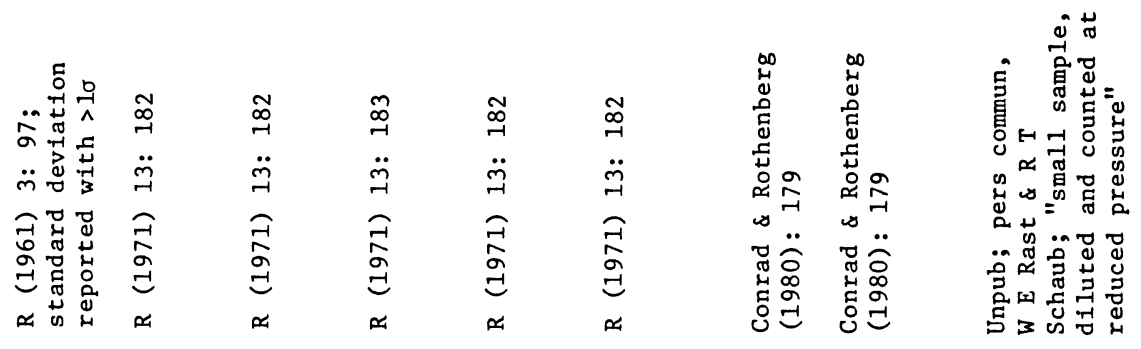

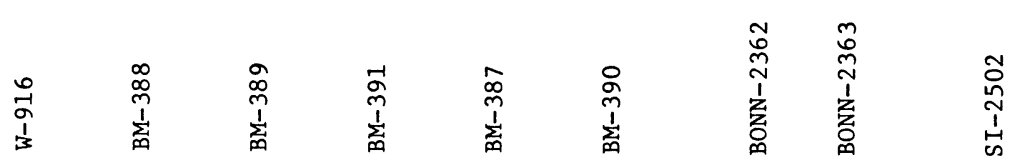

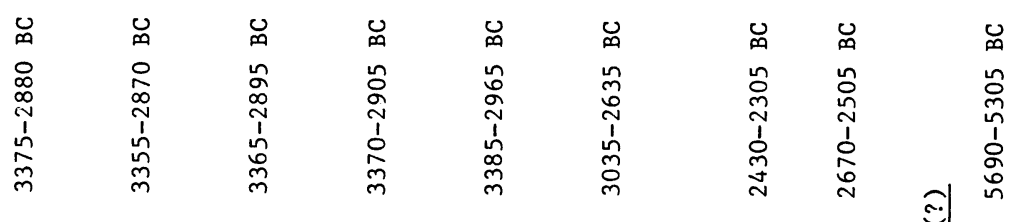

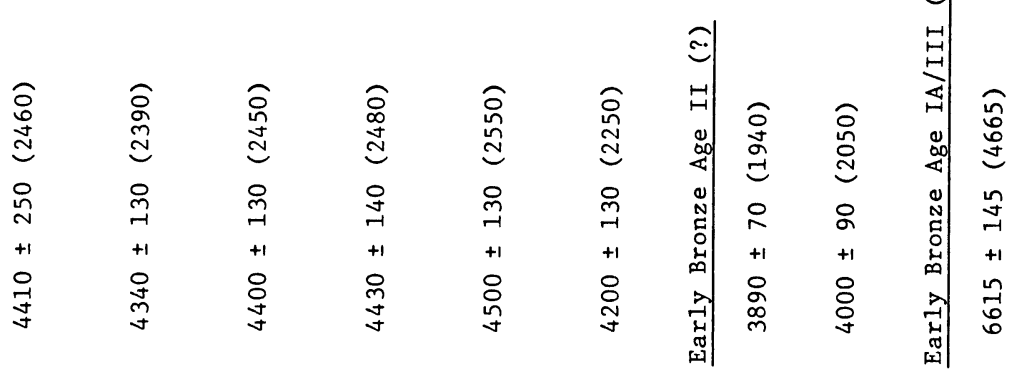

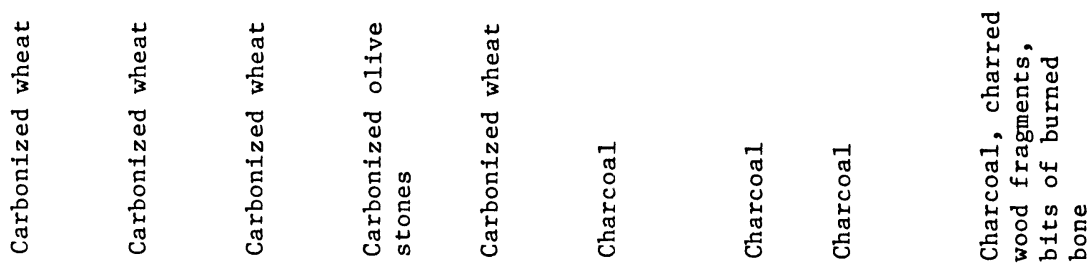

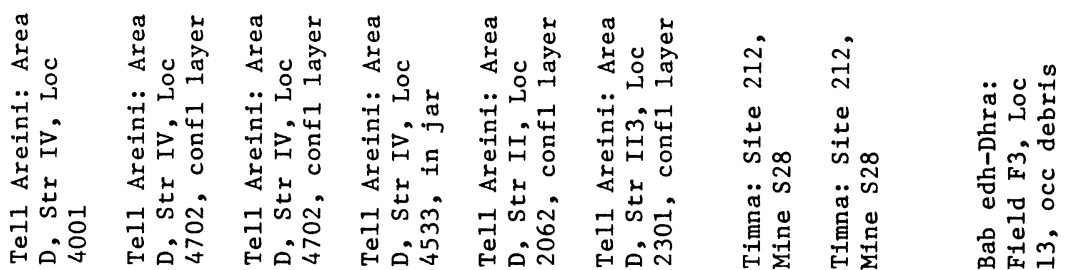




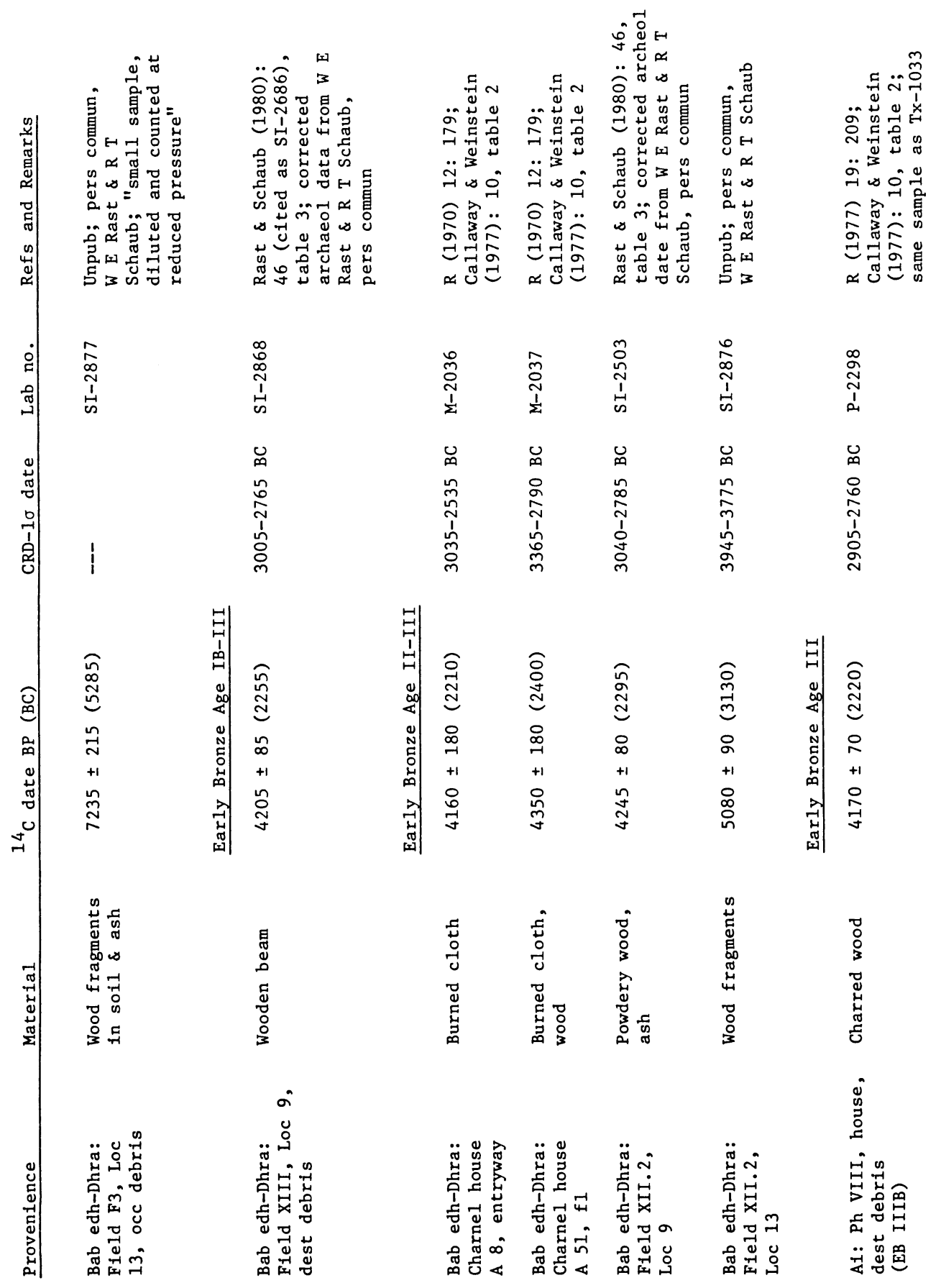




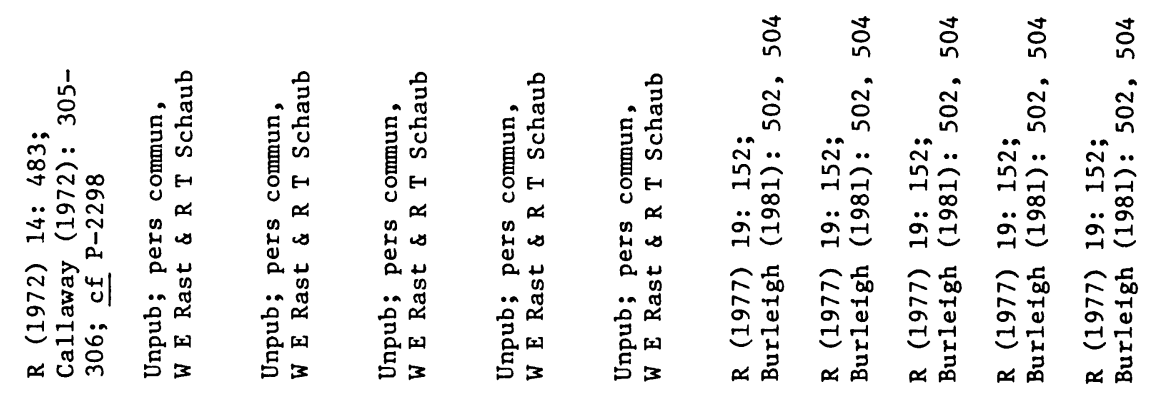

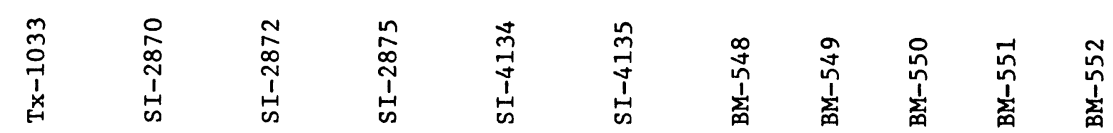

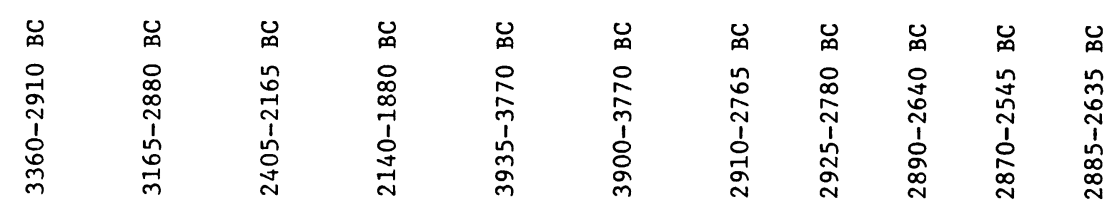

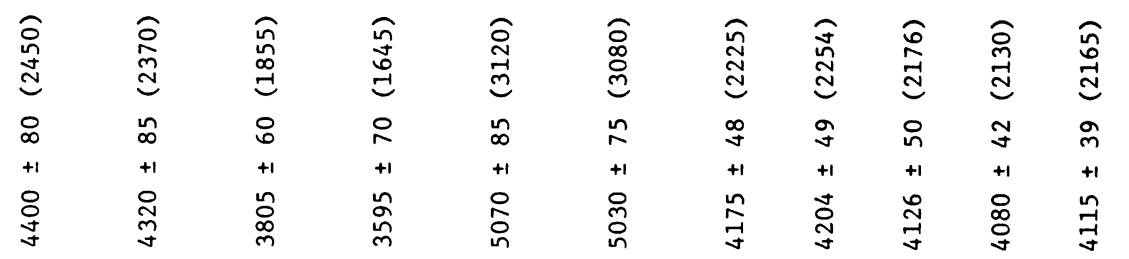

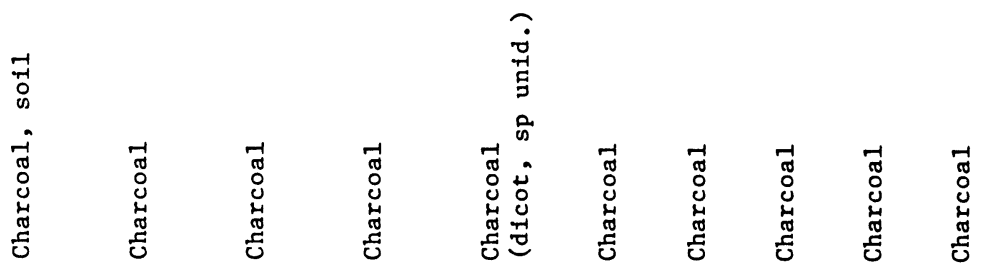

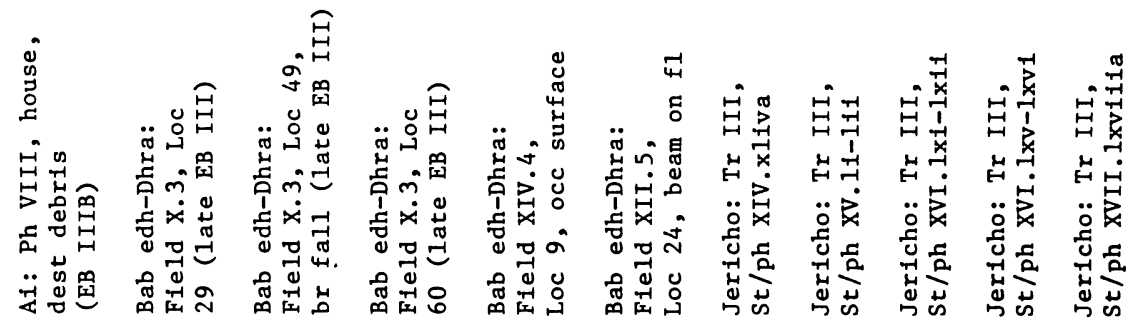




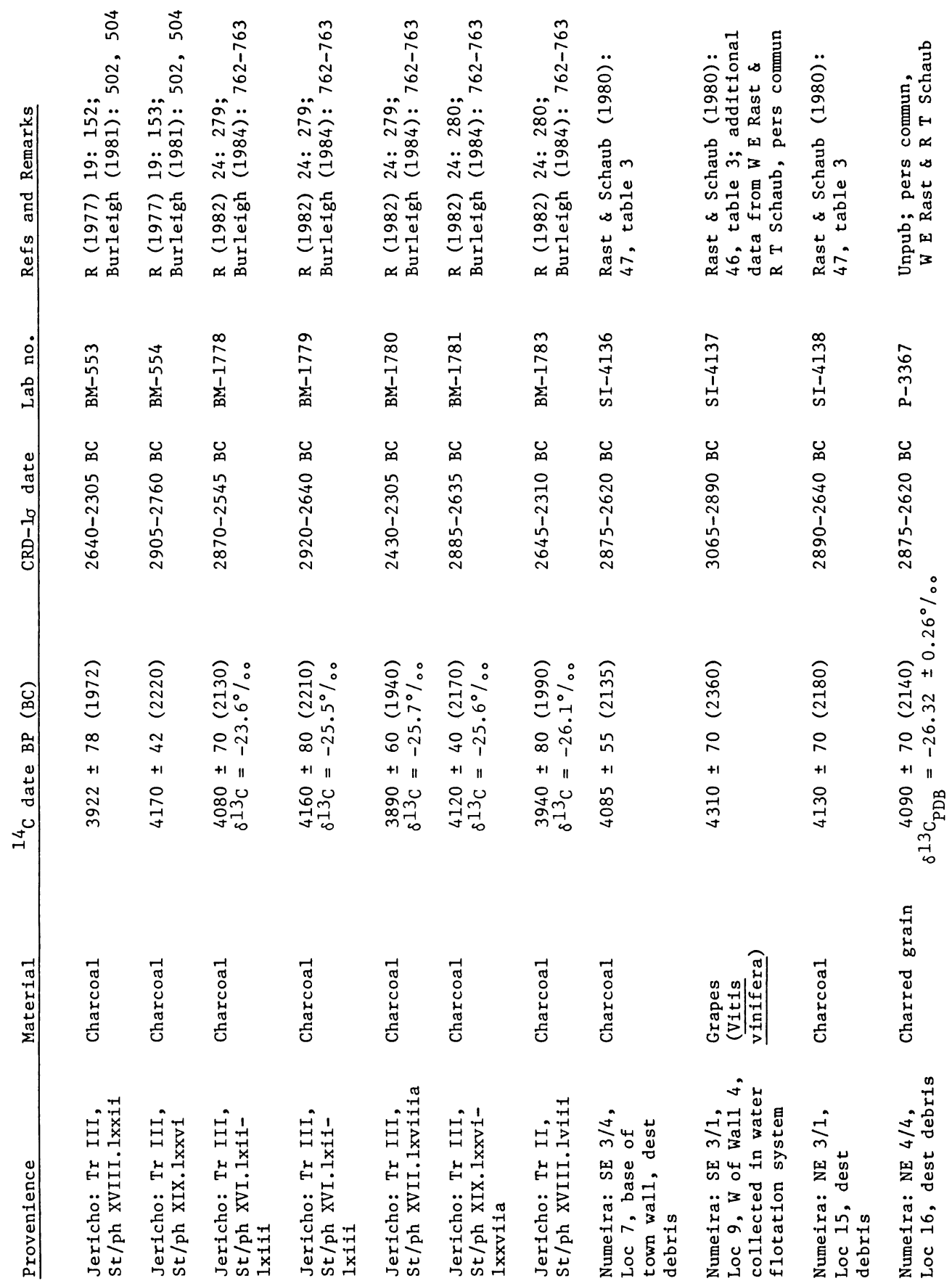




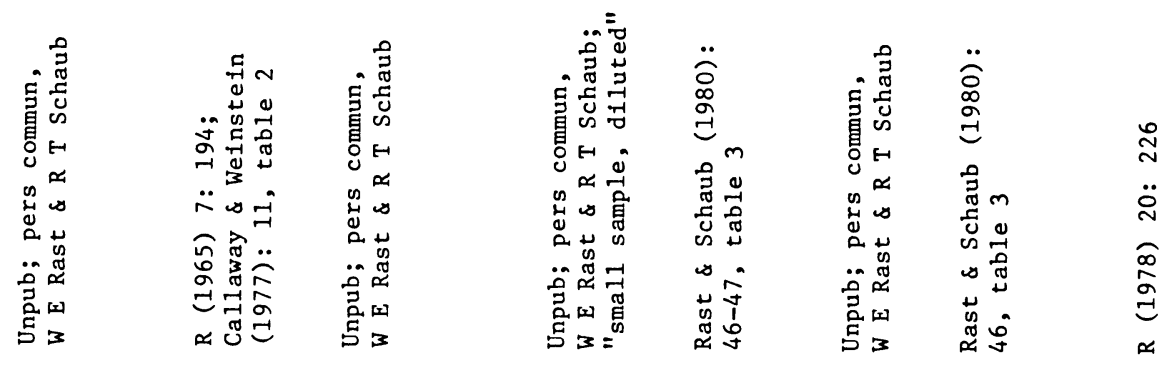

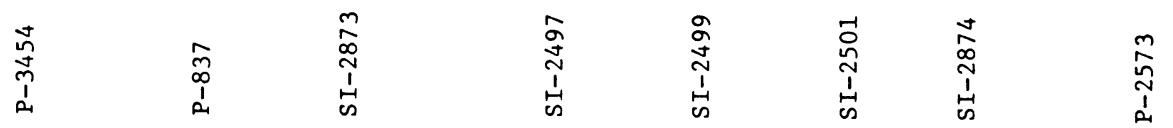

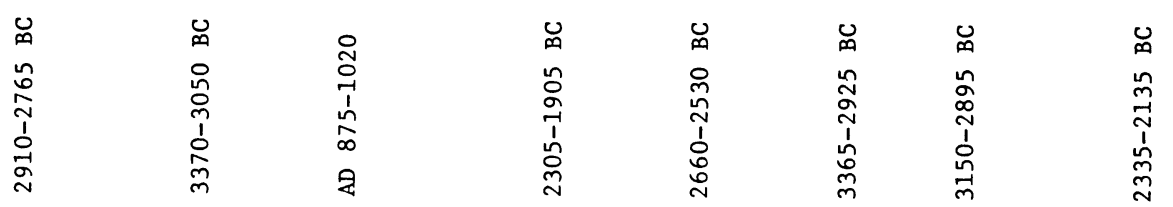

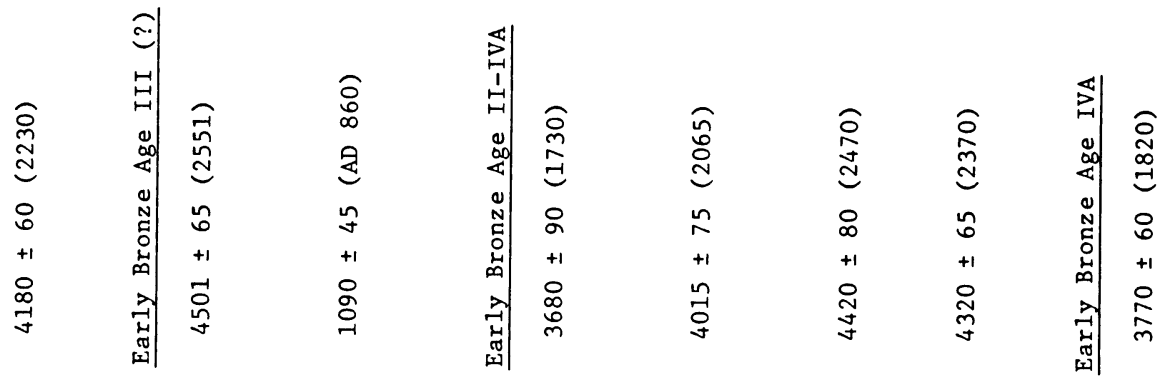

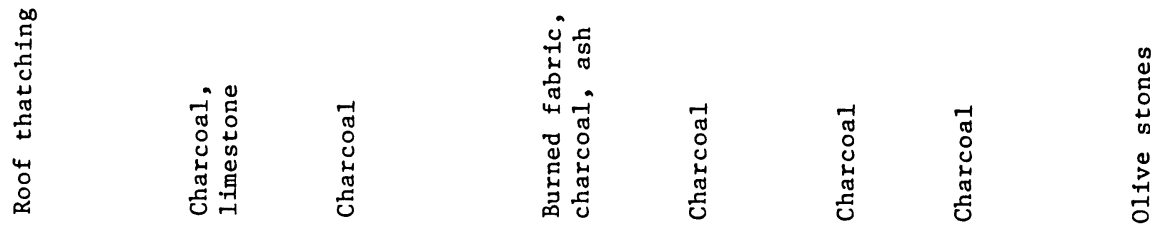

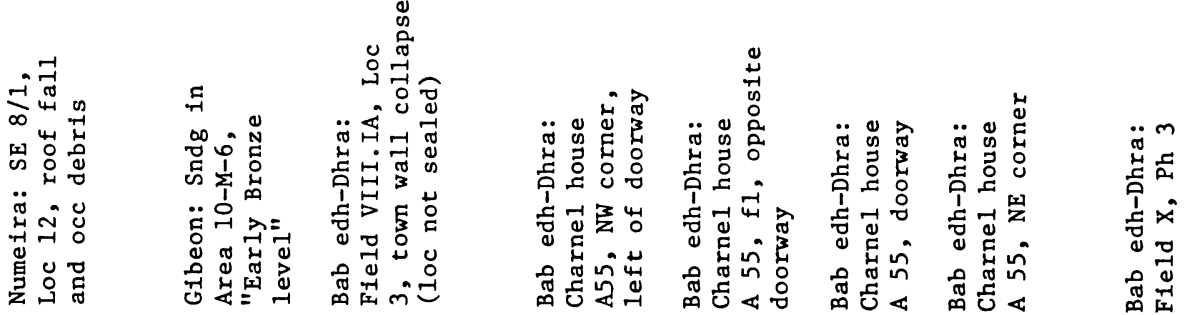




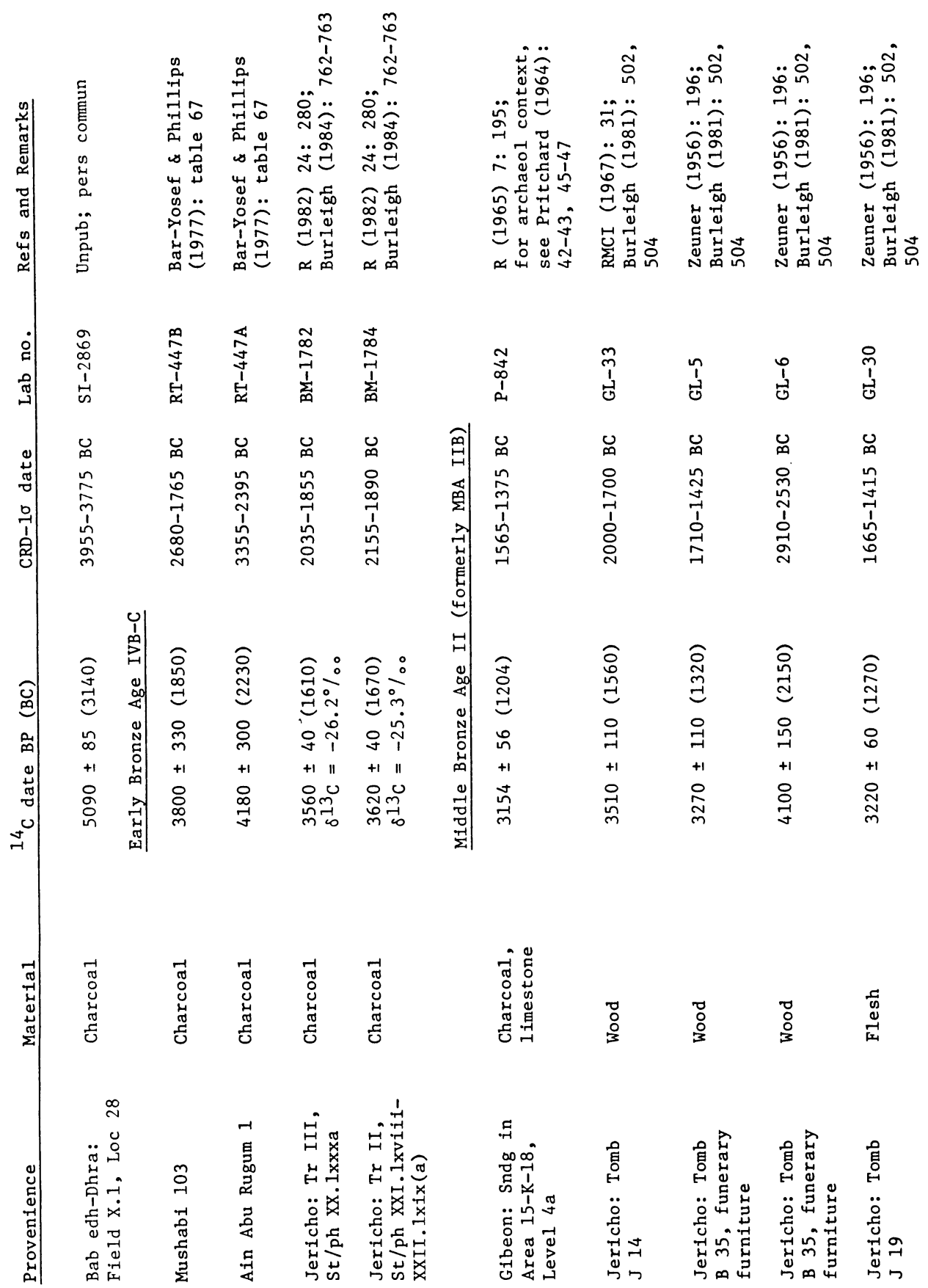




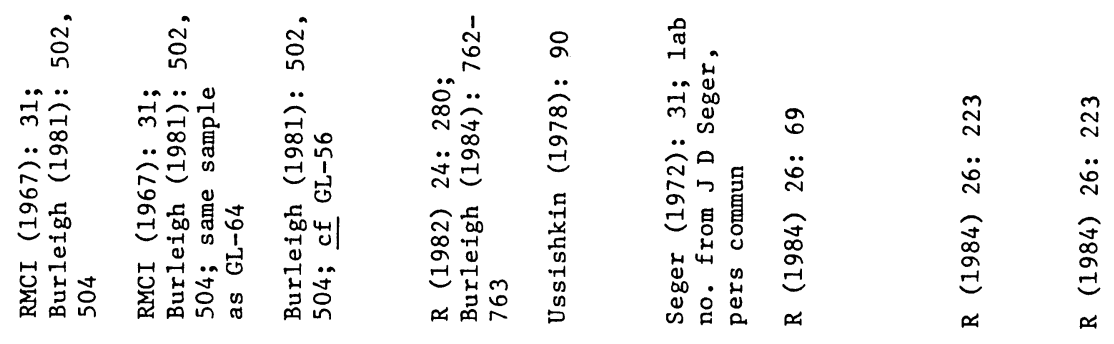

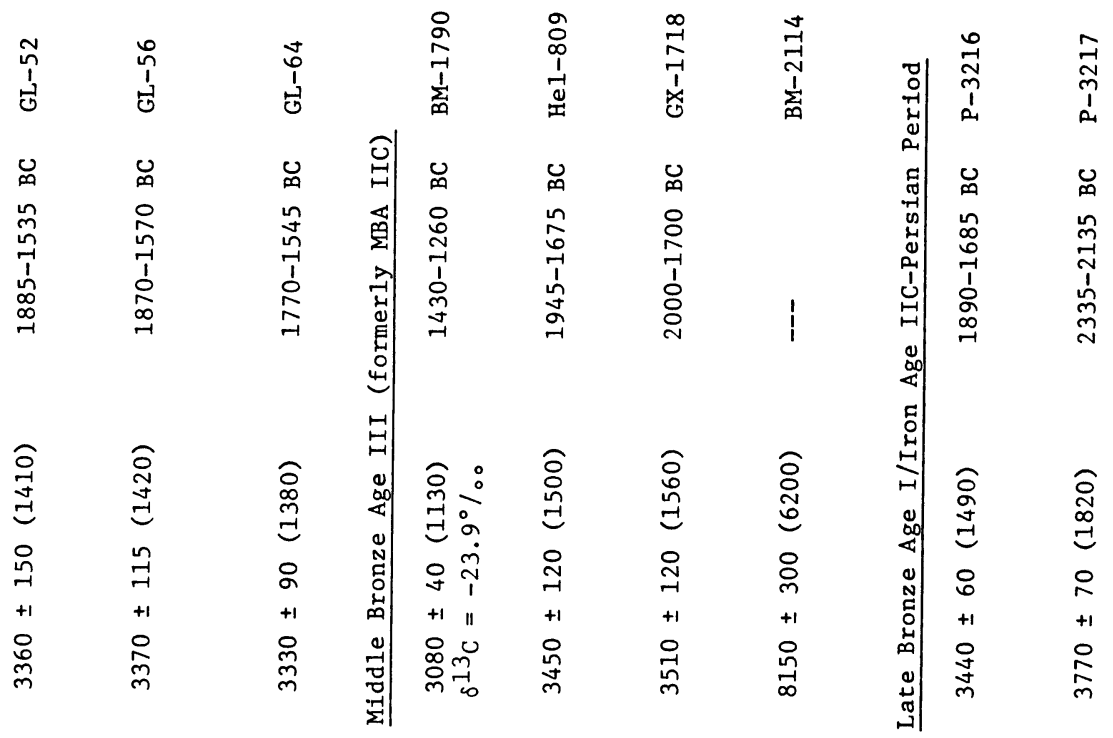

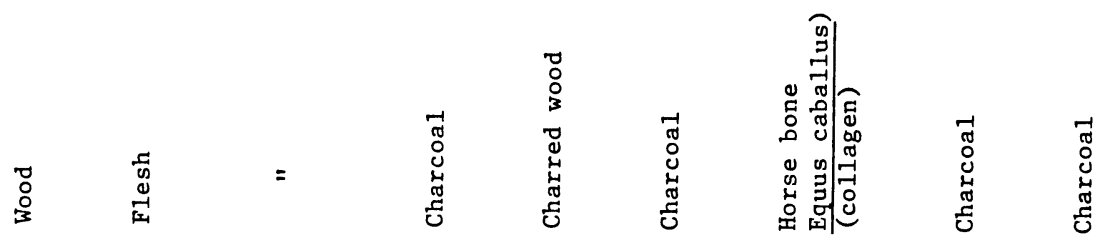

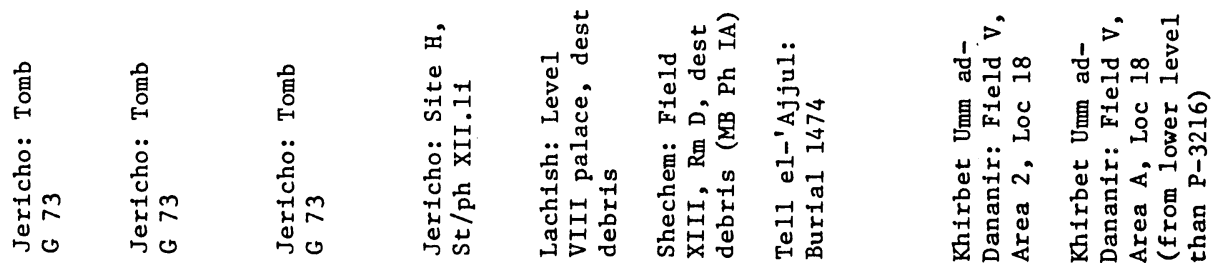




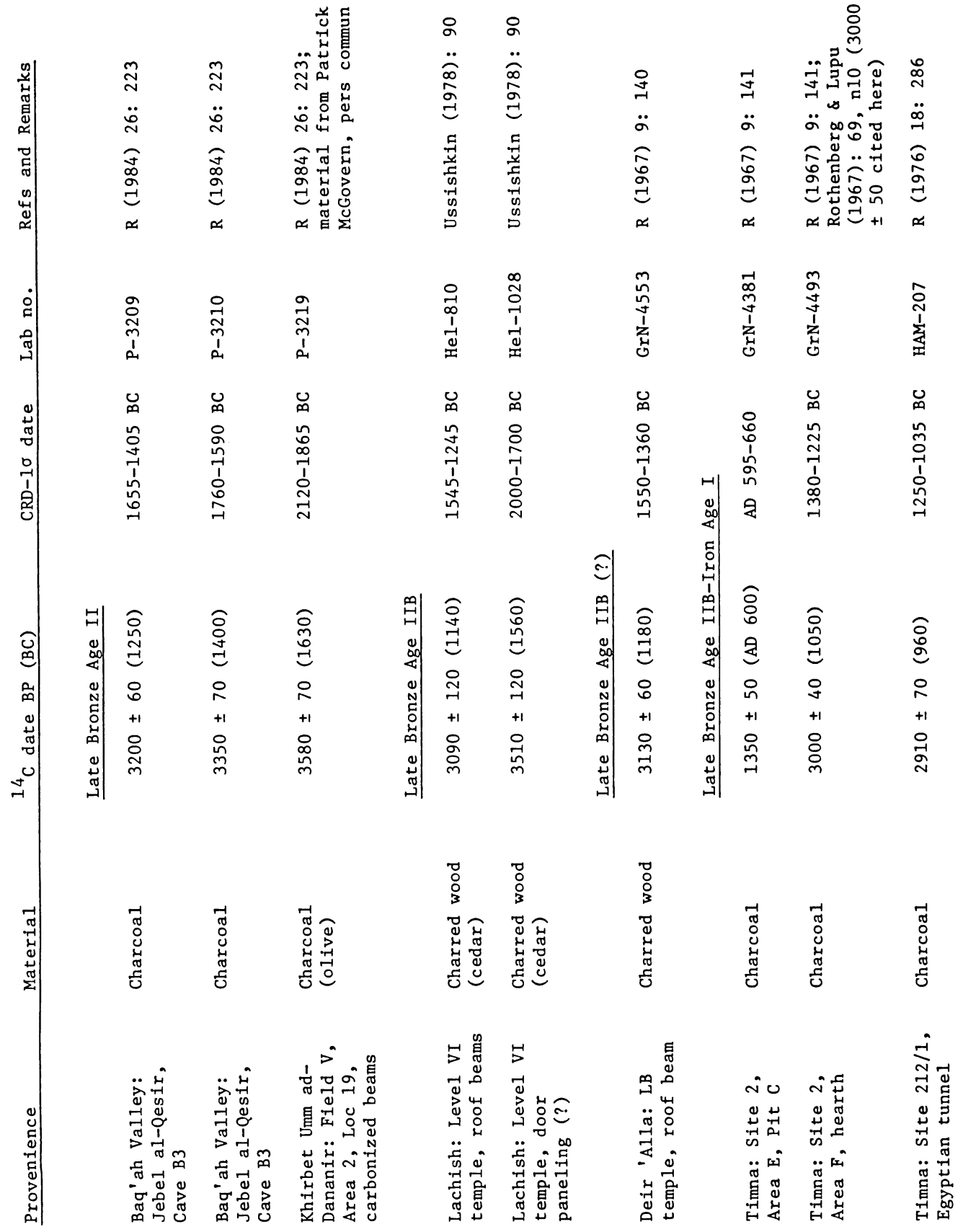




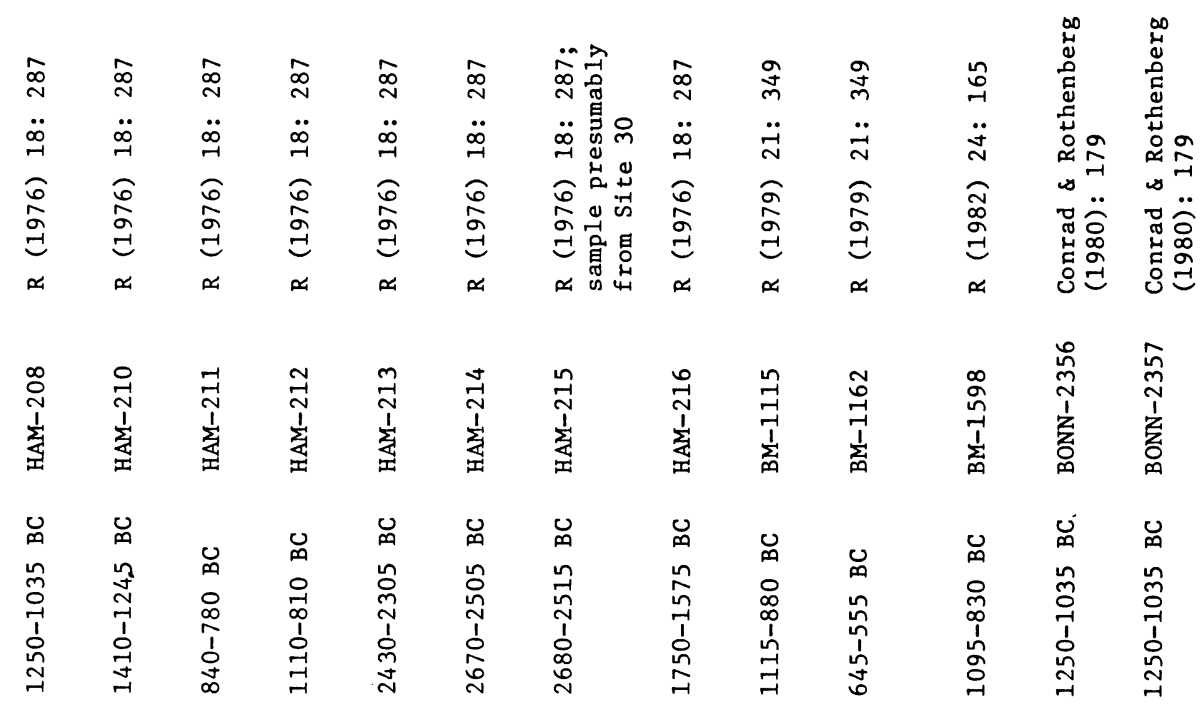

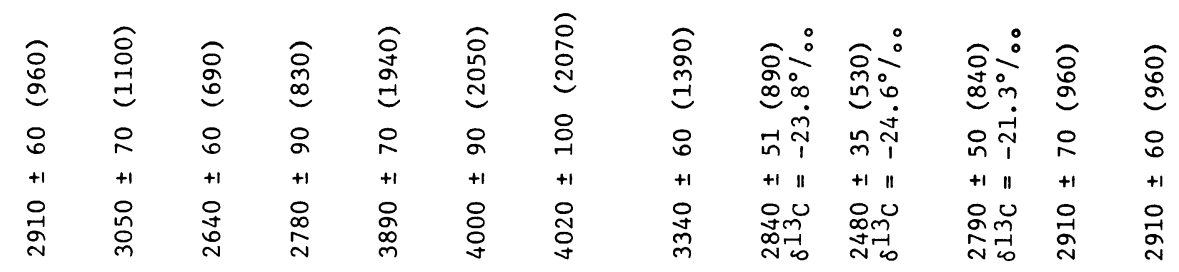

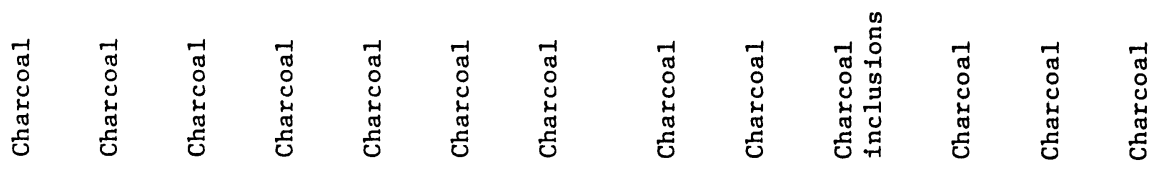

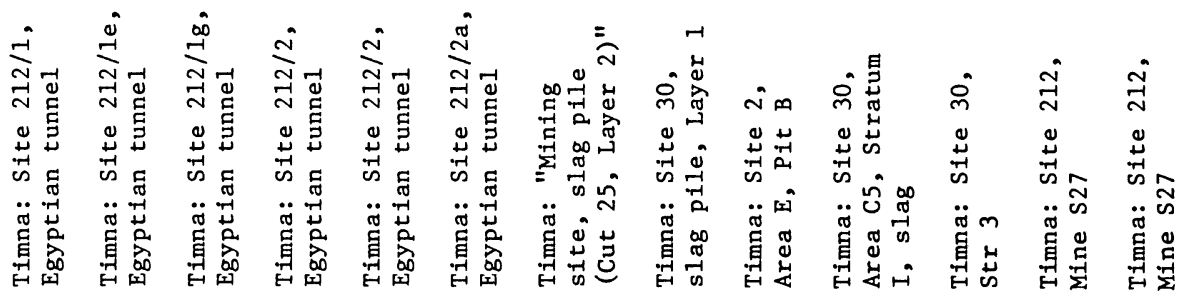




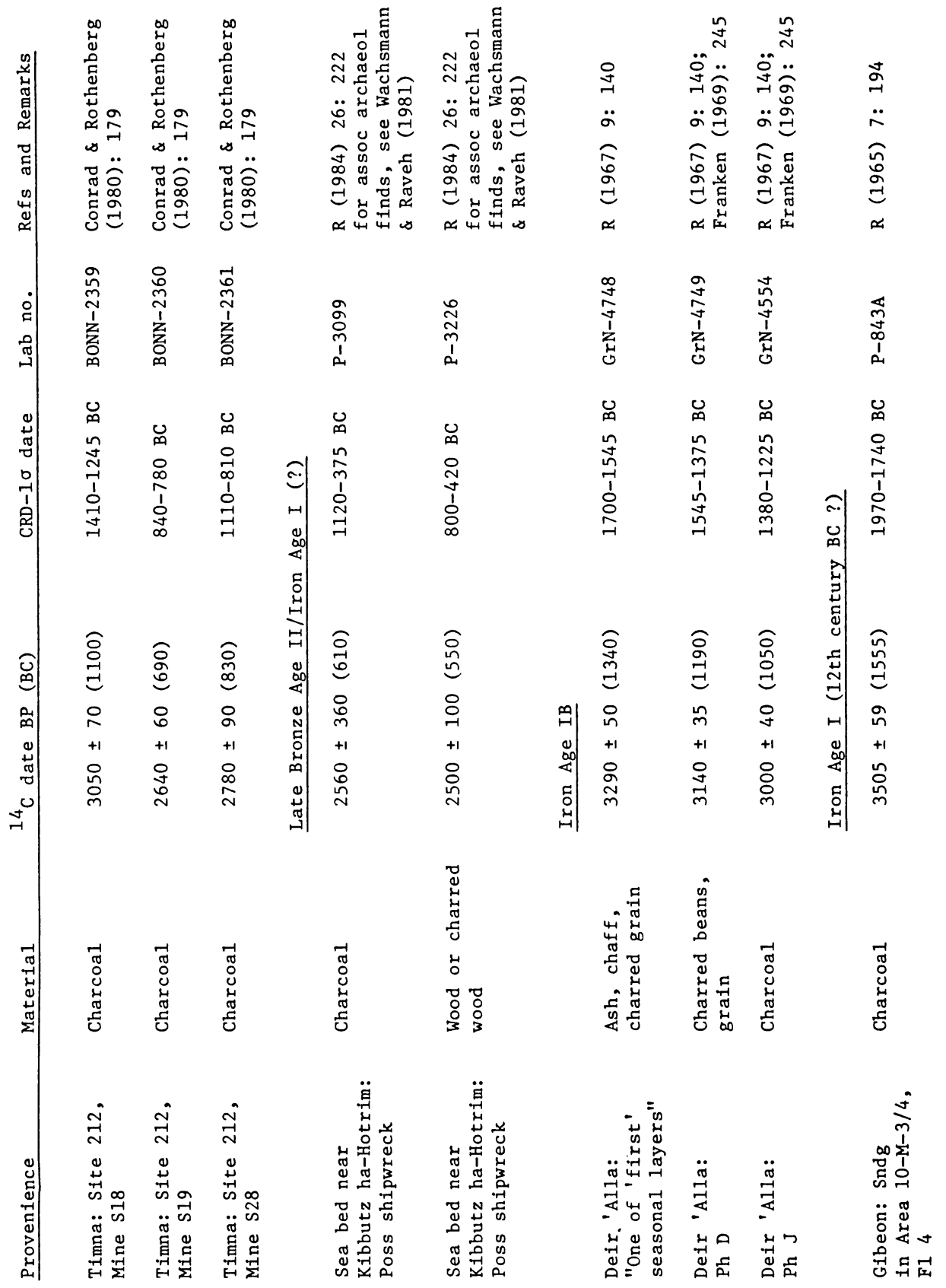




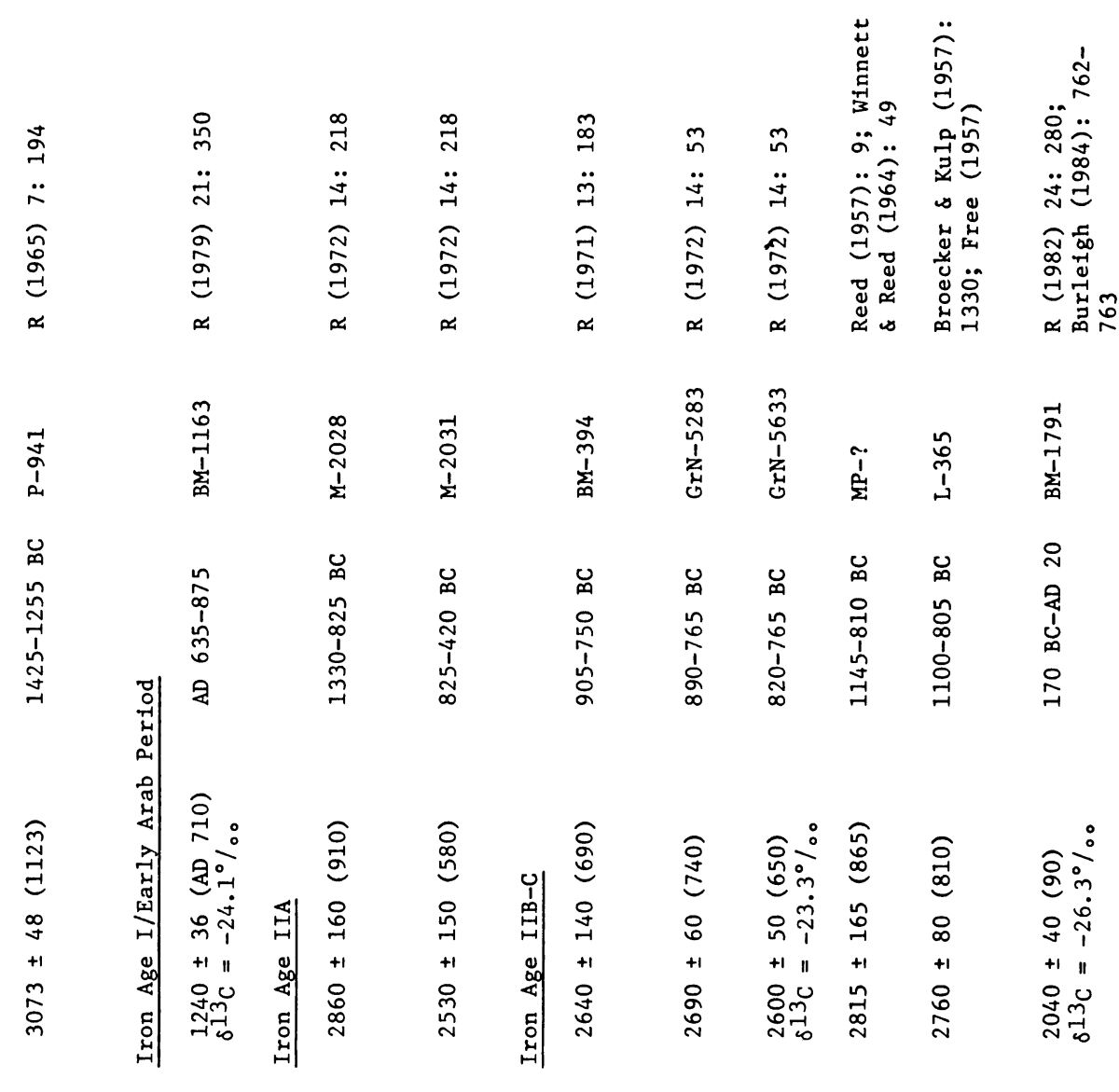

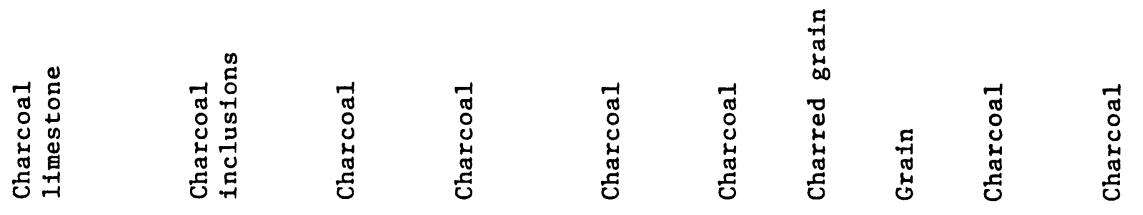

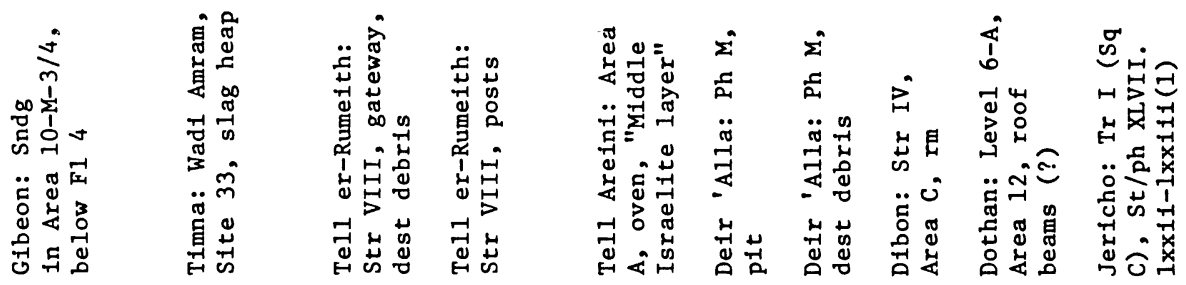




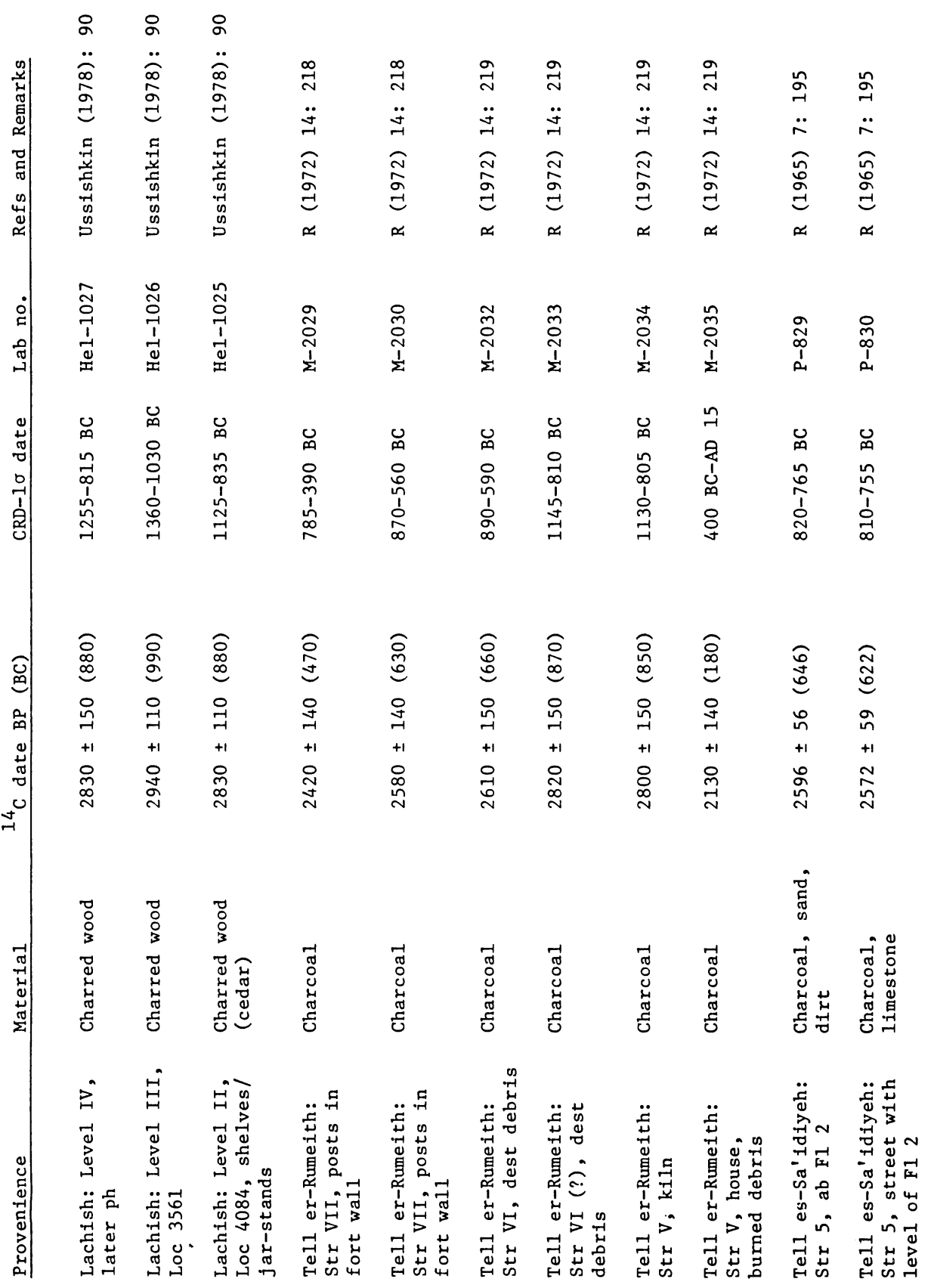




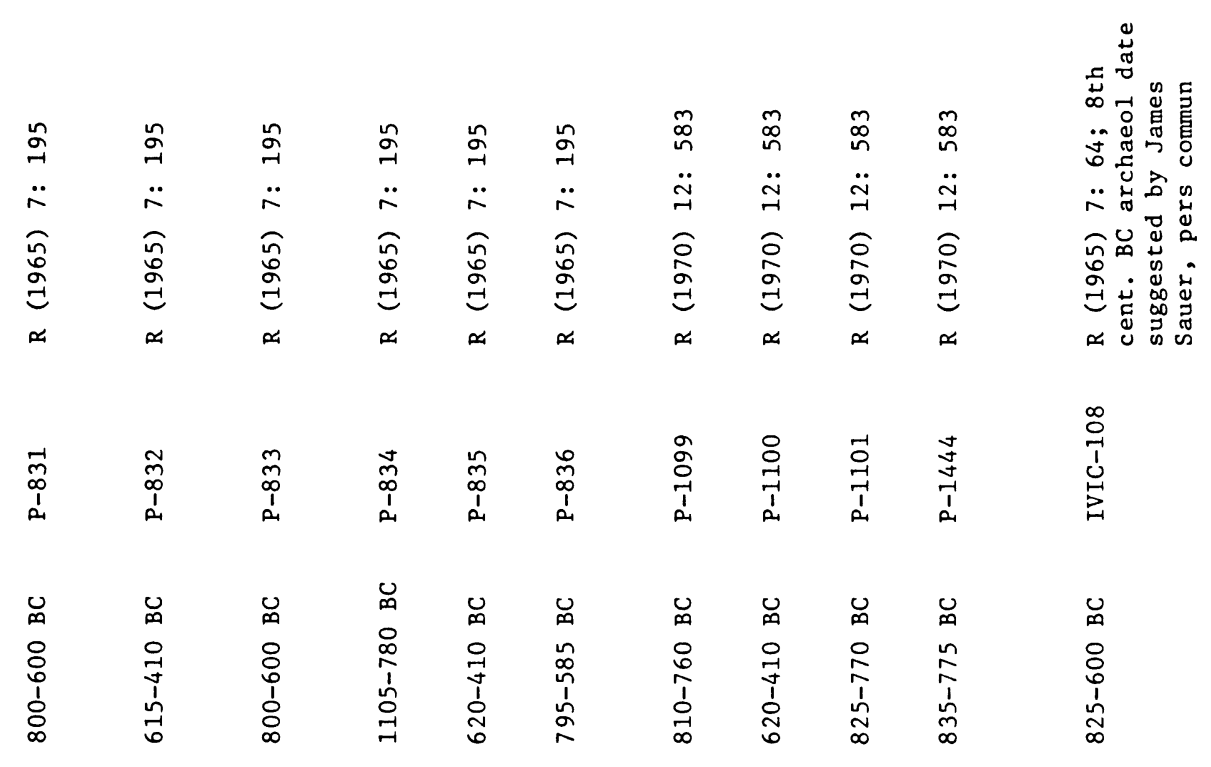

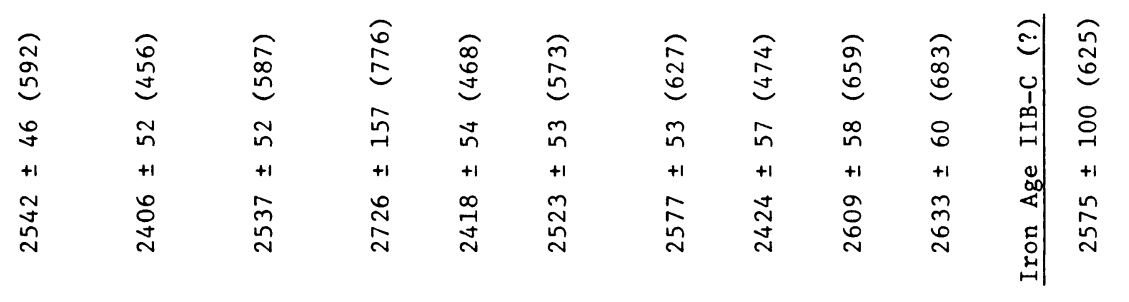

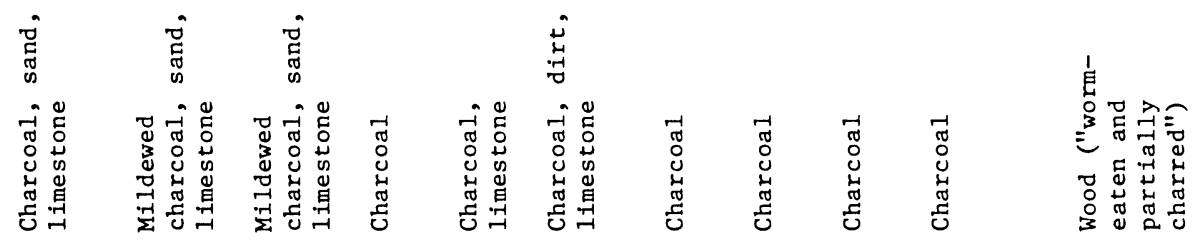

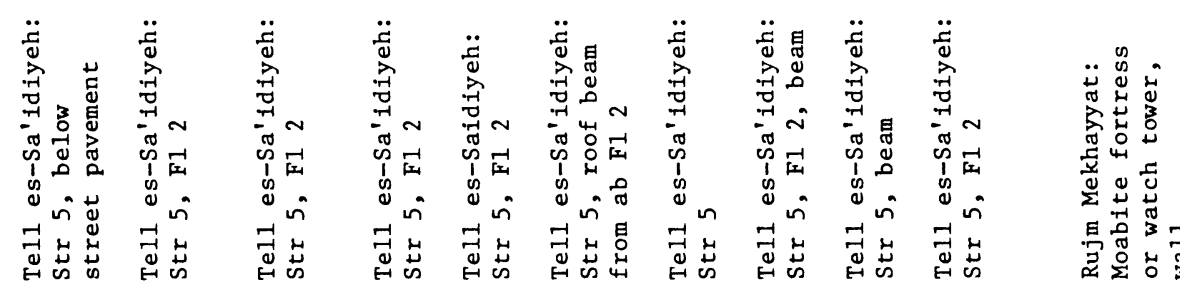




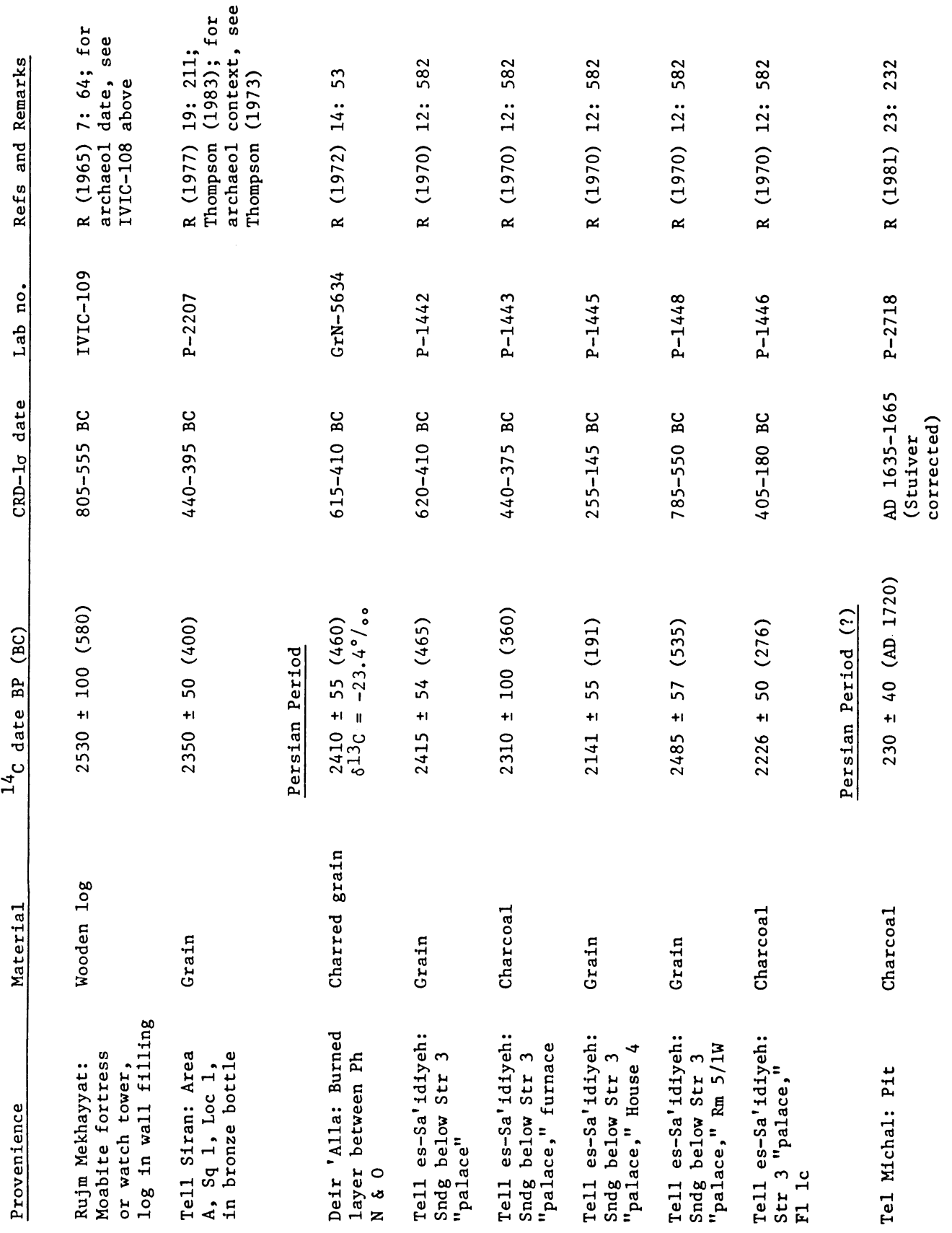




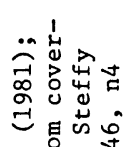

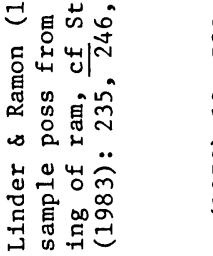

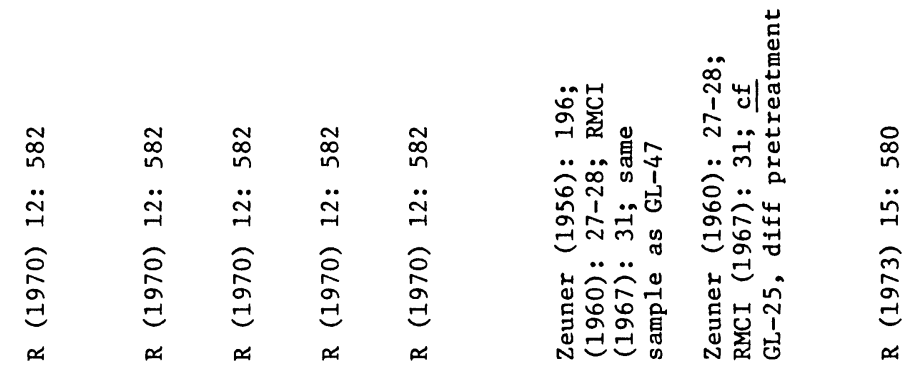

ì

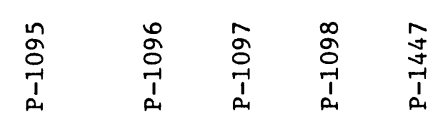

$\underset{\substack{1 \\ 1}}{\stackrel{f}{1}}$

f.

品

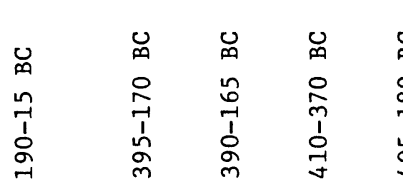

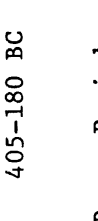

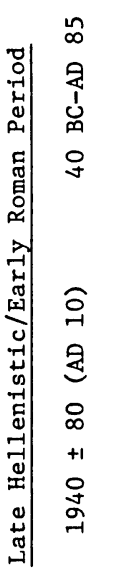

$\therefore$ in

竞 离

:



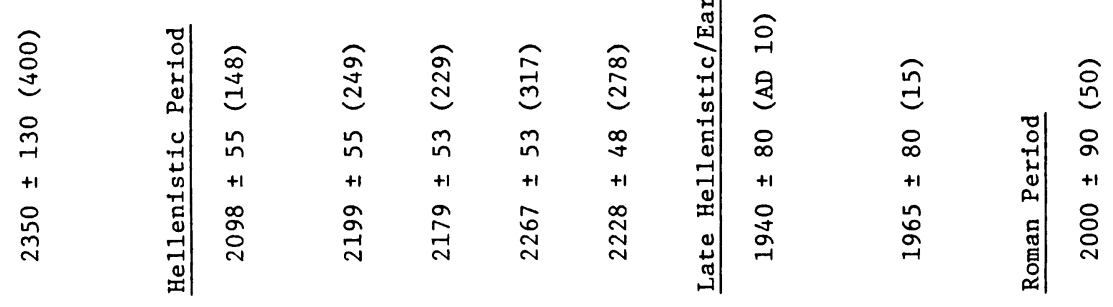

$\sum_{\overline{0}}^{\vec{D}}$

总要

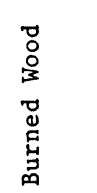

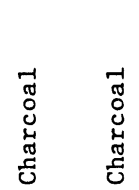

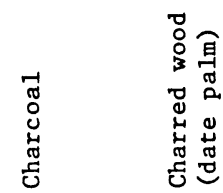

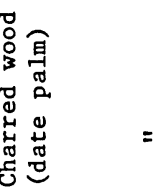

:

荡

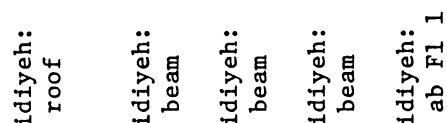

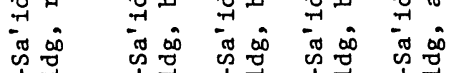

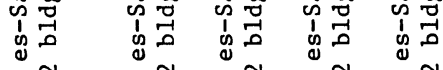

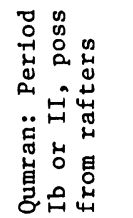

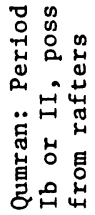

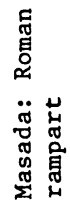




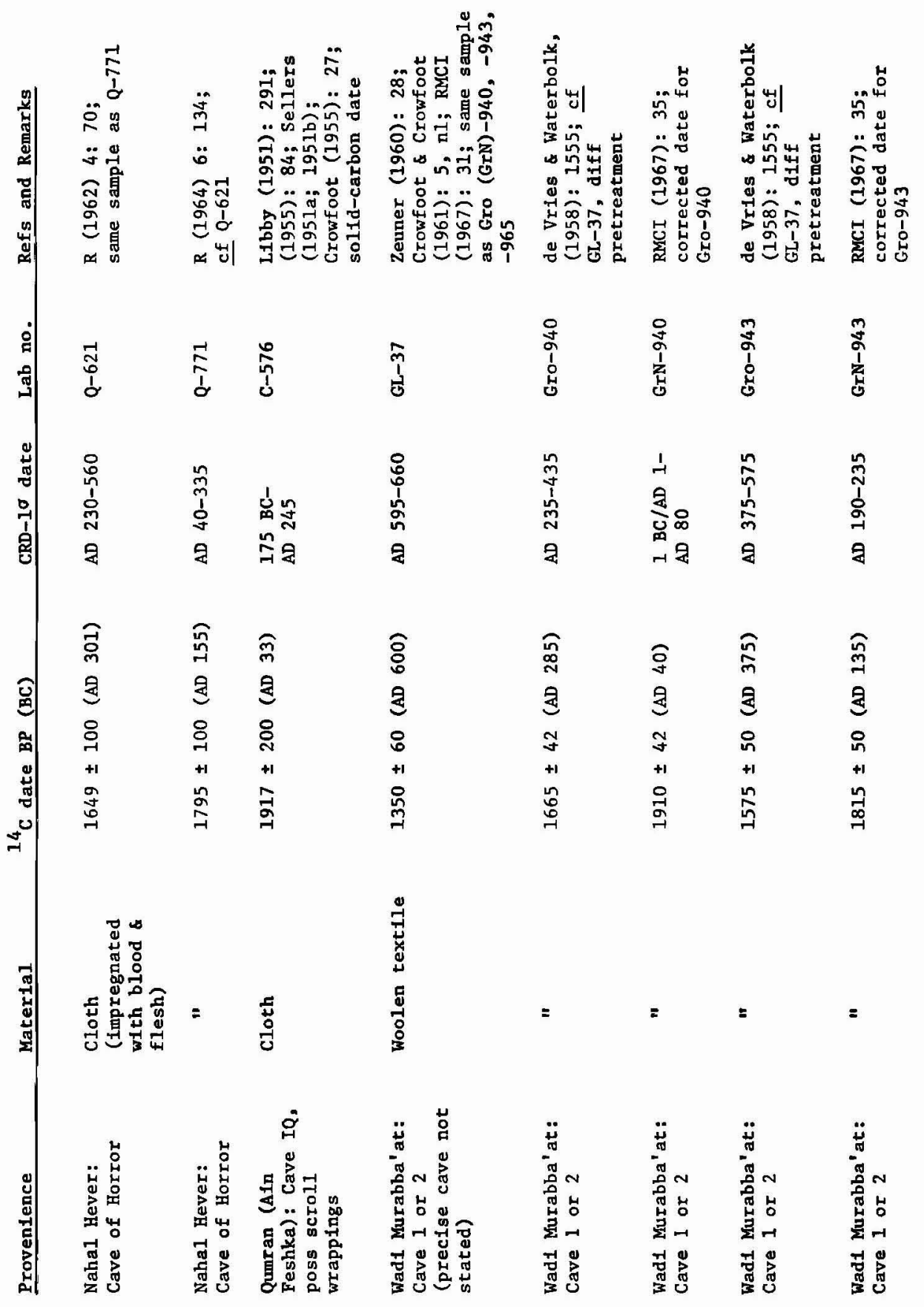



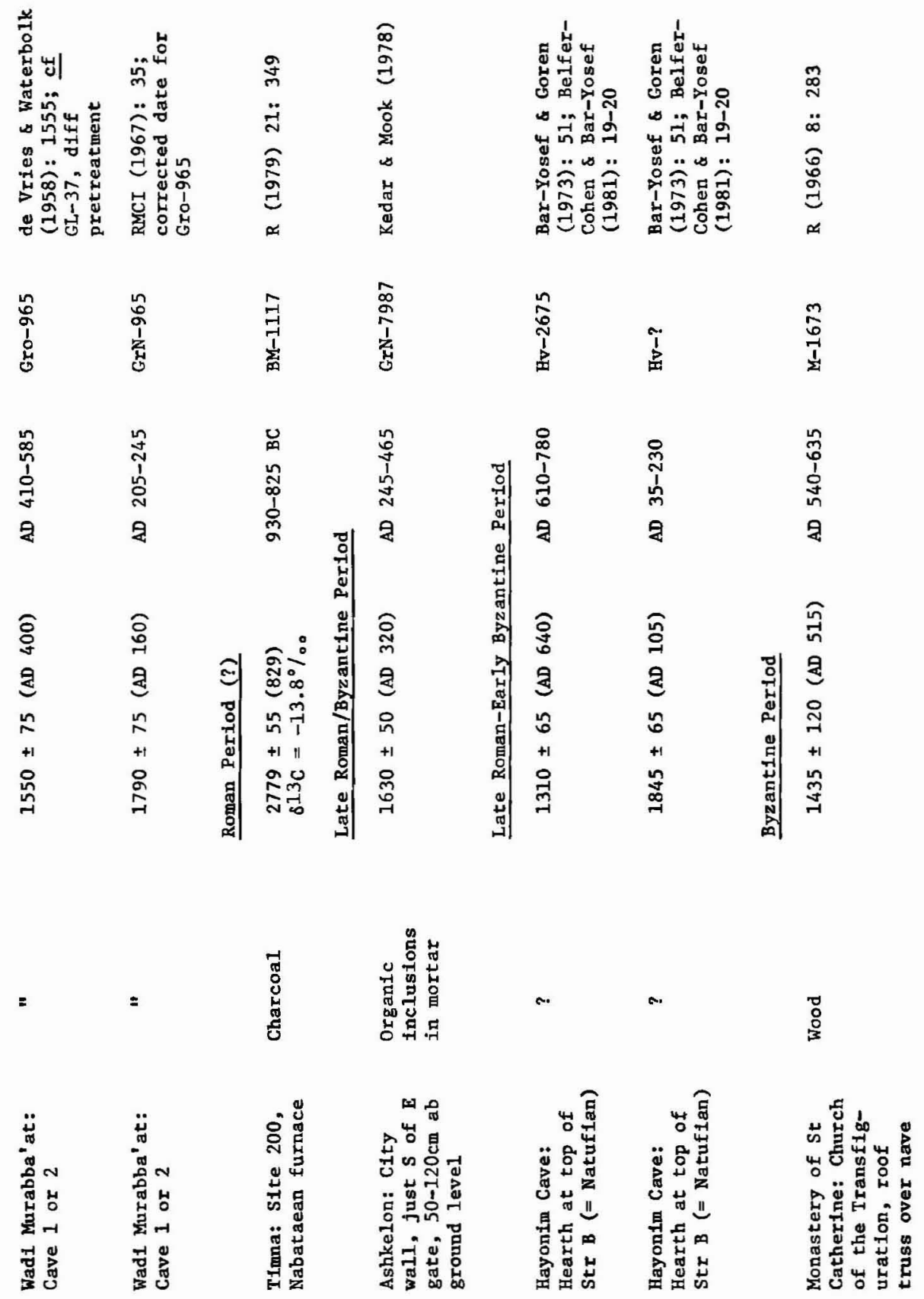


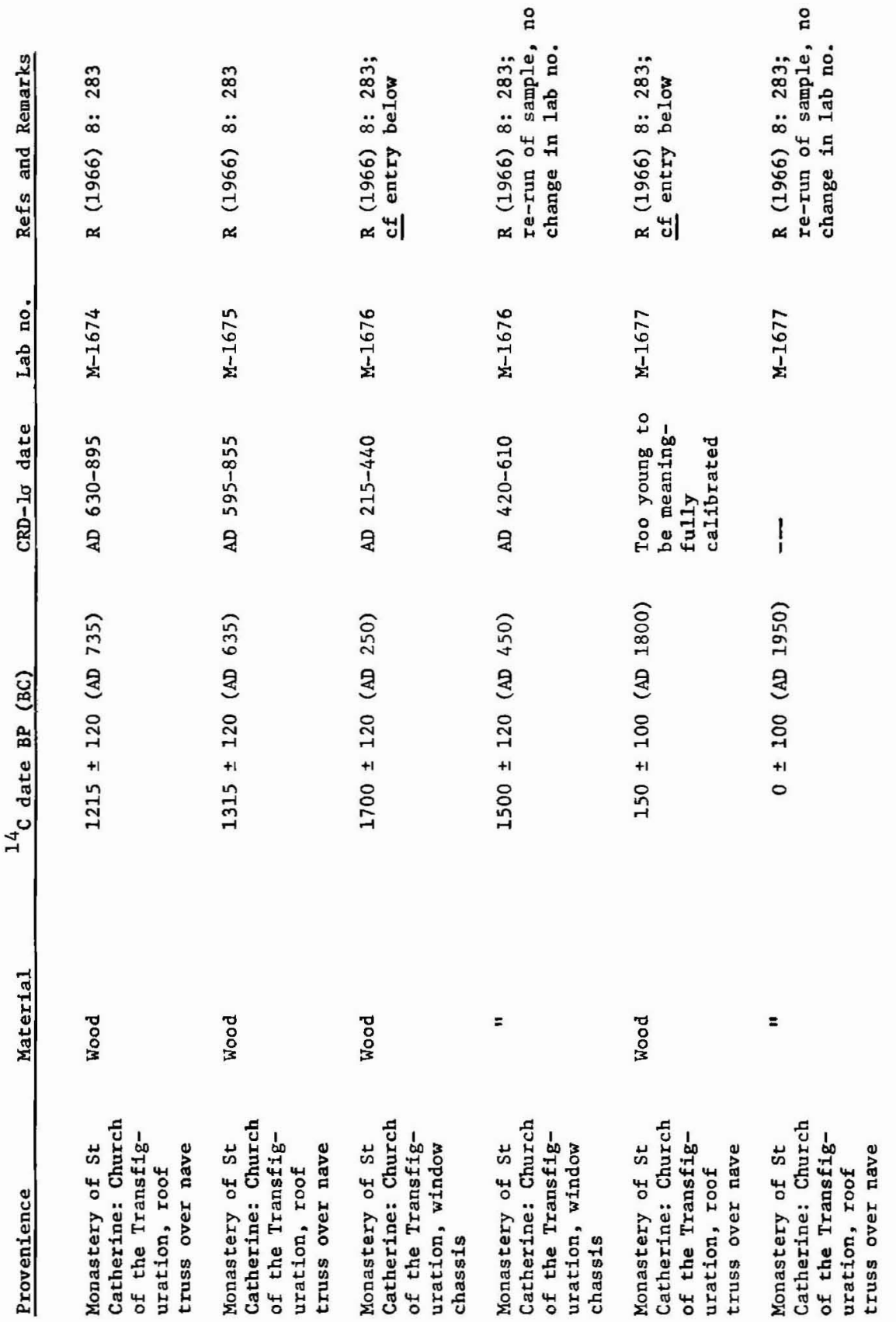




\begin{tabular}{|c|c|c|c|c|}
\hline 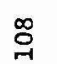 & 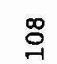 & $\underset{\sim}{\stackrel{్}{二}}$ & $\underset{\sim}{\mathbb{U}}$ & مِ \\
\hline$\ddot{g}$ & $\ddot{\Delta}$ & $\ddot{\theta}$ & $\ddot{z}$ & $\ddot{\Delta}$ \\
\hline $\begin{array}{l}\widehat{\infty} \\
\text { よे } \\
\text { ¿ }\end{array}$ & $\begin{array}{l}\widehat{\alpha} \\
\stackrel{\circ}{\Xi} \\
\text { dे }\end{array}$ & $\begin{array}{l}\infty \\
\stackrel{0}{\circ} \\
\stackrel{్}{=}\end{array}$ & $\begin{array}{l}\text { I } \\
\text { oू } \\
己\end{array}$ & 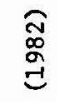 \\
\hline & $\alpha$ & $\alpha$ & $\propto$ & $\approx$ \\
\hline
\end{tabular}

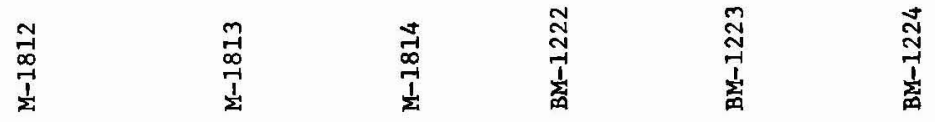

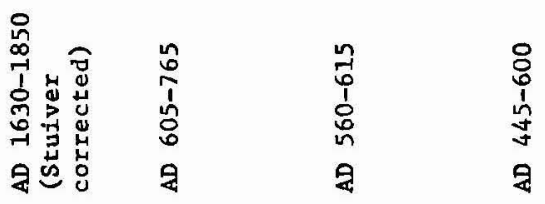

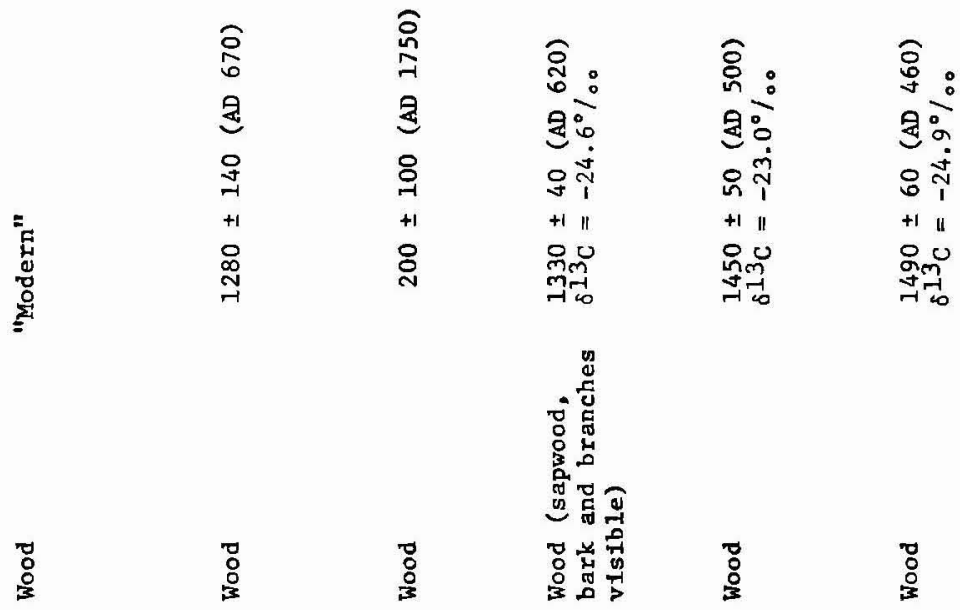

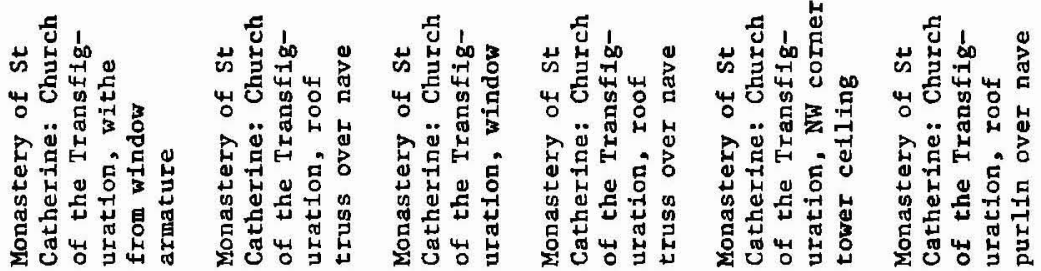




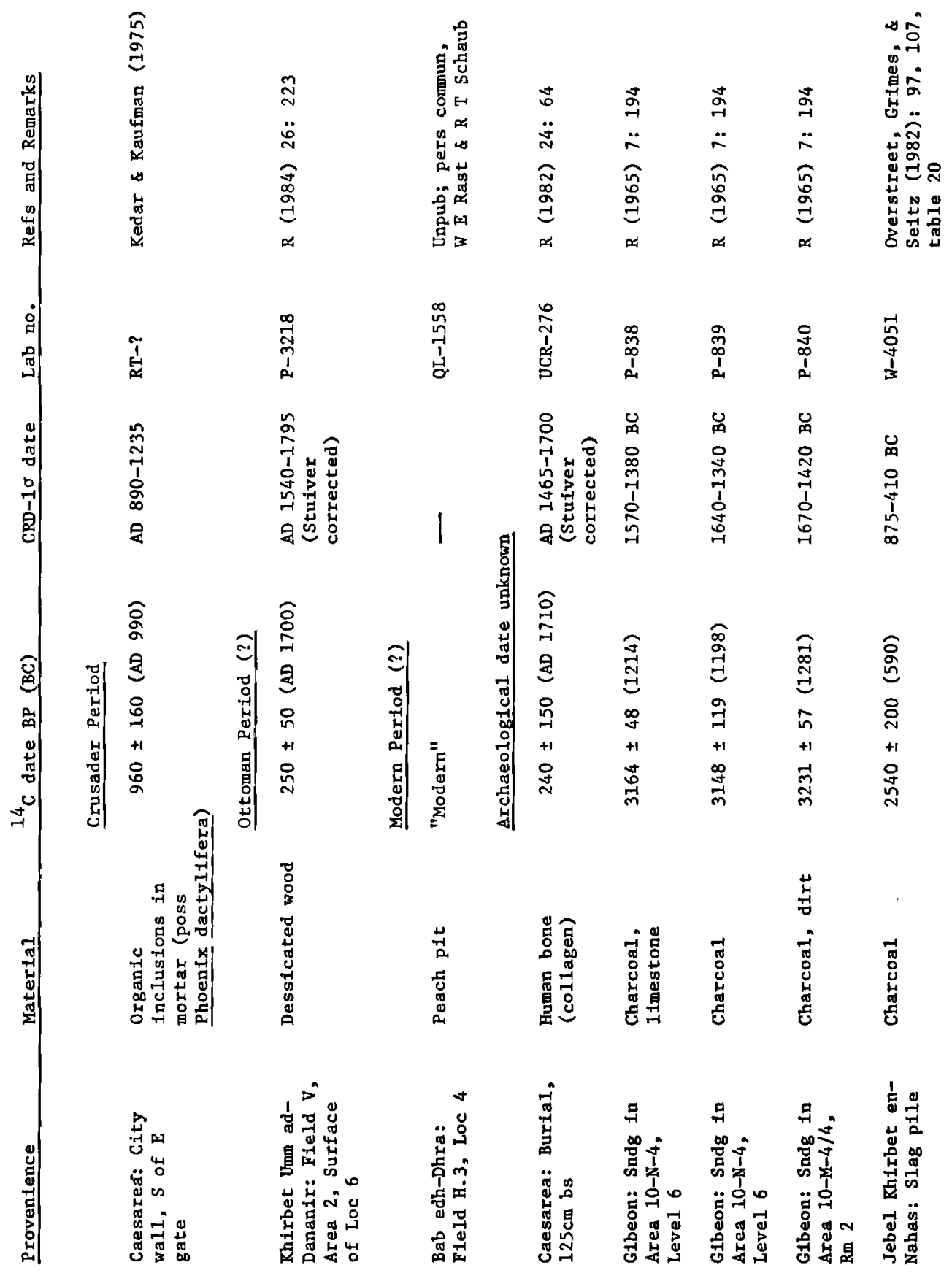




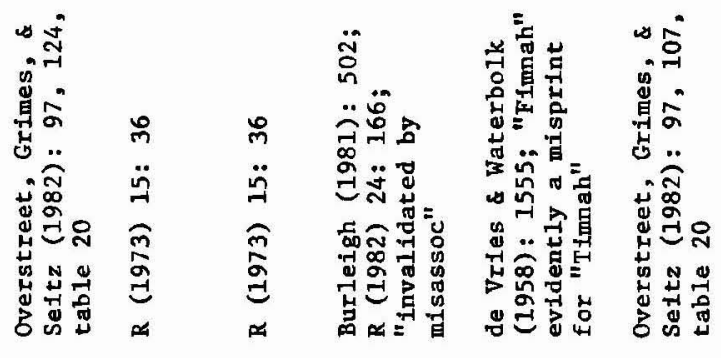

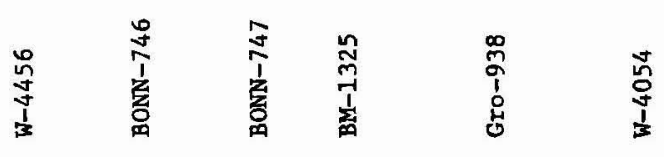

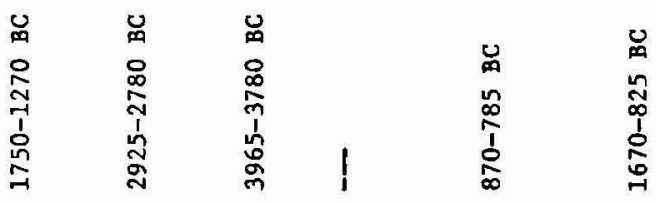

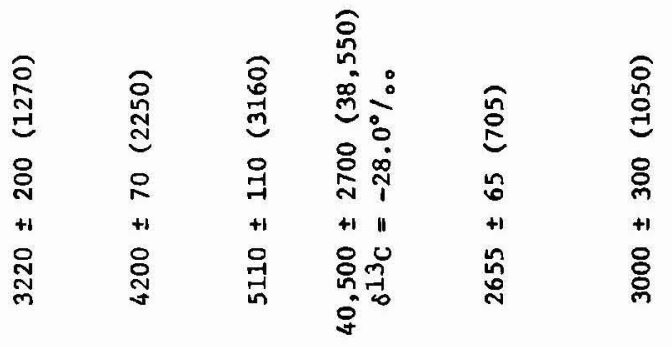

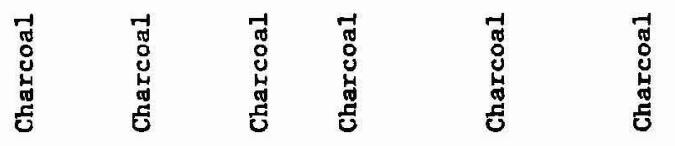

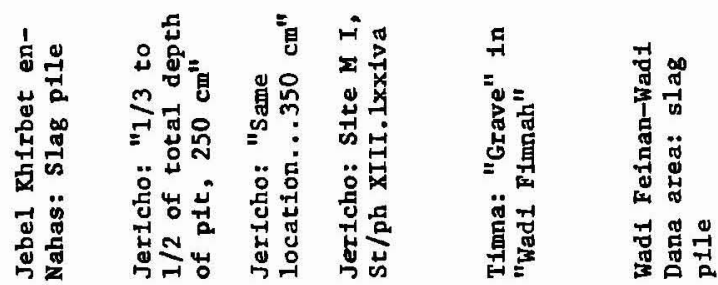




\section{REFERENCES}

Aharoni, Yohanan, 1962, Expedition B-The cave of horror: Israel Explor Jour, v 12, no. 3-4, p 186-199.

1964, The second season of excavation at Tel Arad (1963): Yediot, v 28, no. 3-4, p 153-175 (Hebrew).

1967, Excavations at Tel Arad: preliminary report on the second season, 1963: Israel Explor Jour, v 17, no. 4, p 233-249.

Amiran, Ruth, Paran, Uzzi, Shiloh, Yigal, Brown, Rafi, Tsafrir, Yoram, and Ben-Tor, Amnon, 1978, Early Arad: The Chalcolithic settlement and Early Bronze city, v I: First-fifth seasons of excavations, 1962-1966: Jerusalem, Israel Explor Soc, 130 p.

Bar-Adon, Pessah, 1980, The cave of the treasure: The finds from the caves in Nahal Mishmar: Jerusalem, Israel Explor Soc, 243 p.

Bar-Yosef, Ofer, 1975, The Epipalaeolithic in Palestine and Sinai, in Wendorf, Fred and Marks, A E, eds, Problems in prehistory: North Africa and the Levant: Dallas, Texas, Southern Methodist Univ Press, p 363-378.

1981a, The Epi-Palaeolithic complexes in the southern Levant, in Cauvin, Jacques and Sanlaville, Paul, eds, Préhistoire du Levant: Paris, Centre Nat Recherche Sci, p 389-408.

1981b, The $<<$ Pre-Pottery $>>$ Neolithic period in the southern Levant, in Cauvin, Jacques and Sanlaville, Paul, eds, Préhistoire du Levant: Paris, Centre Nat Recherche Sci, p 555-569.

Bar-Yosef, Ofer and Belfer, Anna, 1977, The Lagaman industry, in Bar-Yosef, Ofer and Phillips, J L, eds, Prehistoric investigations in Gebel Maghara, northern Sinai: Jerusalem, Inst Archaeol, Hebrew Univ Jerusalem, p 42-84.

Bar-Yosef, Ofer, Gopher, A, and Goring-Morris, A N, 1980, Netiv Hagdud: A 'Sultanian' mound in the lower Jordan valley: Paléorient, v 6, p 201-206.

Bar-Yosef, Ofer and Goren, Naama, 1973, Natufian remains in Hayonim cave: Paléorient, v l, p 49-68.

Bar-Yosef, Ofer and Goring-Morris, A N, 1977, Geometric Kebaran A occurrences, in Bar-Yosef, Ofer and Phillips, J L, eds, Prehistoric investigations in Gebel Maghara, northern Sinai: Jerusalem, Inst Archacol, Hebrew Univ Jerusalem, p 115-148.

Bar-Yosef, Ofer and Phillips, James L, 1977, Prehistoric investigations in Gebel Maghara, northern Sinai: Jerusalem, Inst Archaeol, Hebrew Univ Jerusalem, 269 p.

Belfer-Cohen, Anna and Bar-Yosef, Ofer, 1981, The Aurignacian at Hayonim cave: Paléorient, v 7, no. 2, p 19-42.

Belfer-Cohen, Anna and Goldberg, Paul, 1982, An Upper Palaeolithic site in south central Sinai: Israel Explor Jour, v 32, no. 4, p 185-189.

Blake, Ian, 1969, Climate, survival and the second-class societies in Palestine before 3000 BC: Advancement Sci, v 25, no. 126, p 409-421.

Broecker, W S and Kulp, J L, 1957, Lamont natural radiocarbon measurements IV: Science, $v$ 126, no. 3287, p 1324-1334.

Burleigh, Richard, 1981, Radiocarbon dates, in Kenyon, K M, Excavations at Jericho, v 3: The architecture and stratigraphy of the tell, Holland, T A, ed: London, British School Archaeol Jerusalem, p 501-504.

1984, Additional radiocarbon dates for Jericho (with an assessment of all the dates obtained), in Kenyon, $\mathrm{K} \mathrm{M}$ and Holland, $\mathrm{T}$ A, Excavations at Jericho, v 5: The pottery phases of the tell and other finds: London, British School Archaeol Jerusalem, $\mathrm{p}$ 760-765.

Callaway, J A, 1972, The Early Bronze age sanctuary at Ai (et-Tell), no. 1: London, Bernard Quaritch Ltd, $341 \mathrm{p}$.

Callaway, J A and Weinstein, J M, 1977, Radiocarbon dating of Palestine in the Early Bronze age: Am Schools Oriental Research Bull, no. 225, p 1-16.

Chinzei, Kiyotaka, 1970, The Amud cave site and its deposit, in Suzuki, Hisashi and Takai, Fuyuji, eds, The Amud man and his cave site: Tokyo, Univ Tokyo Press, p $21-52$.

Conrad, H G and Rothenberg, Benno, eds, 1980, Antikes Kupfer im Timna-Tal: 4000 Jahre Bergbau und Verhüttung in der Arabah (Israel): Bochum, Deutsches Berg-
bau-Mus, $236 \mathrm{p}$.

Copeland, Lorraine and Vita-Finzi, Claudio, 1978, Archaeological dating of geological deposits in Jordan: Levant, v 10, p 10-25.

Crew, H L, 1976, The Mousterian site of Rosh Ein Mor, in Marks, A E, ed, Prehistory and paleoenvironments in the central Negev, Israel, v I, The Avdat/Aqev area, pt 1: Dallas, Texas, Southern Methodist Univ Press, p 75-112.

Crowfoot, G M, 1955, The linen textiles, in Barthélemy, Dominique and Milik, J T, Discoveries in the Judaean desert, v I: Qumran Cave I: Oxford: Clarendon Press,
p 18-38. 
Crowfoot, G M and Crowfoot, Elizabeth, 1961, The textiles and basketry, in Benoit, P, Milik, J T, and Vaux, Roland de, Discoveries in the Judaean desert, v II: Les grottes de Murabba 'ât: Oxford: Clarendon Press, p 51-63.

Deevey, E S, Flint, R F, and Rouse, Irving, eds, 1967, Radiocarbon measurements: comprehensive index, 1950-1965: Am Jour Sci, $221 \mathrm{p}$.

Dever, W G, 1973, The EB IV-MB I horizon in Transjordan and southern Palestine: Am Schools Oriental Research Bull no. 210, p 37-63.

1982, Review of Amiran, Ruth, Paran, Uzzi, Shiloh, Yigal, Brown, Rafi, Tsafrir, Yoram, and Ben-Tor, Amnon, Early Arad: The Chalcolithic settlement and Early Bronze city, v I: Israel Explor Jour, v 32, no. 2-3, p 170-175.

Dever, W G, Lance, H D, Bullard, R G, Cole, D P, and Seger, J D, 1974, Gezer II: Report of the 1967-70 seasons in Fields I and II. Jerusalem: Hebrew Union Coll/ Nelson Glueck School Biblical Archaeol, $137 \mathrm{p}$.

Dothan, Moshe, 1956, Radioactive examination of archacological material from Israel: Israel Explor Jour, v 6, no. 2, p 112-114.

Epstein, Claire, 1979, Golan, Chalcolithic sites, 1978: Israel Explor Jour, v 29, no. 3-4, p 225-227. p $112-116$.

Franken, H J, 1969, Excavations at Tell Deir ${ }^{\mathrm{c} A l l a ~ I: ~ A ~ s t r a t i g r a p h i c a l ~ a n d ~ a n a l y t i c a l ~}$ study of the Early Iron age pottery: Leiden, E J Brill, $249 \mathrm{p}$.

Free, J P, 1957, Radiocarbon date of Iron age level at Dothan: Am Schools Oriental Research Bull, no. 147, p 36-37.

Gisis, I and Gilead, Isaac, 1977, Lagama III, in Bar-Yosef, Ofer and Phillips, J L, eds, Prehistoric investigations in Gebel Maghara, northern Sinai: Jerusalem, Inst Archaeol, Hebrew Univ Jerusalem, p 85-102.

Gophna, Ram, 1979, Tell Tsaf-a Chalcolithic settlement on the banks of the Jordan: Qadmoniot, v 12, no. 2-3, p 54-56 (Hebrew).

Gophna, Ram and Kislev, M, 1979, Tel Șaf (1977-1978): Rev Biblique, v 86, no. 1, p 112 114 .

Goring-Morris, A N and Gopher, A, 1983, Nahal Issaron: A Neolithic settlement in the southern Negev: Israel Explor Jour, v 33, no. 3-4, p 149-162.

Haas, Herbert, 1977, Radiocarbon dating of charcoal and ostrich egg shells from $\mathrm{Mu}$ shabi and Lagama sites, in Bar-Yosef, Ofer and Phillips, J L, eds, Prehistoric investigations in Gebel Maghara, northern Sinai: Jerusalem, Inst Archaeol, Hebrew Univ Jerusalem, p 261-264.

Hamada, Tatsuji, 1970, Comments on the reliability of bone radiocarbon, in Suzuki, Hisashi and Takai, Fuyuji, eds, The Amud man and his cave site: Tokyo, Univ Tokyo Press, p 423-424.

Helback, Hans, 1974, Grain from the Tell Siran bronze bottle: Dept Antiquities Jordan Ann, v 19, p 167-168.

Hennessy, J B, 1982, Teleilat Ghassul: Its place in the archaeology of Jordan, in Hadidi, Adnan, ed, Studies in the history and archaeology of Jordan I: Amman, Dept Antiquities, p 55-58.

Henry, D O, 1982, The prehistory of southern Jordan and relationships with the Levant: Jour Field Archaeol, v 9, no. 4, p 417-444.

1983, Adaptive evolution within the Epipalcolithic of the Near East, in Wendorf, Fred and Close, A E, eds, Advances in World Archacol, v 2, p 99-160.

Henry, D O, Hassan, F A, Cooper Henry, Kathleen, and Jones, Marcia, 1983, An investigation of the prehistory of southern Jordan: Palestine Explor Quarterly, v 115, p 1-24.

Henry, D O and Leroi-Gourhan, Arlette, 1976, The excavation of Hayonim terrace: An interim report: Jour Field Archacol, v 3, no. 4, p 391-406.

Henry, D O and Servello, A F, 1974, Compendium of carbon-14 determinations derived from Near Eastern prehistoric deposits: Palćorient, v 2, no. 1, p 19-44.

Hietala, Harold and Marks, A E, 1981, Changes in spatial organization at the Middle to Upper Palaeolithic site of Boker Tachtit, central Negev, Israel, in Cauvin, Jacques and Sanlaville, Paul, eds, Préhistoire du Levant: Paris, Centre Nat Recherche Sci, p $305-318$.

Jelinek, A J, 1982, The Tabun cave and Paleolithic man in the Levant: Science, v 216, no. 4553, p 1369-1375.

Kaplan, Jacob, 1969, 'Ein el Jarba: Chalcolithic remains in the plain of Esdraelon: Am Schools Oriental Research Bull, no. 194, p 2-39.

Kaufman, Daniel, 1983, D101 B: A Mushabian site in the Nahal Zin, in Marks, A E, ed, Prehistory and paleoenvironments in the central Negev, Israel, v III, The Avdat/ 
Aqev area, pt 3: Dallas, Texas, Dept Anthropol, Southern Methodist Univ, p 333341

Kedar, B Z and Kaufman, A, 1975, Radiocarbon measurements of medieval mortars: A preliminary report: Israel Explor Jour, v 25, no. 1, p 36-38.

Kedar, B Z and Mook, W G, 1978, Radiocarbon dating of mortar from the city-wall of Ascalon: Israel Explor Jour, v 28, no. 3, p 173-176.

Kenyon, K M, 1959, Earliest Jericho: Antiquity, v 33, no. 129, p 5-9.

Co, $360 \mathrm{p}$

Klein, Jeffrey, Lerman, J C, Damon, P E, and Ralph, E K, 1982, Calibration of radiocarbon dates: Tables based on the consensus data of the Workshop on Calibrating the Radiocarbon Time Scale: Radiocarbon, v 24, no. 2, p 103-150.

Lapp, P W, 1963, Tell er-Rumeith: Rev Biblique, v 70, no. 3, p 406-411. 1968, Tell er-Rumeith: Rev Biblique, v 75, no. 1, p 98-105.

Lee, J R, (ms), 1973, Chalcolithic Ghassul: New aspects and master typology: PhD dissert, Hebrew Univ Jerusalem.

Levy, T E, (ms), 1981, Chalcolithic settlement and subsistence in the northern Negev desert, Israel: PhD dissert, Sheffield Univ, England.

Libby, W F, 1951, Radiocarbon dates, II: Science, v 114, no. 2960, p 291-296.

1954, Chicago radiocarbon dates V: Science, v 120, no. 3123, p 733-742.

1955, Radiocarbon dating, 2nd ed: Chicago, Univ Chicago Press, $175 \mathrm{p}$

Linder, Elisha and Ramon, Yehoshua, 1981, A bronze ram from the Sea of Athlit, Israel: Archaeology, v 34, no. 6, p 62-64.

Marks, A E, 1975, An outline of prehistoric occurrences and chronology in the central Negev, Israel, in Wendorf, Fred and Marks, A E, eds, Problems in prehistory: North Africa and the Levant: Dallas, Texas, Southern Methodist Univ Press, p 351-362.

_- 1976a, Ein Aqev: A Late Levantine Upper Paleolithic site in the Nahal Aqev, with an appendix by J Anne Attebury, in Marks, A E, ed, Prehistory and paleoenvironments in the central Negev, Israel, v I, The Avdat/Aqev area, pt 1: Dallas, Texas, Southern Methodist Univ Press, p 227-291.

1976b, Site D5: A Geometric Kebaran "A" occupation in the Nahal Zin, in Marks, A E, ed, Prehistory and paleoenvironments in the central Negev, Israel, v I, The Avdat/Aqev area, pt 1: Dallas, Texas, Southern Methodist Univ Press, p 293-
316.

1977a, Introduction: A preliminary overview of central Negev prehistory, in Marks, A E, ed, Prehistory and paleoenvironments in the central Negev, Israel, v II The Avdat/Aqev area, pt 2 and the Har Harif: Dallas, Texas, Dept Anthropol, Southern Methodist Univ, p 3-34.

1977b, The Upper Paleolithic sites of Boker Tachtit and Boker: A preliminary report, in Marks, A E, ed, Prehistory and paleoenvironments in the central Negev, Israel, v II, The Avdat/Aqev area, pt 2 and the Har Harif: Dallas, Texas, Dept Anthropol, Southern Methodist Univ, p 61-79. 1981a, The Middle Paleolithic of the Negev, Israel, in Cauvin, Jacques and Sanlaville, Paul, eds, Préhistoire du Levant: Paris, Centre Nat Recherche Sci, p 287-
298.

ville $1981 \mathrm{~b}$, The Upper Paleolithic of the Negev, in Cauvin, Jacques and Sanlaville, Paul, eds, Préhistoire du Levant: Paris, Centre Nat Recherche Sci, p 343-352.

Marks, A E and Larson, P A, Jr, 1977, Test excavations at the Natufian site of Rosh Horesha, in Marks, A E, ed, Prehistory and paleoenvironments in the central Negev, Israel, v II, The Avdat/Aqev area, pt 2 and the Har Harif: Dallas, Texas, Dept Anthropol, Southern Methodist Univ, p 191-232

Marks, A E and Scott, T R, 1976, Abu Salem: Type site of the Harifian industry of the southern Levant: Jour Field Archaeol, v 3, no. 1, p 43-60.

Mellaart, James, 1979, Egyptian and Near Eastern chronology: a dilemma?: Antiquity, v 53, no. 207, p 6-18

Mendenhall, G E, 1971, The "Philistine" documents from the Hebron area: A supplementary note: Dept Antiquities Jordan Ann, v 16, p 99-102.

Moore, A M T, 1982, A four-stage sequence for the Levantine Neolithic, ca 8500-3750 BC: Am Schools Oriental Research Bull, no. 246, p 1-34.

Naveh, Joseph, 1982, Some recently forged inscriptions: Am Schools Oriental Research Bull, no. 247, p 53-58.

Noy, Tamar, Legge, A J, and Higgs, E S, 1973, Recent excavations at Nahal Oren, Israel Prehist Soc Proc, v 39, p 75-99.

Overstreet, W C, Grimes, D J, and Seitz, J F, 1982, Gcochemical orientation for mineral exploration in the Hashemite Kingdom of Jordan: U S Geol Survey open-file rept 82-0791, $225 \mathrm{p}$. 
Perrot, Jean, 1968, Préhistoire Palestinienne, in Dictionnaire de la Bible, supplément 8: Paris, Letouzey \& Ané, cols 286-446.

Phillips, J L and Mintz, E, 1977, The Mushabian, in Bar-Yosef, Ofer and Phillips, J L, eds, Prehistoric investigations in Gebel Maghara, northern Sinai: Jerusalem, Inst Archaeol, Hebrew Univ Jerusalem, p 149-183.

Prausnitz, M W and Wreschner, Ernst, 1971, Neve-Yam-A submerged Neolithic settlement: Qadmoniot, v 4, no. 4, p 120-121 (Hebrew).

Pritchard, J B, 1964, Winery, defenses, and soundings at Gibeon: Philadelphia, Univ Mus, Univ Pennsylvania, 130 p.

Rast, W E, 1981, Settlement at Numeira, in Rast, W E and Schaub, R T, eds, The southeastern Dead Sea plain expedition: An interim report of the 1977 season: Am Schools Oriental Research Ann, v 46, p 35-44.

Rast, W E and Schaub, R T, 1978, A preliminary report of excavations at Bâb edhDhrâ ${ }^{c}, 1975$ : Am Schools Oriental Research Ann, v 43, p 1-32.

1980, Preliminary report of the 1979 expedition to the Dead Sea plain, Jordan: Am Schools Oriental Research Bull, no. 240, p 21-61.

Reed, W L, 1957, A recent analysis of grain from ancient Dibon in Moab: Am Schools Oriental Research Bull, no. 146, p 6-10.

Ronen, Avraham, 1973, New radiocarbon dates from Mt Carmel: Archaeology, v 26, no. $1, \mathrm{p}$ 60-62.

Rothenberg, Beno and Lupu, Alexander, 1967, Excavations at Timna: Preliminary report on the excavations at camp no. 2 in Wadi Timna, 1964-1966: Mus Haaretz Bull, v 9, p 53-70.

Rubin, Meyer and Suess, H E, 1956, U S Geological Survey radiocarbon dates III: Science, $v 123$, no. $3194, \mathrm{p} 442-448$.

schick, Tamar and Stekelis, Moshé, 1977, Mousterian assemblages in Kebara cave, Mount Carmel: Eretz-Israel, v 13, p 97*-149*.

Schwarcz, H P, Blackwell, Bonnie, Goldberg, Paul, and Marks, A E, 1979, Uranium series dating of travertine from archaeological sites, Nahal Zin, Israel: Nature, v 277, no. 5697 , p $558-560$.

Schwarcz, H P, Goldberg, P D, and Blackwell, Bonnie, 1980, Uranium series dating of archaeological sites in Israel: Israel Jour Earth-Sciences, v 29, no. 1-2, p 157-165.

Scott, T R, 1977, The Harifian of the Central Negev, in Marks, A E, ed, Prehistory and paleoenvironments in the central Negev, Israel, v II, The Avdat/Aqev area, pt 2 and the Har Harif: Dallas, Texas, Dept Anthropol, Southern Methodist Univ, p $271-322$.

Seger, J D, 1972, Shechem field XIII, 1969: Am Schools Oriental Research Bull, no. 205, p 20-35.

Sellers, O R, 1951a, Date of cloth from the "Ain Fashka cave: The Biblical Archacologist, $\mathrm{v} 14$, no. $1, \mathrm{p} 29$.

1951b, Radiocarbon dating of cloth from the ${ }^{\mathrm{C}}$ Ain Feshka cave: Am Schools Oricntal Research Bull, no. 123, p 24-26.

Servello, A F, 1976, Nahal Divshon: A Pre-Pottery Neolithic B hunting camp, in Marks, A E, ed, Prchistory and palcoenvironments in the central Negev, Israel, $v$ I, The Avdat/Aqev area, pt 1: Dallas, Texas, Southern Methodist Univ Press, p 349-370.

Steffy, J R, 1983, The Athlit ram: A preliminary investigation of its structure: The Mariner's Mirror, v 69, no. 3, p 227-247.

Stuiver, Minze, 1982, A high-precision calibration of the $\mathrm{AD}$ radiocarbon time scale: Radiocarbon, v 24, p 1-26.

Tchernov, E and Bar-Yosef, Ofer, 1982, Animal exploitation in the Pre-Pottery Neolithic B period at Wadi Tbeik, southern Sinai: Paléorient, v 8, no. 2, p 17-37.

Thompson, H O, 1973, The excavations of Tell Siran (1972): Dept Antiquities Jordan Ann, v 18, p 5-14.

1983, The Tell Siran bottle: An additional note: Am Schools Oriental Research Bull, no. 249, p 87-89.

Ussishkin, David, 1978, Excavations at Tel Lachish-1973-1977, preliminary report: Tel Aviv, v 5, no. 1-2, p 1-97. 1983, Excavations at Tel Lachish 1978-1983: Second preliminary report: Tel Aviv, v 10, no. 2, p $97-175$.

Vita-Finzi, Claudio, 1966, The Hasa formation: An alluvial deposition in Jordan: Man (NS), v 1, no. 3, p $386-390$.

Vries, Hessel de and Waterbolk, H T, 1958, Groningen radiocarbon dates III: Science, v 128 , no. 3338 , p 1550-1556.

Wachsmann, S and Raveh, K, 1981, An underwater salvage excavation near Kibbutz haHotrim, Israel: Internatl Jour Nautical Archacol Underwater Exploration, v 10, no. 2, p 160. 
Waterbolk, H T, 1971, Working with radiocarbon dates: Prehist Soc Proc, v 37, p 2, p 15-33.

Winnett, F V and Reed, W L, 1964, The excavations at Dibon (Dhībân) in Moab, pt 1-2: Am Schools Oriental Research Ann, v 36-37. New Haven, Am Schools Oriental Research, $79 \mathrm{p}$.

Wreschner, E E, 1967, The Geula caves--Mount Carmel. Excavation, finds and summary: Quaternaria, v 9, p 69-89.

1977, Newe Yam-A submerged Late-Neolithic settlement near Mount Carmel: Eretz-Israel, v 13, p $260 *-271 *$.

Yeivin, Ephrat and Olami, Yaakov, 1979, Nizzanim-A Neolithic site in Nahal Evtah: Excavations of 1968-1970: Tel Aviv, v 6, no. 3-4, p 99-135.

Yogev, Ora, 1983, A fifth millennium BCE sanctuary in the 'Uvda Valley: Qadmoniot, v 16 , no. 4, p 118-122.

Zeuner, F E, 1956, The radiocarbon age of Jericho: Antiquity, v 30, no. 120, p 195-197. 1960, Notes on Qumrân: Palestine Explor Quarterly, v 92, p 27-36.

\section{AdDendum}

Two items came to the author's attention too late to be included in the article above. (1) Fourteen new dates (Hel-1417 to -1424, Pta-3320, -3336, -3364, -3368 to -3370 ) from Middle and Late Bronze age and Iron age strata at Lachish have just appeared in print (Ussishkin, 1983, p 164-165, tables 2-3). (2) Based on conversations with other archaeologists and remarks made in several recent publications, it would appear that there are at present 35-40 unpublished ${ }^{14} \mathrm{C}$ dates. They come from at least 6 sites in Jordan, southern Israel, and Sinai and derive mostly from Neolithic and Chalcolithic contexts, though there are a few Epipalaeolithic and EB IV dates. 